\title{
Application of WRF/Chem-MADRID and WRF/Polyphemus in Europe - Part 2: Evaluation of chemical concentrations and sensitivity simulations
}

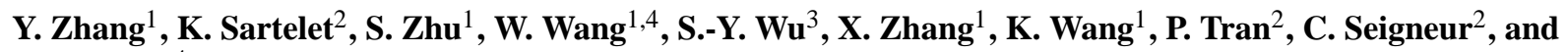 \\ Z.-F. Wang ${ }^{4}$ \\ ${ }^{1}$ Department of Marine, Earth, and Atmospheric Sciences, North Carolina State University, Raleigh, NC 27695, USA \\ ${ }^{2}$ CEREA (Atmospheric Environment Center), Joint Laboratory of École des Ponts ParisTech and EDF R\&D, Université \\ Paris-Est, 77455 Marne-la-Vallée, France \\ ${ }^{3}$ Department of Air Quality and Environmental Management, Clark County, NV, USA \\ ${ }^{4}$ Institute of Atmospheric Physics, Chinese Academy of Science, Beijing, China \\ Correspondence to: Y. Zhang (yzhang9@ncsu.edu)
}

Received: 12 December 2012 - Published in Atmos. Chem. Phys. Discuss.: 14 February 2013

Revised: 15 May 2013 - Accepted: 21 May 2013 - Published: 22 July 2013

\begin{abstract}
An offline-coupled model (WRF/Polyphemus) and an online-coupled model (WRF/Chem-MADRID) are applied to simulate air quality in July 2001 at horizontal grid resolutions of $0.5^{\circ}$ and $0.125^{\circ}$ over Western Europe. The model performance is evaluated against available surface and satellite observations. The two models simulate different concentrations in terms of domainwide performance statistics, spatial distribution, temporal variations, and column abundance. WRF/Chem-MADRID at $0.5^{\circ}$ gives higher values than WRF/Polyphemus for the domainwide mean and over polluted regions in Central and southern Europe for all surface concentrations and column variables except for the tropospheric ozone residual (TOR). Compared with observations, WRF/Polyphemus gives better statistical performance for daily $\mathrm{HNO}_{3}, \mathrm{SO}_{2}$, and $\mathrm{NO}_{2}$ at the European Monitoring and Evaluation Programme (EMEP) sites, maximum $1 \mathrm{~h}$ $\mathrm{O}_{3}$ at the AirBase sites, $\mathrm{PM}_{2.5}$ at the AirBase sites, maximum $8 \mathrm{~h} \mathrm{O}_{3}$ and $\mathrm{PM}_{10}$ composition at all sites, column abundance of $\mathrm{CO}, \mathrm{NO}_{2}$, TOR, and aerosol optical depth (AOD), whereas WRF/Chem-MADRID gives better statistical performance for $\mathrm{NH}_{3}$, hourly $\mathrm{SO}_{2}, \mathrm{NO}_{2}$, and $\mathrm{O}_{3}$ at the AirBase and BDQA (Base de données de la qualité de l'air) sites, maximum $1 \mathrm{~h} \mathrm{O}_{3}$ at the BDQA and EMEP sites, and $\mathrm{PM}_{10}$ at all sites. WRF/Chem-MADRID generally reproduces well the observed high hourly concentrations of $\mathrm{SO}_{2}$ and $\mathrm{NO}_{2}$ at most sites except for extremely high episodes at a few sites,
\end{abstract}

and WRF/Polyphemus performs well for hourly $\mathrm{SO}_{2}$ concentrations at most rural or background sites where pollutant levels are relatively low, but it underpredicts the observed hourly $\mathrm{NO}_{2}$ concentrations at most sites. Both models generally capture well the daytime maximum $8 \mathrm{~h} \mathrm{O}$ concentrations and diurnal variations of $\mathrm{O}_{3}$ with more accurate peak daytime and minimal nighttime values by WRF/Chem-MADRID, but neither model reproduces extremely low nighttime $\mathrm{O}_{3}$ concentrations at several urban and suburban sites due to underpredictions of $\mathrm{NO}_{\mathrm{x}}$ and thus insufficient titration of $\mathrm{O}_{3}$ at night. WRF/Polyphemus gives more accurate concentrations of $\mathrm{PM}_{2.5}$, and WRF/Chem-MADRID reproduces better the observations of $\mathrm{PM}_{10}$ concentrations at all sites. The differences between model predictions and observations are mostly caused by inaccurate representations of emissions of gaseous precursors and primary PM species, as well as biases in the meteorological predictions. The differences in model predictions are caused by differences in the heights of the first model layers and thickness of each layer that affect vertical distributions of emissions, model treatments such as dry/wet deposition, heterogeneous chemistry, and aerosol and cloud, as well as model inputs such as emissions of soil dust and sea salt and chemical boundary conditions of $\mathrm{CO}$ and $\mathrm{O}_{3}$ used in both models.

WRF/Chem-MADRID shows a higher sensitivity to grid resolution than WRF/Polyphemus at all sites. For both 
models, the use of a finer grid resolution generally leads to an overall better statistical performance for most variables, with greater spatial details and an overall better agreement in temporal variations and magnitudes at most sites. The use of online biogenic volatile organic compound (BVOC) emissions gives better statistical performance for hourly and maximum $8 \mathrm{~h} \mathrm{O}_{3}$ and $\mathrm{PM}_{2.5}$ and generally better agreement with their observed temporal variations at most sites. Because it is an online model, WRF/Chem-MADRID offers the advantage of accounting for various feedbacks between meteorology and chemical species. However, this model comparison suggests that atmospheric pollutant concentrations are most sensitive in state-of-the-science air quality models to vertical structure, inputs, and parameterizations for dry/wet removal of gases and particles in the model.

\section{Introduction}

Uncertainties in air quality modeling are high and exist in both offline- and online-coupled air quality models (AQMs). The uncertainties lie in model inputs such as meteorological fields, land use, emissions, and chemical initial and boundary conditions (ICs and BCs), model treatments such as inaccurate or missing atmospheric processes, as well as model simulation setup such as horizontal and vertical grid resolutions. In the framework of the Air Quality Model Evaluation International Initiative (AQMEII) project, Sartelet et al. (2012) found that for $\mathrm{O}_{3}, \mathrm{PM}_{2.5}$, and $\mathrm{PM}_{10}$ over Europe differences between the WRF/Polyphemus simulations using different anthropogenic or biogenic emission schemes are much smaller than the differences among the different AQMEII models. A number of studies examined which physical parameterizations, numerical approximations and boundary conditions affect pollutant concentrations the most over Europe (e.g., Pérez et al., 2006; Roustan et al., 2010). For example, Roustan et al. (2010) found that for most pollutants the modeling of the vertical diffusivity and the vertical resolution affects the simulated concentrations the most. However, the relative impact of the different parameterizations varies with the pollutants considered. Using the same model configuration, Real et al. (2011) found that the impact of aerosols on photolysis rates and, therefore, on gasphase chemistry and aerosol concentrations is also important. Differences in ozone $\left(\mathrm{O}_{3}\right)$ and PM concentrations were found to occur depending on the gas-phase chemical scheme (Kim et al., 2009, 2011). A number of studies examined the sensitivity of offline-coupled AQM predictions to horizontal grid resolutions. For example, Queen and Zhang (2008) found that the simulation at a fine grid resolution of $4 \mathrm{~km}$ better captured the mesoscale convection and thus predicted more accurate precipitation and wet deposition of chemical species in summer than the simulations at 12 or $36 \mathrm{~km}$ grid resolutions. Several studies, on the other hand, showed that a coarser grid resolution provided similar or even better air quality predictions than a finer grid resolution (Mathur et al., 2005; Arunachalam et al., 2006; Cohan et al., 2006; Zhang et al., 2006; Queen and Zhang, 2008; Liu et al., 2010). Bailey et al. (2007) and Valari and Menut (2008) found that model results do not improve monotonously with resolution. In all of these studies, meteorology is computed off-line, i.e., independently of the chemical transport model (CTM) calculation. It is assumed that there is no feedback between aerosol and meteorology.

Compared with offline-coupled models, the major advantage of the online-coupled meteorology and chemistry models is their capabilities to simulate not only pollutant concentrations but also aerosol direct and indirect feedbacks. For example, using WRF/Chem, Zhang et al. (2010) found that aerosols reduce incoming solar radiation by $-16 \%, 2 \mathrm{~m}$ temperatures by up to $0.37^{\circ} \mathrm{C}$, and daily precipitation by up to $19.4 \mathrm{~mm} \mathrm{day}^{-1}$ and lead to $500-5000 \mathrm{~cm}^{-3}$ cloud condensation nuclei $(\mathrm{CCN})$ at a supersaturation of $1 \%$ over most land areas in July over the continental US. Such feedbacks can change the abundance and lifetimes of chemical species such as $\mathrm{CO}, \mathrm{NO}_{2}, \mathrm{NH}_{3}$, and $\mathrm{O}_{3}$ through changing radiation, atmospheric stability, and the rates of many meteorologically dependent chemical and microphysical processes (Zhang et al., 2012a, b). Forkel et al. (2012) estimated the direct and indirect effects of aerosols on surface $\mathrm{O}_{3}$ and $\mathrm{PM}_{10}$ concentrations for June and July 2006 over Europe and found that the agreement between observed and simulated global radiation over Europe was better for cloudy conditions, and the monthly $\mathrm{PM}_{10}$ concentration increased by $1-3 \mu \mathrm{g} \mathrm{m}{ }^{-3}$ when the indirect effect was taken into account. Tuccella et al. (2012) reported significant underpredictions of sulfate by WRF/Chem without aerosol feedbacks and attributed this result to the missing aqueous-phase oxidation of $\mathrm{SO}_{2}$ by $\mathrm{H}_{2} \mathrm{O}_{2}$ and $\mathrm{O}_{3}$, a process that is not included in the standard configuration of WRF/Chem without aerosol-cloud feedbacks.

Similar to offline-coupled AQMs, online-coupled AQMs are subject to all aforementioned uncertainties and additional uncertainties in the meteorology-chemistry feedback mechanisms such as aerosol direct effects on radiation, photolysis rates, and planetary boundary layer (PBL) meteorology and indirect effects on cloud formation and precipitation through acting as cloud condensation nuclei $(\mathrm{CCN})$ and ice nuclei (IN). Furthermore, the uncertainties in those feedback mechanisms may be amplified by uncertainties in model inputs such as biogenic emissions and other model treatments such as gas-phase mechanisms, aerosol treatments, and cloud chemistry and microphysics, with latter uncertainties propagating into the former uncertainties through a sequence of chain effects. For example, Zhang et al. (2012a) applied an online-coupled WRF/Chem-MADRID model over the continental US and reported large differences in shortwave radiation and near-surface temperature and relative humidity at individual sites under cloudy conditions among the three simulations with three different gas-phase mechanisms. They 


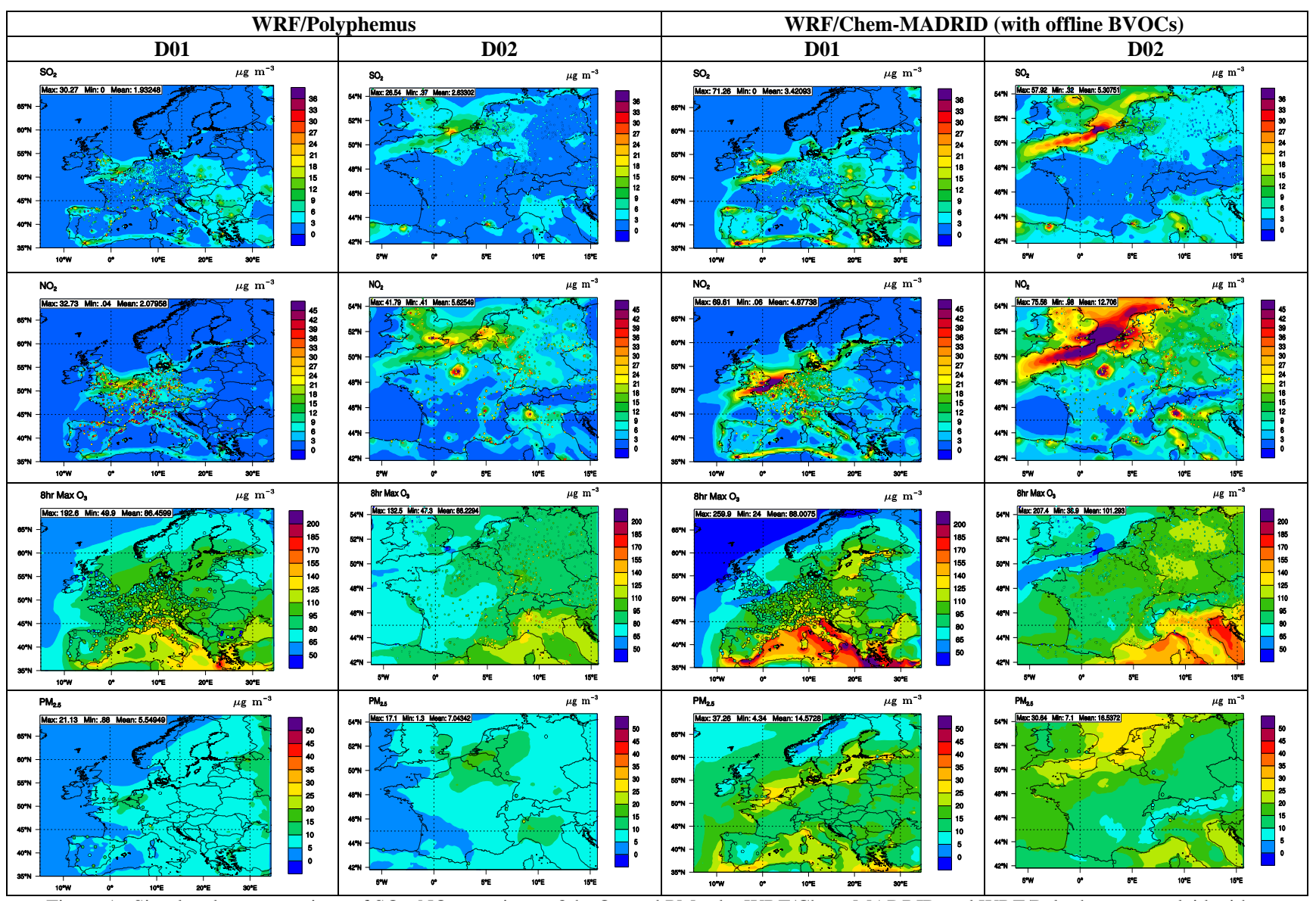

Fig. 1. Simulated concentrations of $\mathrm{SO}_{2}, \mathrm{NO}_{2}$, maximum $8 \mathrm{~h} \mathrm{O}$, and $\mathrm{PM}_{2.5}$ by WRF/Chem-MADRID and WRF/Polyphemus overlaid with observations in July 2001 over D01 and D02.

found that different gas-phase mechanisms lead to different aerosol mass and number concentrations, which in turn lead to different predictions of $\mathrm{CCN}$ and cloud droplet number concentration (CDNC) and cloud formation, and subsequently differences in shortwave radiation and PBL meteorology that are affected by cloud formation. These differences are caused by the sensitivity of the chain effects of feedback mechanisms among $\mathrm{H}_{2} \mathrm{SO}_{4}$ vapor, $\mathrm{PM}_{2.5}$ number, $\mathrm{CCN}$, and CDNC through gas-phase chemistry and new particle formation via homogeneous nucleation, aerosol growth, and aerosol activation by cloud droplets. The sensitivity of online-coupled air quality models to horizontal grid resolutions has also been studied (e.g., Misenis and Zhang, 2010; Wolke et al., 2012). For example, Wolke et al. (2012) found that the use of finer grid resolutions in their online-coupled model (i.e., COSMO-MUSCAT) can directly affect the meteorological predictions, and the calculated emission and deposition rates.

In this work, the simulations using the offline-coupled model (i.e., WRF/Polyphemus) and the online-coupled model (WRF/Chem-MADRID) are performed for July 2001 over double-nested domains: D01 and D02 as shown in Fig. 1 of Part 1 (Zhang et al., 2013), at horizontal grid resolutions of $0.5^{\circ}$ and $0.125^{\circ}$, respectively. Part 2 describes the evaluation and comparison of the chemical concentrations simulated by the two models, the sensitivity of chemical concentrations to horizontal grid resolutions for both models and to biogenic emissions for WRF/Chem-MADRID, as well as the effect of aerosol and meteorology interactions on air pollutant concentrations simulated using WRF/Chem-MADRID. The objectives are to evaluate the current offline- and onlinecoupled model capabilities of reproducing observations, to understand the most influential factors that cause differences in model predictions from both models, and to identify potential areas of model improvements. 
Table 1. Comparison of performance statistics of WRF/Polyphemus and WRF/Chem-MADRID over D01 ${ }^{1}$.

\begin{tabular}{|c|c|c|c|c|c|c|c|c|c|c|c|c|c|c|c|c|c|c|c|}
\hline \multirow[t]{2}{*}{ Variable } & \multirow[t]{2}{*}{ Network } & \multirow{2}{*}{$\begin{array}{r}\text { Data } \\
\text { pair }\end{array}$} & \multirow{2}{*}{$\begin{array}{l}\text { Mean } \\
\mathrm{Obs}^{2}\end{array}$} & \multicolumn{4}{|c|}{ Mean $\operatorname{Mod}^{2,3}$} & \multicolumn{4}{|c|}{$\mathrm{Corr}^{3}$} & \multicolumn{4}{|c|}{$\mathrm{NMB}^{3}(\%)$} & \multicolumn{4}{|c|}{$\mathrm{NME}^{3}(\%)$} \\
\hline & & & & WP & WC-S & WC-G & WC-M & WP & WC-S & WC-G & WC-M & WP & WC-S & WC-G & WC-M & WP & WC-S & WC-G & WC-M \\
\hline Hourly $\mathrm{NH}_{3}$ & AIRBASE & 5355 & 9.3 & 5.8 & 5.9 & 5.8 & 5.8 & 0.2 & 0.3 & 0.3 & 0.3 & -38.0 & -36.5 & -37.2 & -37.4 & 80.5 & 84.2 & 84.5 & 84.5 \\
\hline Daily $\mathrm{NH}_{3}$ & EMEP & 251 & 2.5 & 2.1 & 2.4 & 2.4 & 2.3 & 0.9 & 0.8 & 0.8 & 0.8 & -15.8 & -5.2 & -6.5 & -7.2 & 50.6 & 71.1 & 70.0 & 69.8 \\
\hline Daily $\mathrm{HNO}_{3}$ & EMEP & 250 & 0.5 & 1.3 & 1.5 & 2.0 & 2.3 & 0.4 & 0.4 & 0.4 & 0.4 & 135.9 & 175.9 & 277.2 & 323.4 & 161.1 & 207.0 & 300.3 & 344.0 \\
\hline \multirow{2}{*}{ Hourly $\mathrm{SO}_{2}$} & AIRBASE & 577595 & 5.1 & 3.5 & 5.9 & 5.8 & 5.8 & 0.2 & 0.2 & 0.2 & 0.2 & -30.4 & 16.5 & 14.7 & 15.1 & 72.9 & 93.1 & 92.2 & 92.5 \\
\hline & BDQA & 32073 & 5.3 & 3.4 & 5.6 & 5.5 & 5.5 & 0.2 & 0.2 & 0.2 & 0.2 & -36.1 & 6.4 & 4.9 & 5.4 & 81.2 & 98.9 & 98.4 & 98.5 \\
\hline Daily $\mathrm{SO}_{2}$ & EMEP & 1432 & 1.0 & 2.3 & 3.7 & 3.6 & 3.6 & 0.5 & 0.5 & 0.5 & 0.5 & 120.2 & 256.9 & 249.3 & 245.2 & 138.4 & 265.7 & 258.4 & 254.5 \\
\hline \multirow[t]{2}{*}{ Hourly $\mathrm{NO}_{2}$} & AIRBASE & 741439 & 17.4 & 7.6 & 14.6 & 14.5 & 14.5 & 0.3 & 0.3 & 0.3 & 0.3 & -56.2 & -15.7 & -16.4 & -16.8 & 70.3 & 72.5 & 71.9 & 72.2 \\
\hline & BDQA & 55326 & 15.9 & 7.2 & 13.5 & 13.2 & 13.1 & 0.2 & 0.2 & 0.2 & 0.2 & -54.7 & -15.4 & -17.0 & -17.6 & 75.3 & 81.9 & 82.2 & 82.2 \\
\hline Daily $\mathrm{NO}_{2}$ & EMEP & 1091 & 4.7 & 4.1 & 8.4 & 8.4 & 8.6 & 0.6 & 0.4 & 0.4 & 0.4 & -12.0 & 78.3 & 77.3 & 81.7 & 50.8 & 111.5 & 111.1 & 113. \\
\hline \multirow[t]{3}{*}{ Hourly $\mathrm{O}_{3}$} & AIRBASE & 779596 & 67.9 & 80.9 & 78.7 & 70.8 & 77.3 & 0.5 & 0.7 & 0.7 & 0.7 & 19.1 & 15.9 & 4.2 & 13.8 & 40.3 & 36.1 & 32.7 & 34.6 \\
\hline & BDQA & 97266 & 71.0 & 79.0 & 78.2 & 69.4 & 76.0 & 0.6 & 0.7 & 0.7 & 0.7 & 11.2 & 10.1 & -2.3 & 7.0 & 34.4 & 31.4 & 29.5 & 29. \\
\hline & EMEP & 82306 & 74.2 & 78.8 & 77.5 & 71.5 & 69.8 & 0.6 & 0.6 & 0.6 & 0.6 & 6.1 & 4.3 & -3.7 & -6.0 & 28.0 & 29.0 & 27.5 & 27.7 \\
\hline \multirow{3}{*}{$\operatorname{Max} 1-\mathrm{h} \mathrm{O}_{3}$} & AIRBASE & 33271 & 105.4 & 103.9 & 112.4 & 99.9 & 109.3 & 0.6 & 0.7 & 0.7 & 0.7 & -1.3 & 6.4 & -5.4 & 3.5 & 20.4 & 20.7 & 19.3 & 19. \\
\hline & BDQA & 4135 & 110.8 & 102.5 & 113.8 & 99.7 & 109.2 & 0.7 & 0.8 & 0.8 & 0.8 & -7.5 & 2.6 & -10.2 & -1.6 & 19.7 & 18.6 & 18.7 & $17 . C$ \\
\hline & EMEP & 3499 & 101.1 & 96.8 & 103.9 & 94.4 & 92.2 & 0.6 & 0.7 & 0.7 & 0.7 & -4.2 & 2.7 & -6.7 & -8.9 & 18.5 & 19.7 & 18.3 & 18.8 \\
\hline \multirow[t]{3}{*}{$\mathrm{Max} 8-\mathrm{h} \mathrm{O}_{3}$} & AIRBASE & 32730 & 94.8 & 99.9 & 104.8 & 93.2 & 102.1 & 0.6 & 0.7 & 0.7 & 0.7 & 5.6 & 10.5 & -1.7 & 7.7 & 21.6 & 22.2 & 19.5 & 20.3 \\
\hline & BDQA & 4080 & 99.8 & 98.2 & 105.9 & 92.8 & 101.8 & 0.7 & 0.8 & 0.8 & 0.8 & -1.6 & 6.1 & -7.0 & 2.0 & 18.8 & 19.1 & 18.0 & 17.1 \\
\hline & EMEP & 3433 & 92.7 & 93.3 & 97.1 & 88.5 & 86.5 & 0.6 & 0.7 & 0.7 & 0.7 & 0.6 & 4.9 & -4.4 & -6.6 & 18.8 & 20.0 & 18.1 & 18.4 \\
\hline Hourly $\mathrm{PM}_{2.5}$ & AIRBASE & 2618 & 12.1 & 11.3 & 25.3 & 21.1 & 21.4 & 0.5 & 0.4 & 0.4 & 0.5 & -7.0 & 109.4 & 74.7 & 77.4 & 42.6 & 125.6 & 94.3 & 94.8 \\
\hline \multirow{2}{*}{ Daily $\mathrm{PM}_{2.5}$} & AIRBASE & 110 & 12.0 & 11.2 & 25.6 & 21.3 & 21.6 & 0.7 & 0.5 & 0.7 & 0.7 & -7.4 & 112.7 & 77.0 & 79.6 & 29.7 & 115.5 & 81.5 & 82.7 \\
\hline & EMEP & 537 & 12.0 & 8.4 & 14.8 & 14.9 & 14.9 & 0.6 & 0.5 & 0.5 & 0.5 & -30.4 & 23.3 & 23.8 & 24.4 & 41.5 & 48.5 & 48.9 & 48.6 \\
\hline \multirow{2}{*}{ Hourly $\mathrm{PM}_{10}$} & AIRBASE & 214203 & 24.3 & 11.9 & 21.5 & 21.2 & 21.7 & 0.3 & 0.3 & 0.3 & 0.3 & -51.1 & -11.8 & -12.9 & -10.7 & 59.1 & 54.1 & 53.2 & 54.1 \\
\hline & BDQA & 22667 & 19.4 & 12.3 & 23.5 & 23.4 & 24.1 & 0.4 & 0.3 & 0.3 & 0.3 & -36.5 & 20.8 & 20.4 & 24.1 & 52.8 & 64.2 & 63.3 & 65.5 \\
\hline \multirow[t]{3}{*}{ Daily $\mathrm{PM}_{10}$} & AIRBASE & 9215 & 24.4 & 11.9 & 21.5 & 21.2 & 21.8 & 0.4 & 0.4 & 0.4 & 0.4 & -51.2 & -11.8 & -12.8 & -10.7 & 53.6 & 36.1 & 35.5 & 35. \\
\hline & BDQA & 997 & 19.0 & 12.2 & 23.2 & 23.1 & 23.8 & 0.5 & 0.5 & 0.5 & 0.5 & -36.2 & 24.9 & 24.6 & 28.3 & 42.9 & 46.7 & 45.7 & 47.6 \\
\hline & EMEP & 811 & 17.4 & 10.5 & 18.8 & 18.9 & 18.9 & 0.6 & 0.4 & 0.4 & 0.4 & -39.5 & 8.3 & 8.6 & 8.7 & 46.4 & 45.7 & 45.4 & 44. \\
\hline Daily $\mathrm{PM}_{10}$ & AIRBASE & 606 & 2.1 & 2.1 & 3.1 & 3.3 & 3.3 & 0.6 & 0.7 & 0.7 & 0.7 & 0.2 & 49.1 & 58.5 & 58.1 & 54.7 & 74.1 & 78.7 & 78.6 \\
\hline $\mathrm{SO}_{4}^{2-}$ & EMEP & 1570 & 2.7 & 2.2 & 3.7 & 4.1 & 4.2 & 0.6 & 0.6 & 0.6 & 0.6 & -16.0 & 39.0 & 52.1 & 58.4 & 44.5 & 59.6 & 67.9 & 72. \\
\hline Daily $\mathrm{PM}_{10}$ & AIRBASE & 271 & 2.7 & 3.7 & 8.5 & 8.4 & 8.7 & 0.8 & 0.7 & 0.7 & 0.7 & 37.2 & 214.4 & 211.4 & 221.7 & 58.2 & 220.7 & 217.5 & 227.0 \\
\hline $\mathrm{NO}_{3}^{-}$ & EMEP & 553 & 1.4 & 1.0 & 2.7 & 2.9 & 3.1 & 0.6 & 0.5 & 0.5 & 0.5 & -23.7 & 95.1 & 116.2 & 127.8 & 74.9 & 148.5 & 158.4 & 164.8 \\
\hline Daily $\mathrm{PM}_{10}$ & AIRBASE & 271 & 1.7 & 2.0 & 2.9 & 3.0 & 3.0 & 0.7 & 0.8 & 0.8 & 0.8 & 12.9 & 69.6 & 71.1 & 75.3 & 35.4 & 79.6 & 80.1 & 83.8 \\
\hline $\mathrm{NH}_{4}^{+}$ & EMEP & 449 & 1.1 & 1.0 & 1.3 & 1.5 & 1.5 & 0.7 & 0.7 & 0.7 & 0.7 & -4.4 & 21.9 & 36.1 & 42.7 & 46.9 & 65.9 & 69.9 & 73. \\
\hline Daily $\mathrm{PM}_{10} \mathrm{Na}^{+}$ & EMEP & 164 & 0.3 & 0.5 & 1.7 & 1.7 & 1.7 & 0.7 & 0.7 & 0.7 & 0.7 & 71.1 & 474.2 & 477.5 & 477.9 & 112.7 & 474.2 & 477.5 & 477. \\
\hline Daily $\mathrm{PM}_{10}$ & AIRBASE & 163 & 0.7 & 2.2 & 3.7 & 3.7 & 3.7 & 0.7 & 0.7 & 0.7 & 0.7 & 235.7 & 452.0 & 456.8 & 453.0 & 251.5 & 461.3 & 466.1 & 462.4 \\
\hline $\mathrm{Cl}^{-}$ & EMEP & 102 & 0.2 & 0.7 & 1.0 & 1.0 & 1.0 & 0.4 & 0.6 & 0.6 & 0.6 & 274.3 & 449.5 & 454.1 & 443.3 & 321.3 & 460.9 & 465.3 & 455. \\
\hline Column $\mathrm{CO}^{4}$ & MOPPIT & 4963 & 1.44 & 1.5 & 2.2 & 2.1 & 2.1 & 0.1 & 0.3 & 0.1 & 0.2 & 5.3 & 50.9 & 43.0 & 45.3 & 25.8 & 51.0 & 43.6 & 45.7 \\
\hline Column $\mathrm{NO}_{2}{ }^{4}$ & GOME & 5234 & 1.9 & 1.6 & 2.7 & 2.8 & 2.8 & 0.8 & 0.8 & 0.8 & 0.8 & -13.7 & 45.1 & 52.0 & 49.2 & 41.7 & 59.1 & 64.2 & 61. \\
\hline TOR & TOMS & 2160 & 43.7 & 55.5 & 30.3 & 30.1 & 30.5 & 0.6 & 0.7 & 0.7 & 0.7 & 26.8 & -30.6 & -31.2 & -30.2 & 26.8 & 30.6 & 31.2 & 30.2 \\
\hline AOD & MODIS & 5398 & 0.19 & 0.42 & 0.43 & 0.41 & 0.41 & 0.60 & 0.28 & 0.31 & 0.33 & 125.0 & 129.6 & 115.2 & 116.2 & 125.3 & 131.3 & 117.6 & 118.5 \\
\hline
\end{tabular}

${ }^{1}$ WP - WRF/Polyphemus; the WRF/Chem-MADRID simulations with three BVOC emissions include: WC-S - offline BVOC emissions of Simpson et al. (1999); WC-G - online Guenther et al. (1995); WC-M - onlineGuenther et al. (2006) (i.e., MEGAN);

2 unit of concentration is $\mu \mathrm{g} \mathrm{m}^{-3}$;

3 the best statistics among 4 runs is in green, corr - correlation coefficient, NMB - normalized mean bias, and NME - normalized mean error;

4 the column $\mathrm{CO}$ and $\mathrm{NO}_{2}$ abundance and tropospheric ozone residual (TOR) values are in $1 \times 10^{18} \mathrm{molec}^{-2}, 1 \times 10^{15} \mathrm{molec} \mathrm{cm}^{-2}$, and and Dobson unit (DU), respectively.

\section{Evaluation and intercomparison of WRF/Chem and WRF/Polyphemus}

\subsection{Spatial distribution and domainwide performance statistics}

Figures 1 and 2 show simulated spatial distributions of concentrations of $\mathrm{SO}_{2}, \mathrm{NO}_{2}$, maximum $8 \mathrm{~h} \mathrm{O}$, and $24 \mathrm{~h}$ average $\mathrm{PM}_{2.5}, \mathrm{PM}_{10}$, and major $\mathrm{PM}_{10}$ composition $\left(\mathrm{SO}_{4}^{2-}, \mathrm{NO}_{3}^{-}\right.$, $\mathrm{NH}_{4}^{+}$, and total organic matter (TOM)) by WRF/Polyphemus and WRF/Chem-MADRID overlaid with observations over D01 and D02 at horizontal grid resolutions of $0.5^{\circ}$ and $0.125^{\circ}$ in July 2001 . The corresponding domainwide performance statistics for those species and additional species such as $\mathrm{NH}_{3}, \mathrm{HNO}_{3}$, and other $\mathrm{PM}_{10}$ components $\left(\mathrm{Na}^{+}\right.$and $\left.\mathrm{Cl}^{-}\right)$ is shown in Table 1. The results over D01 are discussed below, and those over D02 are discussed in Sect. 3.1. The observed concentrations of $\mathrm{SO}_{2}, \mathrm{NO}_{2}, \mathrm{O}_{3}$, and $\mathrm{PM}_{2.5}$ are higher in several areas in Central and southern Europe than in northern Europe (i.e., the Nordic countries such as Denmark, Norway, Sweden, and Finland and Baltic countries such as Esto- nia, Latvia, and Lithuania) because of higher pollutant precursor concentrations and weather conditions that are more conducive to $\mathrm{O}_{3}$ and secondary $\mathrm{PM}_{2.5}$ production at these mid-latitudes. The spatial distributions of $\mathrm{SO}_{2}$ concentrations predicted by both models are overall similar and consistent with the spatial distribution of $\mathrm{SO}_{2}$ emissions inland and over shipping routes. WRF/Chem-MADRID predicts higher $\mathrm{SO}_{2}$ concentrations and greater gradients in several areas, including the English Channel, the shipping routes in the Mediterranean Sea off the south of Spain, Italy, and Greece, the northwestern corner of Spain, and the southern portions of Poland, Romania, and Bulgaria. Spatially, WRF/ChemMADRID also predicts higher $\mathrm{NO}_{2}$ concentrations in larger areas, particularly over areas with high $\mathrm{NO}_{2}$ emissions, including the English Channel and southern UK, northern France, northern Italy, Germany, Belgium, the Netherlands, Denmark, the Baltic Sea areas off the coast of Sweden, as well as the shipping routes in the Mediterranean Sea. Differences in $\mathrm{SO}_{2}$ and $\mathrm{NO}_{2}$ concentrations predicted by both models are likely caused by several factors, including differences in heights in the first model layer and the thickness 


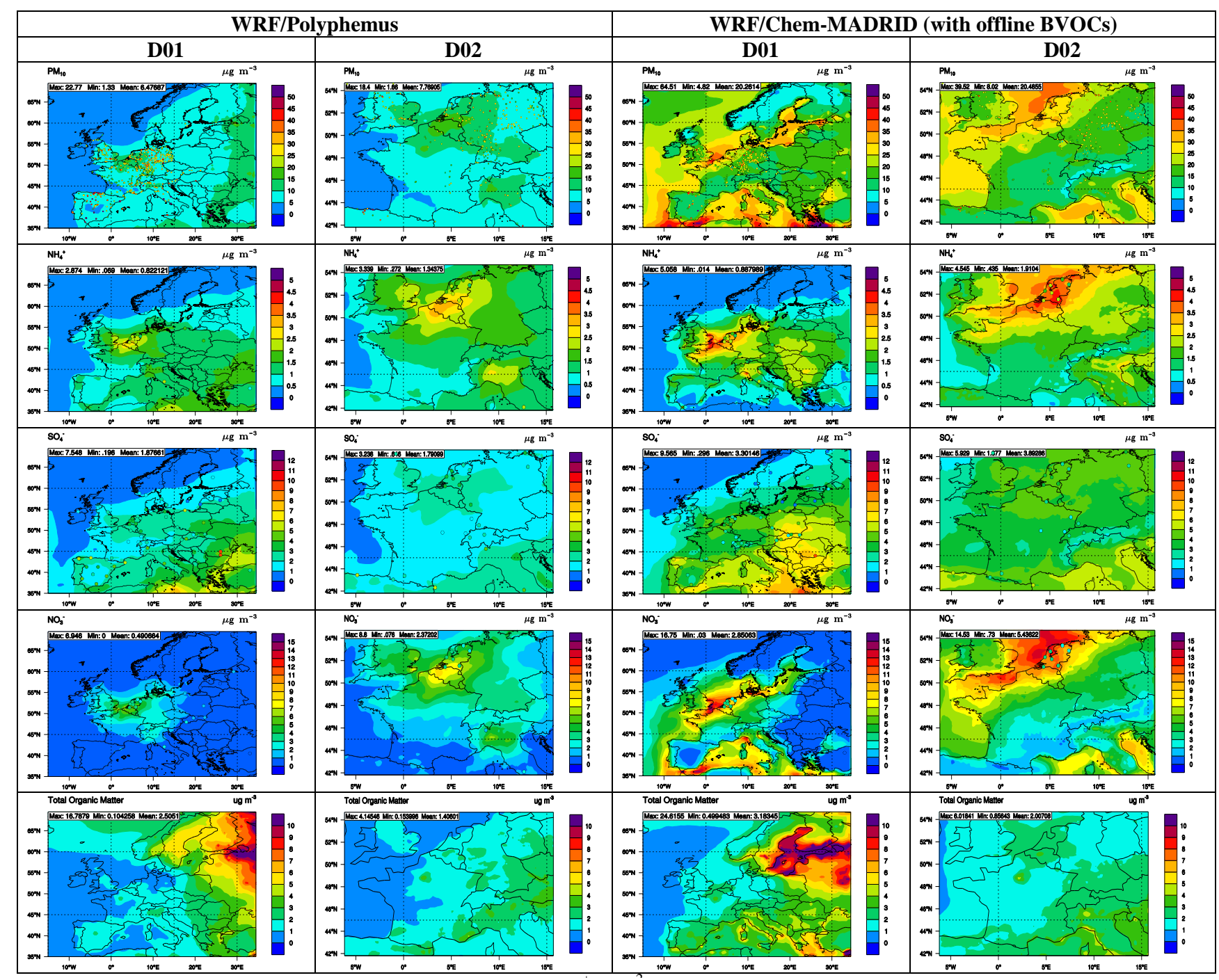

Fig. 2. Simulated concentrations of $\mathrm{PM}_{10}$ and its components, $\mathrm{NH}_{4+}, \mathrm{SO}_{4}^{2-}, \mathrm{NO}_{3-}$, and organic matter (OM) by WRF/Polyphemus and WRF/Chem-MADRID overlaid with observations in July 2001 over D01 and D02. No observations were available for OM.

of each layer, that affect the vertical distributions of emissions, dry and wet deposition treatments, and aerosol treatments as described in Part 1 (Zhang et al., 2013). Given the same surface emissions, lower heights in the first model layer in WRF/Chem can lead to higher surface concentrations. Different thickness of each layer in both models can also lead to differences in concentrations in the surface and upper layers. Compared with WRF/Polyphemus, WRF/ChemMADRID gives much lower dry deposition fluxes for gases (see Part 1, Zhang et al., 2013), leading to higher concentrations of $\mathrm{SO}_{2}, \mathrm{NO}_{\mathrm{x}}$, and other gaseous species such as $\mathrm{NH}_{3}, \mathrm{HNO}_{3}, \mathrm{O}_{3}$, and $\mathrm{OH}$ radicals. Consequently, the levels of those gaseous precursors for aerosol thermodynamic partitioning and the levels of aqueous-phase oxidants such as $\mathrm{O}_{3}$ and $\mathrm{H}_{2} \mathrm{O}_{2}$ for aqueous-phase formation of secondary aerosols are also higher in WRF/Chem-MADRID, leading to higher production of $\mathrm{SO}_{4}^{2-}, \mathrm{NO}_{3}^{-}$, and $\mathrm{NH}_{4}^{+}$. Further, homogeneous binary nucleation of sulfuric acid $\left(\mathrm{H}_{2} \mathrm{SO}_{4}\right)$ and water vapor $\left(\mathrm{H}_{2} \mathrm{O}\right)$ and aerosol thermodynamics of $\mathrm{Na}^{+}$and $\mathrm{Cl}^{-}$are treated in WRF/Chem-MADRID, but not treated in WRF/Polyphemus. As a result of nucleation treatments, WRF/Chem-MADRID gives higher PM number concentrations and cloud droplet number concentrations, which can enhance cloud formation and thus aqueous-phase formation of $\mathrm{SO}_{4}^{2-}$. Inclusion of $\mathrm{Na}^{+}$and $\mathrm{Cl}^{-}$in aerosol thermodynamics calculations in WRF/Chem-MADRID may enhance the formation of $\mathrm{NO}_{3}^{-}$. The heterogeneous reactions of $\mathrm{NO}_{3}$ and $\mathrm{N}_{2} \mathrm{O}_{5}$ treated in WRF/Polyphemus provide additional pathways to remove reactive nitrogen, therefore decreasing $\mathrm{NO}_{2}$ and increasing $\mathrm{NO}_{3}^{-}$in the particulate phase, as shown by Roustan et al. (2010). Such different treatments help explain in part lower concentrations of $\mathrm{NO}_{2}$ predicted by 
WRF/Polyphemus than by WRF/Chem-MADRID. For domainwide performance statistics, WRF/Polyphemus underpredicts observed $\mathrm{SO}_{2}$ concentrations at the AirBase and BDQA (Base de données de la qualité de l'air) sites with normalized mean biases (NMBs) of $-30.4 \%$ and $-36.1 \%$, respectively, and overpredicts those at the European Monitoring and Evaluation Programme (EMEP) sites with an NMB of $120.2 \%$, whereas WRF/Chem-MADRID overpredicts observations at all sites, particularly at the EMEP sites with an NMB of $256.9 \%$. WRF/Polyphemus also underpredicts observed $\mathrm{NO}_{2}$ concentrations, particularly at the AirBase and BDQA sites, with NMBs of $-56.2 \%$ and $-54.7 \%$, respectively. WRF/Chem-MADRID performs much better over the AirBase and BDQA sites with NMBs of $-15.7 \%$ and $-15.4 \%$, respectively. However, it significantly overpredicts those at the EMEP sites with an NMB of $78.3 \%$. Uncertainties in the EMEP emissions of $\mathrm{SO}_{2}$ and $\mathrm{NO}_{\mathrm{x}}$ in terms of total amount and spatial and vertical distributions as reported in several studies (e.g., de Meij et al., 2006; Mallet and Sportisse, 2006) may contribute to the discrepancies between observations and predictions by both models. For example, $50 \%$ of $\mathrm{SO}_{2}$ and $\mathrm{NO}_{2}$ emissions in the EMEP inventories are assumed to be emitted at $\sim 150 \mathrm{~m}$ (de Meij et al., 2006), which may explain in part the underpredictions in surface concentrations of $\mathrm{NO}_{2}$ by both models and in those of $\mathrm{SO}_{2}$ by Polyphemus. The EMEP sites are mostly rural background sites, and the AirBase and BDQA sites also include suburban and urban background sites. WRF/Polyphemus tends to perform better for $\mathrm{SO}_{2}$ and $\mathrm{NO}_{2}$ at rural sites, while WRF/Chem-MADRID tends to perform better at suburban and urban background sites.

For maximum $1 \mathrm{~h} \mathrm{O}$, WRF/Chem-MADRID performs better than WRF/Polyphemus, with small overpredictions against AirBase and small to moderate underpredictions against BDQA and EMEP. For maximum $8 \mathrm{~h} \mathrm{O}$, WRF/Polyphemus slightly underpredicts with NMBs of $-1.6 \%$ to $5.6 \%$, and WRF/Chem-MADRID slightly overpredicts with NMBs of $4.9-10.5 \%$ at all sites. The differences between the predicted $\mathrm{O}_{3}$ concentrations by the two models may be mainly explained by the differences in dry deposition treatments used in both models (as described in Part 1). Compared with WRF/Chem-MADRID, WRF/Polyphemus gives higher dry deposition fluxes for $\mathrm{O}_{3}$, leading to lower $\mathrm{O}_{3}$ concentrations. Spatially, both models predict much larger concentrations of maximum $8 \mathrm{~h} \mathrm{O}_{3}$ (see Fig. 1) and maximum $1 \mathrm{~h} \mathrm{O}_{3}$ (figure not shown but very similar to those for maximum $8 \mathrm{~h} \mathrm{O}_{3}$ ) in the Mediterranean Sea, Italy, Greece, and Turkey $\left(>110 \mu \mathrm{g} \mathrm{m}^{-3}\right)$, with larger magnitudes, and in several additional areas such as the Baltic Sea, central Poland, and western Hungary by WRF/ChemMADRID due to lower dry deposition fluxes of $\mathrm{O}_{3}$ and its precursor gases. These high $\mathrm{O}_{3}$ concentrations are caused by high pollutant precursors and the summer weather conditions that favor the formation of $\mathrm{O}_{3}$. Despite overpredictions, both models predict enhanced near-surface $\mathrm{O}_{3}$ concen- trations in southern Sweden and Finland, and Baltic Europe, consistent with observed historic $\mathrm{O}_{3}$ trends reported by Engardt et al. (2009). The elevated $\mathrm{O}_{3}$ levels reflect the advection of $\mathrm{O}_{3}$-laden air from continental Europe after periods of $\mathrm{O}_{3}$ buildup.

For $\mathrm{PM}_{2.5}$ concentrations, WRF/Polyphemus moderately underpredicts them with NMBs of $-30.4 \%$ and $-7.4 \%$ at the EMEP and AirBase sites (in particular over Spain), respectively, for daily concentrations and $-7.0 \%$ at the EMEP sites for hourly concentrations. WRF/Chem-MADRID significantly overpredicts hourly and daily $\mathrm{PM}_{2.5}$ concentrations at the AirBase sites with NMBs of $109.4 \%$ and $112.7 \%$ and moderately overpredicts daily $\mathrm{PM}_{2.5}$ concentrations with an NMB of $23.3 \%$. Spatially, WRF/Chem-MADRID generates much higher $\mathrm{PM}_{2.5}$ concentrations over the whole domain than WRF/Polyphemus, with domain-average values of 14.6 and $5.5 \mu \mathrm{g} \mathrm{m}^{-3}$, respectively. The highest $\mathrm{PM}_{2.5}$ concentrations are predicted along the shipping routes in the Mediterranean Sea, the English Channel, and the Baltic Sea. Similarly to $\mathrm{O}_{3}$ predictions, both models predict enhanced levels of $\mathrm{PM}_{2.5}$ in the Nordic and Baltic countries, reflecting the impact of long-range transport of $\mathrm{PM}_{2.5}$ and its precursors from Central Europe to this region. For $\mathrm{PM}_{10}$ concentrations, WRF/Polyphemus significantly underpredicts them at all sites (in particular over Spain) with NMBs of -51.2 to $-36.2 \%$. WRF/Chem-MADRID performs better with NMBs of $-11.8 \%$ to $24.9 \%$ for daily concentrations and $-11.8 \%$ to $20.8 \%$ for hourly concentrations, mainly because of the overprediction of $\mathrm{PM}_{2.5}$ and sea-salt concentrations as well as the inclusion of mineral dust emissions. The spatial distributions of $\mathrm{PM}_{10}$ concentrations are overall similar to those of $\mathrm{PM}_{2.5}$ concentrations in both models. Similar to $\mathrm{PM}_{2.5}$ concentrations, WRF/Chem-MADRID predicts three times higher $\mathrm{PM}_{10}$ concentrations over the whole domain than WRF/Polyphemus, with domain-average values of 20.3 and $6.5 \mu \mathrm{g} \mathrm{m}^{-3}$, respectively, and the highest concentrations along the shipping routes. The domainwide mean concentrations of coarse PM (i.e., $\mathrm{PM}_{10-2.5}$ ) are $1 \mu \mathrm{g} \mathrm{m}^{-3}$ for WRF/Polyphemus and $5.7 \mu \mathrm{g} \mathrm{m}^{-3}$ for WRF/ChemMADRID over D01. WRF/Chem-MADRID predicts higher $\mathrm{PM}_{10-2.5}$ concentrations than WRF/Polyphemus due to the online generation of mineral dust emissions from land types that can possibly emit dust particles such as shrubland, barren, or sparsely vegetated land and sea-salt emissions that are higher than offline sea-salt emissions used in WRF/Polyphemus. Differences in natural emissions of sea salt and mineral dust may also contribute to differences in predicted $\mathrm{PM}_{2.5}$ concentrations, as a small portion of those emissions are in the size range of $\mathrm{PM}_{2.5}$. Although dust particle emissions from the Sahara desert are not explicitly simulated because the simulation domain does not cover Sahara desert, WRF/Chem-MADRID uses chemical BCs from the global-through-urban WRF/Chem (GU-WRF/Chem) of Zhang et al. (2012b), which simulates mineral dust emissions from all dust source regions including the Sahara desert, 
and it also simulates soil dust emissions from the aforementioned land types within the simulation domain. The enhanced $\mathrm{PM}_{10}$ concentrations simulated by WRF/ChemMADRID are consistent with several studies that accounted for contributions of mineral dust to $\mathrm{PM}_{10}$ (e.g., JiménezGuerrero et al., 2008). In WRF/Polyphemus, $\mathrm{PM}_{10-2.5}$ results primarily from the offline sea-salt emissions. Although the Goddard Chemistry Aerosol Radiation and Transport (GOCART, Chin et al., 2000) also accounted for the contributions of Saharan dust, those values represented high dust events and were unrealistically high. They were divided by 4 to represent the boundary conditions of coarse PM in WRF/Polyphemus following Sartelet et al. (2007), resulting in small differences between simulated $\mathrm{PM}_{10}$ and $\mathrm{PM}_{2.5}$ concentrations over southern Europe.

In addition to higher dust and sea-salt concentrations, higher concentrations of secondary inorganic aerosols such as $\mathrm{NH}_{4}^{+}, \mathrm{SO}_{4}^{2-}$, and $\mathrm{NO}_{3}^{-}$, secondary organic aerosols (SOAs), and primary PM (e.g., elemental carbon (EC), primary organic carbon (POC), dust, and sea salt) contribute to higher $\mathrm{PM}_{2.5}$ and $\mathrm{PM}_{10}$ concentrations by WRF/ChemMADRID. Those higher concentrations result from the differences in heights of the first model layers and thickness of each layer, which affects the vertical distributions of emissions of primary PM and gaseous precursors of secondary PM as mentioned previously and in model treatments including dry and wet depositions of $\mathrm{PM}_{2.5}$ and $\mathrm{PM}_{10}$ compositions, inorganic aerosol thermodynamics, heterogeneous chemistry, SOA, and aerosol-cloud interactions. For example, compared with WRF/Polyphemus, WRF/ChemMADRID may estimate lower dry deposition velocities and lower wet scavenging coefficients for PM species, leading to higher PM concentrations. WRF/Chem-MADRID overpredicts the concentrations of secondary inorganic aerosol species, whereas to a lesser extent WRF/Polyphemus either underpredicts (e.g., $\mathrm{SO}_{4}^{2-}$ and $\mathrm{NO}_{3}^{-}$at the EMEP sites) or overpredicts (e.g., $\mathrm{Na}^{+}$and $\mathrm{Cl}^{-}$at all sites and $\mathrm{NH}_{4}^{+}$and $\mathrm{NO}_{3}^{-}$at the AirBase sites). For example, the $\mathrm{NMBs}$ of $\mathrm{SO}_{4}^{2-}$ concentrations are $-16.0 \%$ to $0.2 \%$ for WRF/Polyphemus and $39.0 \%$ to $49.1 \%$ for WRF/ChemMADRID. At the EMEP sites, small to moderate underpredictions occur in the $\mathrm{NH}_{3}$ concentrations with an $\mathrm{NMB}$ of $-15.8 \%$ for WRF/Polyphemus and $-5.2 \%$ for WRF/ChemMADRID. The $\mathrm{HNO}_{3}$ concentrations are significantly overpredicted (with NMBs of $135.9 \%$ for WRF/Polyphemus and $175.9 \%$ for WRF/Chem-MADRID). Those model biases contribute to biases in the simulated concentrations of $\mathrm{NH}_{4}^{+}$and $\mathrm{NO}_{3}^{-}$, with a small to moderate underprediction (with NMBs of $-4.4 \%$ and $-23.7 \%$, respectively) by WRF/Polyphemus and the moderate to large overpredictions (with NMBs of $21.9 \%$ and $95.1 \%$, respectively) by WRF/Chem-MADRID. At the AirBase sites, larger underpredictions occur in the $\mathrm{NH}_{3}$ concentrations with NMBs of $-38.0 \%$ for WRF/Polyphemus and $-36.5 \%$ for
WRF/Chem-MADRID. Although there are no observational data for $\mathrm{HNO}_{3}$ from AirBase, moderate to large overpredictions of $\mathrm{NH}_{4}^{+}$and $\mathrm{NO}_{3}^{-}$concentrations (NMBs of $12.9 \%$ and $37.2 \%$ for WRF/Polyphemus and $69.6 \%$ and $214.4 \%$ for WRF/Chem-MADRID, respectively) imply an overprediction of $\mathrm{HNO}_{3}$ concentrations. They also indicate a $\mathrm{NH}_{4}^{+}$rich environment in which ammonium nitrate $\left(\mathrm{NH}_{4} \mathrm{NO}_{3}\right)$ formation is limited by the formation of $\mathrm{HNO}_{3}$ in the simulation domain, which is consistent with the findings of Sartelet et al. (2007). Both models predict high concentrations of SOA (thus TOM) over regions with high isoprene and terpene emissions, such as the northeastern portion of the domain, which dominates the concentrations of TOM. WRF/Chem-MADRID also predicts high concentrations of SOA in the southern portion of the domain where biogenic volatile organic compound (VOC) emissions are also high. WRF/Chem-MADRID gives a higher domain-averaged TOM concentration than WRF/Polyphemus due to higher gaseous oxidant levels and differences in the SOA treatments in both models. Note that no observations for SOA and TOM are available for evaluation.

\section{Evaluation of temporal variations at specific sites}

\subsection{Description of selected sites}

A total of 16 and 21 sites have been selected from 3 observational databases (AirBase, EMEP, and BDQA) for detailed temporal analyses of chemical predictions of gaseous (e.g., $\mathrm{SO}_{2}, \mathrm{NO}_{2}$, and $\mathrm{O}_{3}$ ) and $\mathrm{PM}$ (e.g., $\mathrm{PM}_{2.5}$ and $\mathrm{PM}_{10}$ ) pollutants, respectively. These sites and their characteristics are summarized in Table 3. Among the 16 sites selected for analyses of $\mathrm{SO}_{2}, \mathrm{NO}_{2}$, and $\mathrm{O}_{3}, 8$ sites (Melun, Nord-Est Alsace, and Sommet Puy-de-Dôme, France; Deuselbach, Germany; Ispra, Italy; Celje, Slovenia; Harwell, UK; and Avenida Gasteiz, Spain) are in D02, and 8 sites (Rörvik, Femman, and Södermalm, Sweden; Birkenes, Norway; Topolniky, Slovakia; Beato, Custóias, and Ermesinde, Portugal) are in D01 but outside D02. Among the 21 sites selected for analysis of $\mathrm{PM}_{2.5}$ and $\mathrm{PM}_{10}, 13$ sites (Tremblay-en-France and Ternay, France; Deuselbach and Langenbrugge, Germany; Payerne and Chaumont, Switzerland; Ispra, Italy; Celje, Slovenia; Harwell, Rochester Stoke, and London Bloomsbury, UK; and Cabo de Creus and Niembro, Spain) are in D02, and 8 sites (Celje, Slovenia; Sundsvall and Södermalm, Sweden; Birkenes, Norway; Mansikkala and Kallio_2, Finland; Illmitz, Austria; Ermesinde, Portugal) are in D01 but outside D02. Because of a lack of concurrent measurements of gaseous and PM concentrations at the same or colocated sites, the sites selected for gaseous and PM measurements are mostly different. Among the 32 sites selected, only 7 sites are common to both gaseous and PM measurements including Deuselbach, Ispra, Celje, Harwell, Södermalm, Birkenes, and Ermesinde. Only 6 sites are co- 

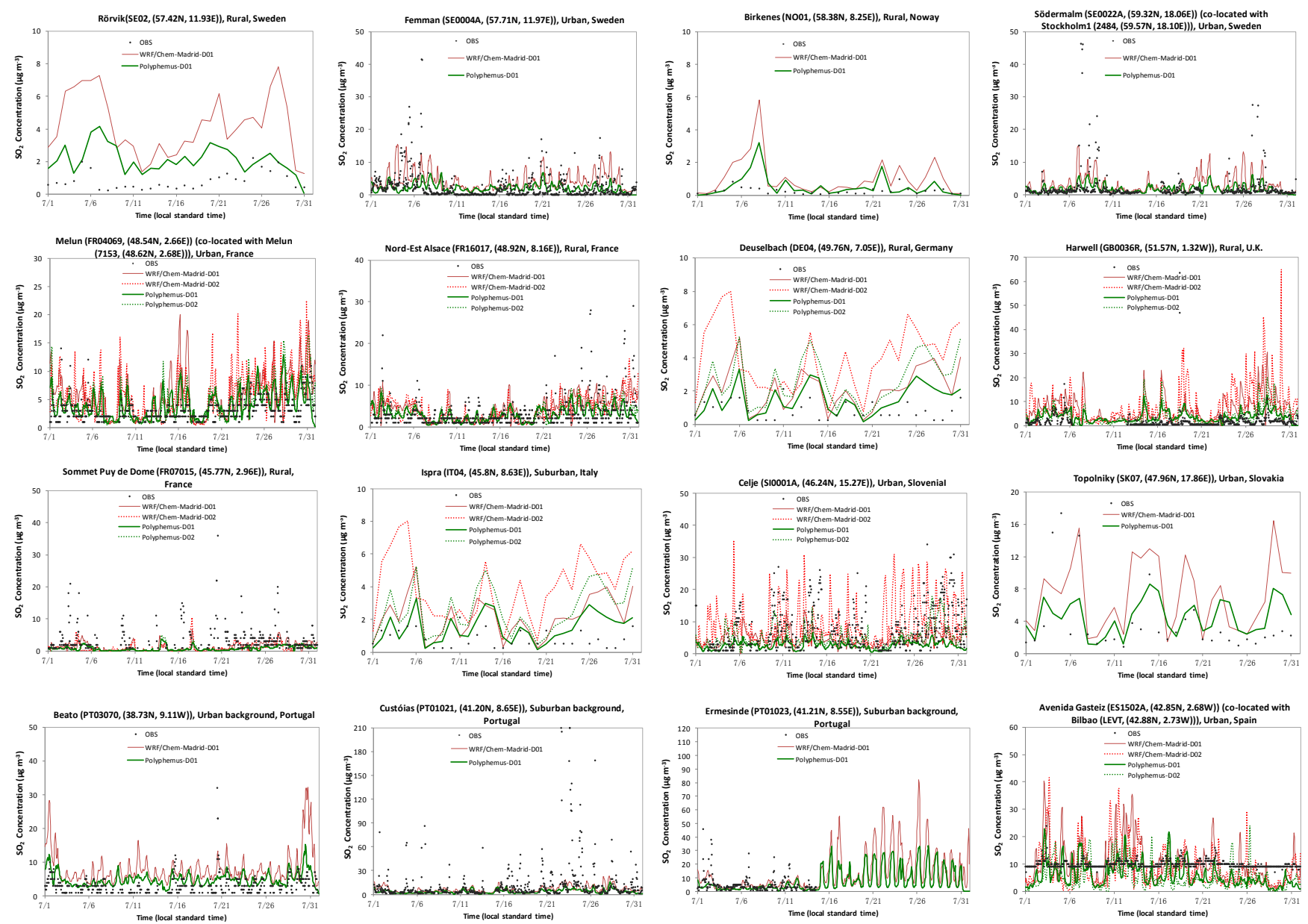

Fig. 3. Simulated and observed hourly or daily concentrations of $\mathrm{SO}_{2}$ in July 2001 at selected sites over D01 and D02 in four latitude bands: $57-60^{\circ} \mathrm{N}, 48-52^{\circ} \mathrm{N}, 45-48^{\circ} \mathrm{N}$, and $38-43^{\circ} \mathrm{N}$ (rows $1,2,3$, and 4 , respectively).

located with the selected meteorological sites from the NCEP or the ECA\&D databases (see Table 5 in Part 1) including 2 AirBase/BDQA sites (Melun and Tremblay-en-France) in France and 4 AirBase sites (Düsseldorf-Lörick in Germany, Avenida Gasteiz in Spain, Södermalm in Sweden, and London Bloomsbury in the UK). Melun (FR04069) is co-located with the NCEP site (Melun, 7153) and the ECA\&D site (Brétigny-sur-Orge, 000764). Tremblay-enFrance (FR04319) is co-located with the NCEP site (Charles de Gaulle, 7157). Düsseldorf-Lörick is co-located with the NCEP site (Düsseldorf 1 (10400)/Düsseldorf 210400 (EDDL)). Avenida Gasteiz (ES1502A) is co-located with the NCEP site Bilbao (LEVT). Södermalm (SE0022A) is co-located with the NCEP site Stockholm 1 (02484) and the ECA\&D site Stockholm (000010). London Bloomsbury (GB0566A) in the UK is co-located with the NCEP sites London 1 (3779) and London 2 (3781).

These sites are selected from 14 countries for their geographical and topographical representations. They are classified into 6 urban sites (Melun, Topolniky, Celje, Avenida
Gasteiz, Femman, Södermalm), 4 suburban sites (Ternay, Tremblay-en-France, Ispra, Payerne), 13 rural sites (Keldsnor, Nord-Est Alsace, Sommet Puy-de-Dôme, Deuselbach, Langenbrugge, Birkenes, Cabo de Creus, Els Torms, Niembro, Rörvik, Chaumont, Harwell, and Rochester Stoke), and 9 background sites (Illmitz, Mansikkala, Kallio_2, Sundsvall, London Bloomsbury, Düsseldorf-Lörick, Beato, Custóias, and Ermesinde). Among those background sites, 1 is a rural background site (Illmitz), 4 are urban background sites (Kallio_2, London Bloomsbury, Beato, and Sundsvall), and the remaining 4 are suburban background sites. Among all sites, there are 8 sites located $200 \mathrm{~m}$ above sea level (ASL), including Sommet Puy-de-Dôme $(1460 \mathrm{~m})$, Chaumont $(1130 \mathrm{~m})$, Avenida Gasteiz $(517 \mathrm{~m})$, Payerne (510 m), Deuselbach (480 m), Celje ( $240 \mathrm{~m}$ ), Ternay $(235 \mathrm{~m})$, and Ispra $(209 \mathrm{~m})$. The altitude, location, and topography affect the climatic conditions at all selected sites. Climatic conditions at these selected sites include Western European oceanic climate (i.e., Melun, Nord-Est Alsace, Sommet Puy-de-Dôme, Ternay, and Tremblay-en-France, 
France; Harwell, Rochester Stoke, and London Bloomsbury, UK; Avenida Gasteiz and Niembro, Spain; Illmitz, Austria; Deuselbach and Langenbrugge, Germany; Ispra, Italy; Birkenes, Norway; Rörvik and Femman, Sweden; and Payerne, Switzerland), continental or subtropical Mediterranean climate (Cabo de Creus, Spain; Beato, Custóias, and Ermesinde, Portugal), humid continental climate (Kallio, Finland; Södermalm, Sweden; and Chaumont, Switzerland), warm temperate climate (e.g., Keldsnor, Denmark; Topolniky, Slovakia; Celje, Slovenia), and subarctic climate (Mansikkala, Finland), borderline between oceanic and humid subtropical climate (Ternay, France), and borderline between subarctic and cold continental climate (Sundsvall, Sweden). Similar to the site selection for meteorological evaluation in Part 1, in addition to the representativeness of those sites in terms of climatic, geographical, and topographical characteristics, chemical data availability and completeness are also part of the consideration for site selections.

\subsubsection{Simulations over D01 at a horizontal grid resolution of $0.5^{\circ}$}

Figure 3 shows simulated and observed hourly concentrations of $\mathrm{SO}_{2}$ at 16 selected sites in four latitude bands: 57$60^{\circ} \mathrm{N}, 48-52^{\circ} \mathrm{N}, 45-48^{\circ} \mathrm{N}$, and $38-43^{\circ} \mathrm{N}$. The model performance varies with locations substantially. In the northern latitude band $\left(57-60^{\circ} \mathrm{N}\right)$, both models overpredict the concentrations of $\mathrm{SO}_{2}$ on a typical day but fail to reproduce the observed extremely high concentrations of $\mathrm{SO}_{2}$ during several pollution episodes at 2 urban sites in Sweden: Femman on 4-6, 20, and 27 July and Södermalm on 7-9 and 26-28 July, with much better agreement on high $\mathrm{SO}_{2}$ concentrations by WRF/Chem-MADRID than WRF/Polyphemus. Femman is a roof site in Gothenburg, the second largest city in southwestern Sweden. The Gothenburg area is known to have relatively limited dispersion due to complex terrain (i.e., valleys carved down into a flat plateau and its proximity to the sea). This topography favors the development of stable air and inversions inside the valleys (Haeger-Eugensson et al., 2010). The special topography and the stable, low wind meteorological conditions, coupled with high emissions of $\mathrm{SO}_{2}$, lead to extremely high $\mathrm{SO}_{2}$ episodes on some days in the Gothenburg area. Södermalm is located in central Stockholm on the south-central east coast of Sweden. Stockholm is the capital and the largest city of Sweden and constitutes the most populated urban area in Scandinavia. The topography of Stockholm is relatively smooth, without dominating ridges or valleys. However, Stockholm has a hemiboreal humid continental climate featuring a warm to hot summer. The wind speeds in Stockholm are typically low (mostly $<4 \mathrm{~m} \mathrm{~s}^{-1}$ ) (see Fig. 13 in Part 1). The hot, humid, and low wind summer coupled with high emissions favors the accumulation of air pollutants such as $\mathrm{SO}_{2}$ in Stockholm. As shown in Figures 9, 13, and 15 in Part 1, WRF captures well the meteorological conditions in Stockholm.
The failure of reproducing the extremely high $\mathrm{SO}_{2}$ by both models at Södermalm and Femman is primarily caused by the missing of the episodic emissions during a few days. WRF/Chem-MADRID gives much higher $\mathrm{SO}_{2}$ concentrations than WRF/Polyphemus for the reasons mentioned previously. At the 2 rural sites Rörvik, Sweden and Birkenes, Norway, both models significantly overpredict, with better agreement by WRF/Polyphemus. In the central latitude band $\left(48-52^{\circ} \mathrm{N}\right)$, both models overpredict at the urban site Melun and the rural site Nord-Est Alsace in France with better agreement by WRF/Polyphemus with observed low and average concentrations on most days and by WRF/ChemMADRID with observed high concentrations (e.g., during 2-5 July at Melun and during 2, 6, 21, 25-26, and 30-31 July at Nord-Est Alsace). As shown in Fig. 12 in Part 1, wind speeds are significantly underpredicted at Melun, which may explain in part the overpredictions in the $\mathrm{SO}_{2}$ concentrations at Melun due to underestimated dispersion. At the other 2 rural sites (Deuselbach, Germany, and Harwell, UK), both models significantly overpredict $\mathrm{SO}_{2}$ concentrations, with fewer overpredictions by WRF/Polyphemus. In the central south latitude band $\left(45-48^{\circ} \mathrm{N}\right)$, while large overpredictions by both models occur at an urban site (Topolniky, Slovakia) and a suburban site (Ispra, Italy), underpredictions occur at a rural mountain site (Sommet Puy-de-Dôme) on the top of the Puy-de-Dôme, a large lava dome and extinct volcano in south-central France where observed $\mathrm{SO}_{2}$ concentrations are typically high $\left(>5 \mu \mathrm{g} \mathrm{m}^{-3}\right)$ and can reach $36 \mu \mathrm{g} \mathrm{m}^{-3}$ due to regional emissions from industrial sources. At the urban site Celje in Slovenia where observed $\mathrm{SO}_{2}$ concentrations are high (mostly in the range of $5-34 \mu \mathrm{g} \mathrm{m}^{-3}$ ), while WRF/Polyphemus underpredicts, WRF/Chem-MADRID reproduces well the observed high $\mathrm{SO}_{2}$ concentrations. Celje has a climate that is in a transition between continental and alpine influenced by urban heat island. It is located in a basin with regular temperature inversions and prevailing weak local winds (Otorepec and Gale, 2004), which favors pollutant buildup. The main sources of air pollution include traffic (in particular, diesel vehicles), poor oil burning in some residential areas, burning of high sulfur content coal in small domestic furnaces, and industrial sources (e.g., titanium production plant ( $1 \%$ of the world production), $\mathrm{H}_{2} \mathrm{SO}_{4}$ production, iron works, enamel factory and ceramic industry) (Otorepec and Gale, 2004). In the southern latitude band $\left(38-43^{\circ} \mathrm{N}\right)$, both models overpredict at the urban site Avenida Gasteiz in Spain, and at the urban background site Beato in Portugal, where the observed $\mathrm{SO}_{2}$ concentrations are typically low to moderate (mostly $<4$ and $11 \mu \mathrm{g} \mathrm{m}^{-3}$, respectively). As shown in Figs. 9, 13, and 15 in the Part 1 paper, WRF simulates $10 \mathrm{~m}$ wind speeds well but largely underpredicts peak $2 \mathrm{~m}$ temperatures and overpredicts precipitation on 6-9 and 15-21 July at Avenida Gasteiz. In addition to inaccurate emissions of $\mathrm{SO}_{2}$, the underpredictions in peak $2 \mathrm{~m}$ temperatures may partly explain the peak $\mathrm{SO}_{2}$ concentrations being higher than the observations at this site with both models 

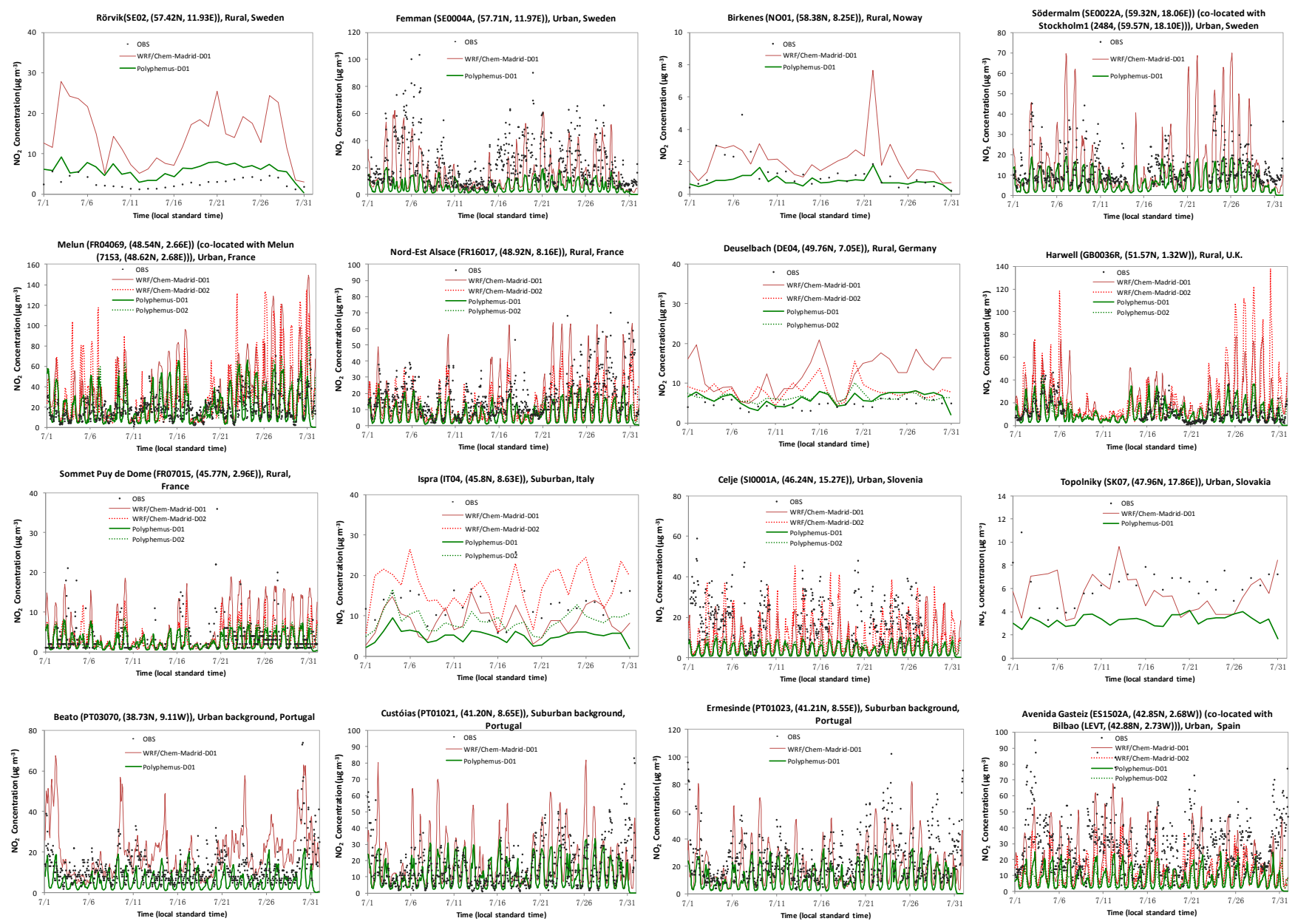

Fig. 4. Simulated and observed hourly or daily concentrations of $\mathrm{NO}_{2}$ in July 2001 at selected sites over D01 and D02 in four latitude bands: $57-60^{\circ} \mathrm{N}, 48-52^{\circ} \mathrm{N}, 45-48^{\circ} \mathrm{N}$, and $38-43^{\circ} \mathrm{N}$ (rows $1,2,3$, and 4 , respectively).

due to insufficient conversion of $\mathrm{SO}_{2}$ to sulfate through gasphase oxidation. At the suburban background site Custóias in Portugal, both models fail to reproduce the extremely high observed concentrations (mostly $>10 \mu \mathrm{g} \mathrm{m}^{-3}$ and can reach as high as $210 \mu \mathrm{g} \mathrm{m}^{-3}$ ). Custóias is located in the Greater Porto area, the second-largest city in northwestern Portugal where the pollutant emissions from its urban and industrial areas are among the highest in Portugal with the major pollution sources from road transport and other combustion processes (Ribeiro et al., 2012). The Porto area features a Mediterranean climate, with warm, dry summers and mild, rainy winters, which favors pollution buildup. At the suburban background site Ermesinde, located $\sim 9 \mathrm{~km}$ northeast of Porto in Portugal, the observed $\mathrm{SO}_{2}$ concentrations are available during 1-14 July and are much lower than those at Custóias. Both models give higher $\mathrm{SO}_{2}$ concentrations in the second half of the month, although no observations are available for comparison.

Figure 4 shows the simulated and observed concentrations of hourly $\mathrm{NO}_{2}$ at the 16 selected sites. In the north- ern latitude band $\left(57-60^{\circ} \mathrm{N}\right)$, at the 2 urban sites in Sweden (Femman and Södermalm), the observed $\mathrm{NO}_{2}$ concentrations are very high, with monthly mean values of 21.4 and $12.7 \mu \mathrm{g} \mathrm{m}^{-3}$ and peak values of 103 and $45 \mu \mathrm{g} \mathrm{m}^{-3}$, respectively. The high $\mathrm{NO}_{2}$ concentrations at Femman and Gothenburg are due partly to high $\mathrm{NO}_{2}$ emissions from local vehicles and ships and partly to meteorological factors that lead to reduced local dispersion due to special topography (Haeger-Eugensson et al., 2010). Many streets at and near Södermalm in central Stockholm have very high levels of air pollutants due to high emissions of $\mathrm{CO}, \mathrm{NO}_{\mathrm{x}}$, VOCs, and $\mathrm{PM}_{10}$ from road traffic (SLB-analys, 2006); additional $\mathrm{NO}_{2}$ results from local photochemical reactions (Johansson and Forsberg, 2005), as well as unfavorable weather conditions for dispersion. While WRF/Polyphemus significantly underpredicts observed high $\mathrm{NO}_{2}$ concentrations at both sites, WRF/Chem-MADRID shows much better agreement, although it underpredicts $\mathrm{NO}_{2}$ concentrations that are greater than $60 \mu \mathrm{g} \mathrm{m}^{-3}$ during 5-6 and 20 July at Femman and overpredicts peak $\mathrm{NO}_{2}$ concentrations on some days 

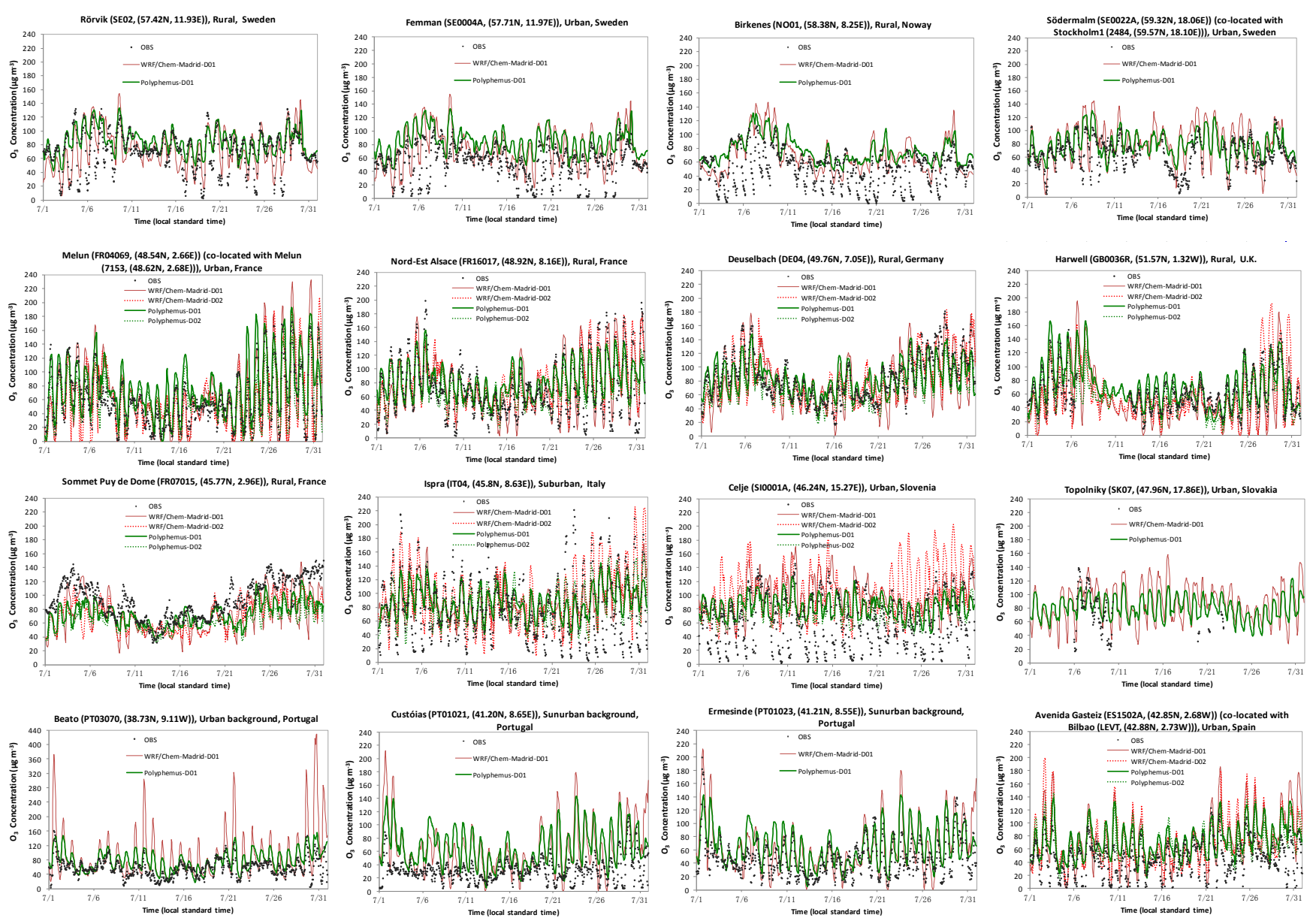

Fig. 5. Simulated and observed concentrations of hourly $\mathrm{O}_{3}$ in July 2001 at selected sites over D01 and D02 in four latitude bands: 57-60 ${ }^{\circ} \mathrm{N}$, $48-52^{\circ} \mathrm{N}, 45-48^{\circ} \mathrm{N}$, and $38-43^{\circ} \mathrm{N}$ (rows $1,2,3$, and 4 , respectively).

(e.g., 7-8, 21-22, 25-26 July). As discussed above, the discrepancies between simulated and observed $\mathrm{NO}_{2}$ concentrations by both models at Södermalm and Femman are most likely caused by underestimation of emissions in the EMEP inventories, rather than biases in the meteorological predictions. At the 2 rural sites Rörvik, Sweden, and Birkenes, Norway, the observed $\mathrm{NO}_{2}$ concentrations are much lower, with monthly mean values of 2.8 and $1.3 \mu \mathrm{g} \mathrm{m}^{-3}$ and peak values of 5.6 and $4.9 \mu \mathrm{g} \mathrm{m}^{-3}$, respectively. Both models overpredict at Rörvik, with much larger overpredictions by WRF/ChemMADRID. At Birkenes, WRF/Polyphemus simulates $\mathrm{NO}_{2}$ well on most days with underpredictions during 5-7 July. While WRF/Chem-MADRID better simulates the observed $\mathrm{NO}_{2}$ levels during 5-6 July, it still underpredicts those on 7 July, and overpredicts significantly those during 19-24 July. In the central latitude band $\left(48-52^{\circ} \mathrm{N}\right)$, the observed $\mathrm{NO}_{2}$ concentrations are typically $>10 \mu \mathrm{g} \mathrm{m}^{-3}$ and can be over $70 \mu \mathrm{g} \mathrm{m}^{-3}$ at the urban site Melun and the rural site Nord-Est Alsace in France. However, those are typically between 3 and $40 \mu \mathrm{g} \mathrm{m}^{-3}$ at Harwell, UK, and between 3 and $7 \mu \mathrm{g} \mathrm{m}^{-3}$ at Deuselbach, Germany. The major $\mathrm{NO}_{2}$ sources in Paris and at Harwell in southern UK are traffic emissions (Aphesis, 2002). While WRF/Polyphemus simulates $\mathrm{NO}_{2}$ concentrations well at Melun and Harwell, WRF/ChemMADRID significantly overpredicts them. Despite large underpredictions in $10 \mathrm{~m}$ wind speeds at Melun, the good performance in $\mathrm{NO}_{2}$ predictions by WRF/Polyphemus but large overpredictions by WRF/Chem-MADRID indicate that biases in meteorological predictions are not a major factor explaining the different performance by the two models. Other factors such as differences in dry and wet deposition treatments and vertical distributions of emissions may explain most differences in the predictions by the two models. At Deuselbach, WRF/Polyphemus underpredicts on most days, and WRF/Chem-MADRID captures the magnitudes better on some days, despite underpredictions on some days. At Nord-Est Alsace, the $\mathrm{NO}_{2}$ concentrations are underpredicted by WRF/Polyphemus and are generally well reproduced by WRF/Chem-MADRID. Nord-Est Alsace is located in Alsace, which is one of most industrialized regions in France, known for its hop harvesting and brewing, automobile industry, and phosphate mining. It is also one of the main 
routes between France and Germany. This area thus has high $\mathrm{NO}_{2}$ emissions from road traffic and various industrial sources. In the central south latitude band $\left(45-48^{\circ} \mathrm{N}\right)$, the observed $\mathrm{NO}_{2}$ concentrations are high at the urban site Celje, Slovenia $\left(1-59 \mu \mathrm{g} \mathrm{m}^{-3}\right.$, mostly $>3 \mu \mathrm{g} \mathrm{m}^{-3}$, a monthly average of $19.5 \mu \mathrm{g} \mathrm{m}^{-3}$ ) due to high $\mathrm{NO}_{2}$ emissions from industry, diesel vehicles, and residential combustions and the weather conditions that favor pollutant buildup. They are relatively low at the other 3 sites due to lower sources of $\mathrm{NO}_{2}$, with $1-36,6-26$, and $3-11 \mu \mathrm{g} \mathrm{m}^{-3}$ and monthlymean values of $3.7,13.0$, and $6.3 \mu \mathrm{g} \mathrm{m}^{-3}$, respectively, at Sommet Puy-de-Dôme, France; Ispra, Italy; and Topolniky, Slovakia. WRF/Chem-MADRID reproduces the observed $\mathrm{NO}_{2}$ concentrations at Celje and Sommet Puy-de-Dôme on most days and at Ispra and Topolniky on some days, despite some underpredictions on some days at those sites. WRF/Polyphemus significantly underpredicts observations at all these sites. In the southern latitude band $\left(38-43^{\circ} \mathrm{N}\right)$, the observed $\mathrm{NO}_{2}$ concentrations are above $10 \mu \mathrm{g} \mathrm{m}^{-3}$ during most hours at all sites; they are in the range of 3-102, $2-95,1-83$, and $2-74 \mu \mathrm{g} \mathrm{m}^{-3}$ with monthly-mean values of 24.1, 28.9, 16.3, and $11.8 \mu \mathrm{g} \mathrm{m}^{-3}$, respectively, at Ermesinde, Portugal; Avenida Gasteiz, Spain; Custóias, Portugal; and Beato, Portugal. Many manufacturing companies have operations in the Gasteiz area (including automobiles, tires, games, cookies, pasta, and flour), producing large $\mathrm{NO}_{2}$ emissions. Its mild, humid temperate climate with warm summers also favors the photochemistry, which further enhances the local $\mathrm{NO}_{2}$ levels at Avenida Gasteiz. The 3 urban or suburban background sites are located in the largest and second largest cities (i.e., Lisbon and Porto) in Portugal and their vicinity, where vehicle exhausts from road traffic provide a significant source of $\mathrm{CO}, \mathrm{NO}_{\mathrm{x}}$, and VOCs (Barros et al., 2003; Ribeiro et al., 2012). The Mediterranean climate in these areas, with warm or hot and dry summers, favors photochemistry, which further enhances the $\mathrm{NO}_{2}$ levels via greater $\mathrm{O}_{3}$ concentrations available for NO titration. At all these sites, WRF/Chem-MADRID gives better agreement with observations than WRF/Polyphemus, despite discrepancies on some days. While the underpredictions in peak $2 \mathrm{~m}$ temperatures may contribute to the underpredictions in peak $\mathrm{NO}_{2}$ concentrations at this site by both models due to less photochemistry as a result of less solar radiation and lower emissions of biogenic volatile organic compounds (BVOCs), inaccurate emissions of $\mathrm{NO}_{2}$ in the EMEP inventory may play a more important role in the biases in the $\mathrm{NO}_{2}$ predictions.

Figures 5 and 6 show simulated and observed concentrations of hourly and maximum $8 \mathrm{~h} \mathrm{O}_{3}$, respectively, at the 16 selected sites. The European Union (EU) air quality standard for maximum $8 \mathrm{~h} \mathrm{O}_{3}$ is $120 \mu \mathrm{g} \mathrm{m}^{-3}$ (with 25 exceedances allowed per year). Some European countries also have a standard for maximum $1 \mathrm{~h} \mathrm{O}$. For example, the maximum $1 \mathrm{~h}$ $\mathrm{O}_{3}$ standard of Italy is $180 \mu \mathrm{g} \mathrm{m}^{-3}$. In the northern latitude band $\left(57-60^{\circ} \mathrm{N}\right)$, the observed hourly $\mathrm{O}_{3}$ concentrations at the 4 sites are similar in terms of magnitudes (up to
$132 \mu \mathrm{g} \mathrm{m}^{-3}$ ) and diurnal variations. The $\mathrm{O}_{3}$ concentrations exhibit a strong diurnal variation with nighttime $\mathrm{O}_{3}$ levels as low as $1-3 \mu \mathrm{g} \mathrm{m}^{-3}$ at these sites, particularly at Birkenes and Femman. The observed daily variation trends and magnitudes (up to $122 \mu \mathrm{g} \mathrm{m}^{-3}$ ) in the maximum $8 \mathrm{~h} \mathrm{O}_{3}$ are also similar at those sites. Note that the observed high maximum $8 \mathrm{~h} \mathrm{O}_{3}$ concentration of $122 \mu \mathrm{g} \mathrm{m}^{-3}$ is above the EU standard for $\mathrm{O}_{3}$. At the 2 urban sites Femman and Södermalm, local vehicles and ships are predominant sources of $\mathrm{CO}$, $\mathrm{NO}_{2}$, and VOCs, leading to high $\mathrm{O}_{3}$ formation. While $\mathrm{NO}_{2}$ concentrations at Rörvik and Birkenes are low, the $\mathrm{O}_{3}$ concentrations are similar to those at the 2 urban sites, indicating other possible causes such as the long-range transport (LRT) $\mathrm{O}_{3}$ and $\mathrm{O}_{3}$ precursors such as $\mathrm{NO}_{\mathrm{x}}$ and VOCs from other European countries such as the UK, Poland, Denmark, and Russia (Øystein et al., 1997). Tang et al. (2009) studied the correlation between synoptic circulation and surface $\mathrm{O}_{3}$ concentrations in southern Sweden and found that $85.5 \%$ of high $\mathrm{O}_{3}$ episodes at Rörvik are associated with three circulation patterns including anticyclonic weather pattern and the directional flows from southeast/east and southwest/south. This indicates a very important role of LRT during high $\mathrm{O}_{3}$ episodes in rural areas in Sweden and Norway. Due to high latitudes, the daytime hours are long $(\sim 18 \mathrm{~h})$ in summer at all these locations, favoring the photochemical $\mathrm{O}_{3}$ formation. The special topography and/or the stable, low wind meteorological conditions at some sites (e.g., Femman and Södermalm in Sweden) also facilitate the pollution buildup. Both models generally capture high $\mathrm{O}_{3}$ concentrations and the day-to-day variations at these sites (except for slight overpredictions on some days). Both models show a good agreement with nighttime $\mathrm{O}_{3}$ at Södermalm. In particular, WRF/Chem-MADRID predicts much higher $\mathrm{NO}_{2}$ concentrations that are in much better agreement with observed nighttime $\mathrm{O}_{3}$ concentrations, illustrating the role of $\mathrm{NO}_{\mathrm{x}}$ titration in determining nighttime $\mathrm{O}_{3}$ levels. Both models, however, fail to reproduce the low $\mathrm{O}_{3}$ concentrations at night at Rörvik, Femman, and Birkenes for different reasons. At Femman, the underpredictions of $\mathrm{NO}_{\mathrm{x}}$ by both models (see Fig. 4) may have led to an insufficient titration of $\mathrm{O}_{3}$ at night. At Rörvik and Birkenes, where observed $\mathrm{NO}_{\mathrm{x}}$ concentrations are low, the very low observed nighttime $\mathrm{O}_{3}$ concentrations may be caused by several other mechanisms. For example, $\mathrm{O}_{3}$ can be destroyed by hydroxyl, hydroperoxyl, or organic radicals $\left(\mathrm{OH}, \mathrm{HO}_{2}\right.$, and $\mathrm{RO}_{2}$ ) (note that $\mathrm{RO}_{2}$ can be produced from VOCs transported into these areas) in low- $\mathrm{NO}_{\mathrm{x}}$ conditions, dominating nighttime $\mathrm{O}_{3}$ chemistry (Monks, 2005). Both sites are on the coast, where the concentrations of sea salt are high. Chlorine/bromine atoms $(\mathrm{Cl}$ and $\mathrm{Br})$ may be produced from heterogeneous reactions of sea salt with acidic species such as $\mathrm{H}_{2} \mathrm{SO}_{4}$ and $\mathrm{HNO}_{3}$ at night (Monk, 2005; Jacobson, 2012), which can then destroy nighttime $\mathrm{O}_{3}$ efficiently. Neither model includes the heterogeneous reactions of sea salt, and both models may underpredict concentrations of VOCs and associated $\mathrm{RO}_{2}$ radicals 
at Rörvik and Birkenes, leading to insufficient nighttime destruction of $\mathrm{O}_{3}$ at both sites. For maximum $8 \mathrm{~h} \mathrm{O}_{3}$, both models give better agreement than hourly $\mathrm{O}_{3}$, illustrating the models' capability of capturing daytime high $\mathrm{O}_{3}$.

In the central latitude band $\left(48-52^{\circ} \mathrm{N}\right)$, the observed $\mathrm{O}_{3}$ concentrations at the four sites are much higher than those in the northern latitude band due to higher emissions of $\mathrm{NO}_{\mathrm{x}}$ or VOCs or both at Melun and Harwell, which are located in the two largest metropolitan areas with dense population in Western Europe (i.e., Paris and London), and at Nord-Est Alsace, which is located in an industrialized region, or due likely to the influence of LRT on $\mathrm{O}_{3}$ levels at Deuselbach, where there is no significant local sources and emissions from polluted areas east and southeast of Deuselbach, such as Frankfurt (Andre et al., 1981). The observed hourly $\mathrm{O}_{3}$ concentrations can reach up to $172 \mu \mathrm{g} \mathrm{m}^{-3}$

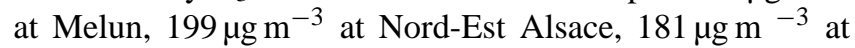
Deuselbach, and $154 \mu \mathrm{g} \mathrm{m}^{-3}$ at Harwell, close to or above the hourly $\mathrm{O}_{3}$ standard of $180 \mu \mathrm{g} \mathrm{m}^{-3}$ in some European countries. The observed maximum $8 \mathrm{~h} \mathrm{O}_{3}$ concentrations can reach up to $159 \mu \mathrm{g} \mathrm{m}^{-3}$ at Melun, $176 \mu \mathrm{g} \mathrm{m}^{-3}$ at Nord-Est Alsace, $170 \mu \mathrm{g} \mathrm{m}^{-3}$ at Deuselbach, and $131 \mu \mathrm{g} \mathrm{m}^{-3}$ at Harwell, all of which are well above the EU maximum $8 \mathrm{O}_{3}$ standard of $120 \mu \mathrm{g} \mathrm{m}^{-3}$. The first and last weeks of July 2001 are high $\mathrm{O}_{3}$ episodes in these areas. At these sites, WRF/ChemMADRID reproduces both daytime and nighttime $\mathrm{O}_{3}$ levels very well, despite some overpredictions of daytime peak $\mathrm{O}_{3}$ due in part to overpredicted $\mathrm{NO}_{2}$ concentrations and in part to biases in meteorological predictions (e.g., underpredicted $10 \mathrm{~m}$ wind speed at Melun) and despite underpredictions of nighttime low $\mathrm{O}_{3}$ levels due to overpredicted titration of nighttime $\mathrm{O}_{3}$ by $\mathrm{NO}_{x}$ during a few hours at some sites (e.g., 3-5 July at Melun and 26-31 July at Harwell). As shown in Fig. 13 in Part 1, wind speeds are significantly underpredicted at Melun, which may explain in part the overpredictions in the $\mathrm{SO}_{2}$ concentrations at Melun due to underestimated dispersion. WRF/Polyphemus captures well the $\mathrm{O}_{3}$ concentrations and diurnal variations at Melun and Harwell, but tends to underpredict the daytime peak $\mathrm{O}_{3}$ levels and overpredict the nighttime low $\mathrm{O}_{3}$ levels at Nord-Est Alsace and Deuselbach. Both models simulate maximum $8 \mathrm{~h}$ $\mathrm{O}_{3}$ well on most days at Melun: WRF/Chem-MADRID gives better agreement than WRF/Polyphemus at Nord-Est Alsace and Deuselbach, and WRF/Polyphemus gives better agreement at Harwell.

In the central south latitude band $\left(45-48^{\circ} \mathrm{N}\right)$, the observed hourly and maximum $8 \mathrm{~h} \mathrm{O}_{3}$ levels at Ispra are the highest among the four sites, reaching 252 and $197 \mu \mathrm{g} \mathrm{m}^{-3}$, respectively, in late afternoon (15:00-16:00 local standard time), both of which exceeded the EU maximum $8 \mathrm{~h}$ standards and the hourly $\mathrm{O}_{3}$ standards adopted in some European countries. This is because of the transport of $\mathrm{O}_{3}$ and/or $\mathrm{O}_{3}$ precursors from more polluted areas such as Milan to Ispra when mountain breeze develops in the afternoon and when the prevailing wind direction is from the south, where the urban and the industrial areas are located (Perrino and Putaud, 2003). Exceedances of the maximum $8 \mathrm{~h} \mathrm{O}_{3}$ at other sites on some days also occurred on some days at other sites. The model performance varies strongly from site to site. At the rural site Sommet Puy-de-Dôme in France, while both models generally capture the day-to-day variation of hourly $\mathrm{O}_{3}$ (e.g., relatively higher observed $\mathrm{O}_{3}$ levels during 2-7 July and 2231 July ), WRF/Chem-MADRID shows better agreement in terms of amplitudes of daily variations and magnitudes of the peak $\mathrm{O}_{3}$ concentrations. At the suburban site Ispra, Italy, WRF/Chem-MADRID gives better agreement with observed hourly $\mathrm{O}_{3}$ than WRF/Polyphemus, although it still underpredicts peak $\mathrm{O}_{3}$ on some days and overpredicts the minimal $\mathrm{O}_{3}$ on most days. At the urban site Celje, Slovenia, WRF/Chem-MADRID overpredicts daytime $\mathrm{O}_{3}$ levels, and WRF/Polyphemus gives better agreement. But both models fail to reproduce the nighttime $\mathrm{O}_{3}$ levels due mainly to underpredictions in $\mathrm{NO}_{\mathrm{x}}$ concentrations (see Fig. 4 for $\mathrm{NO}_{2}$ predictions). At another urban site, Topolniky, in Slovakia, a comparison of very limited observational data on a few days shows reasonably good agreement by both models, with better agreement on observed peak $\mathrm{O}_{3}$ concentrations on 6-7 July and minimal nighttime $\mathrm{O}_{3}$ concentrations on 8 9 July by WRF/Chem-MADRID. The observed maximum $8 \mathrm{~h} \mathrm{O}_{3}$ levels are well reproduced but largely underpredicted by WRF/Polyphemus at Sommet Puy-de-Dôme and Ispra. At Celje and Topolniky, while WRF/Chem-MADRID better captures higher maximum $8 \mathrm{~h} \mathrm{O}_{3}$ values $\left(>100 \mu \mathrm{g} \mathrm{m}^{-3}\right)$ on some days, WRF/Polyphemus better captures moderate $\mathrm{O}_{3}$ values $\left(80-100 \mu \mathrm{g} \mathrm{m}^{-3}\right)$ on some days, but neither reproduces lower maximum $8 \mathrm{~h} \mathrm{O}_{3}$ values $\left(<80 \mu \mathrm{g} \mathrm{m}^{-3}\right)$ at Celje due mainly to underpredictions of $\mathrm{NO}_{\mathrm{x}}$ (thus insufficient titration of $\mathrm{O}_{3}$ ) at this site.

In the southern latitude band $\left(38-43^{\circ} \mathrm{N}\right)$, observed $\mathrm{O}_{3}$ levels are overpredicted by both models with much closer agreement with observations by WRF/Polyphemus at the urban background site Beato, Portugal, and are significantly overpredicted by both models at Custóias in Portugal. Both models simulate hourly $\mathrm{O}_{3}$ much better at Ermesinde in Portugal and Avenida Gasteiz in Spain in terms of both daily and hourly variations and magnitudes, despite overpredictions on some days by both models with greater overpredictions on more days by WRF/Chem-MADRID. For maximum $8 \mathrm{~h}$ $\mathrm{O}_{3}$, large overpredictions occur on most days at all sites, in particular, by WRF/Chem-MADRID at Beato and Avenida Gasteiz and by both models at Custóias and Ermesinde.

Figure 7 shows simulated and observed hourly concentrations of $\mathrm{PM}_{2.5}$ and $\mathrm{PM}_{10}$ at four sites where hourly data are available. At Kallio, an urban background site in Helsinki, the capital of Finland, the observed $\mathrm{PM}_{2.5}$ and $\mathrm{PM}_{10}$ concentrations are 9.9 and $20.4 \mu \mathrm{g} \mathrm{m}^{-3}$ for monthly average and can be up to 35.5 and $369.2 \mu \mathrm{g} \mathrm{m}^{-3}$, respectively. Anthropogenic emissions of $\mathrm{PM}_{2.5}$ and their gaseous precursors in Finland are low compared to the more polluted regions in Europe (EMEP, 2006a, b). A total of $50-70 \%$ of 

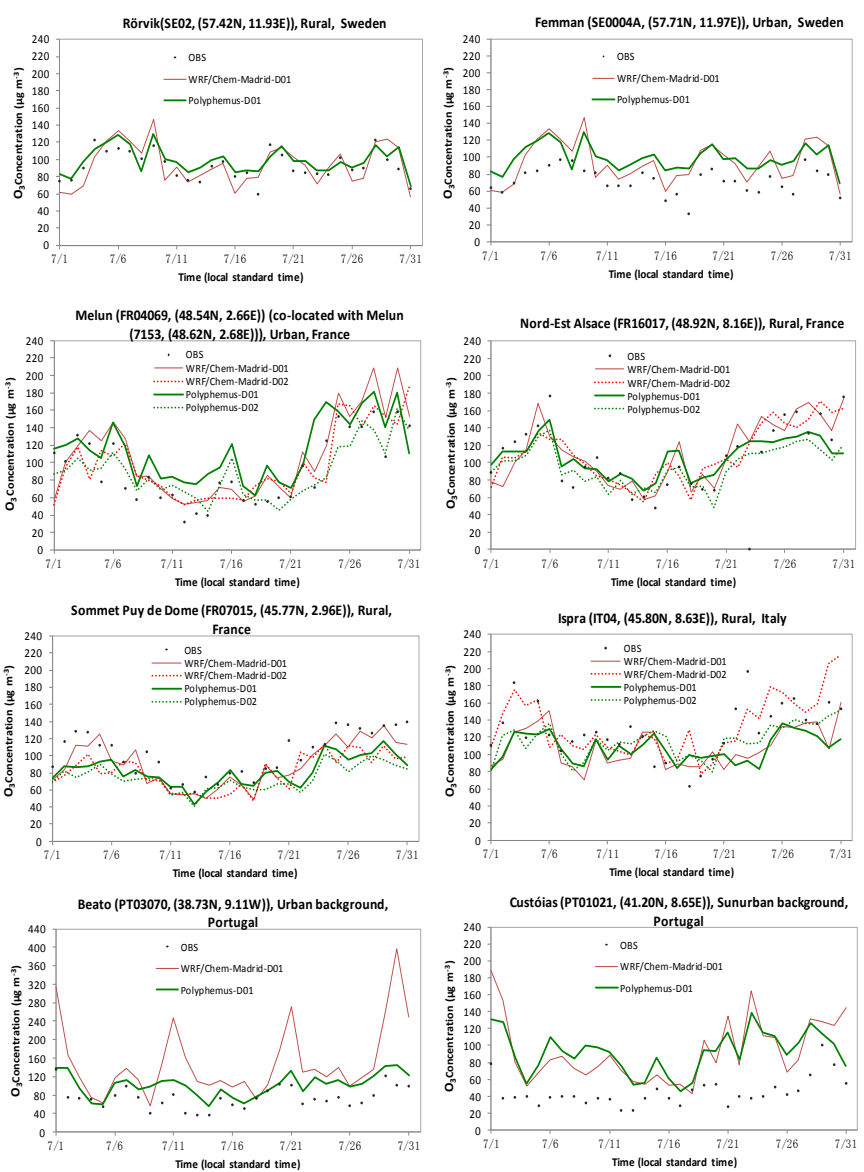
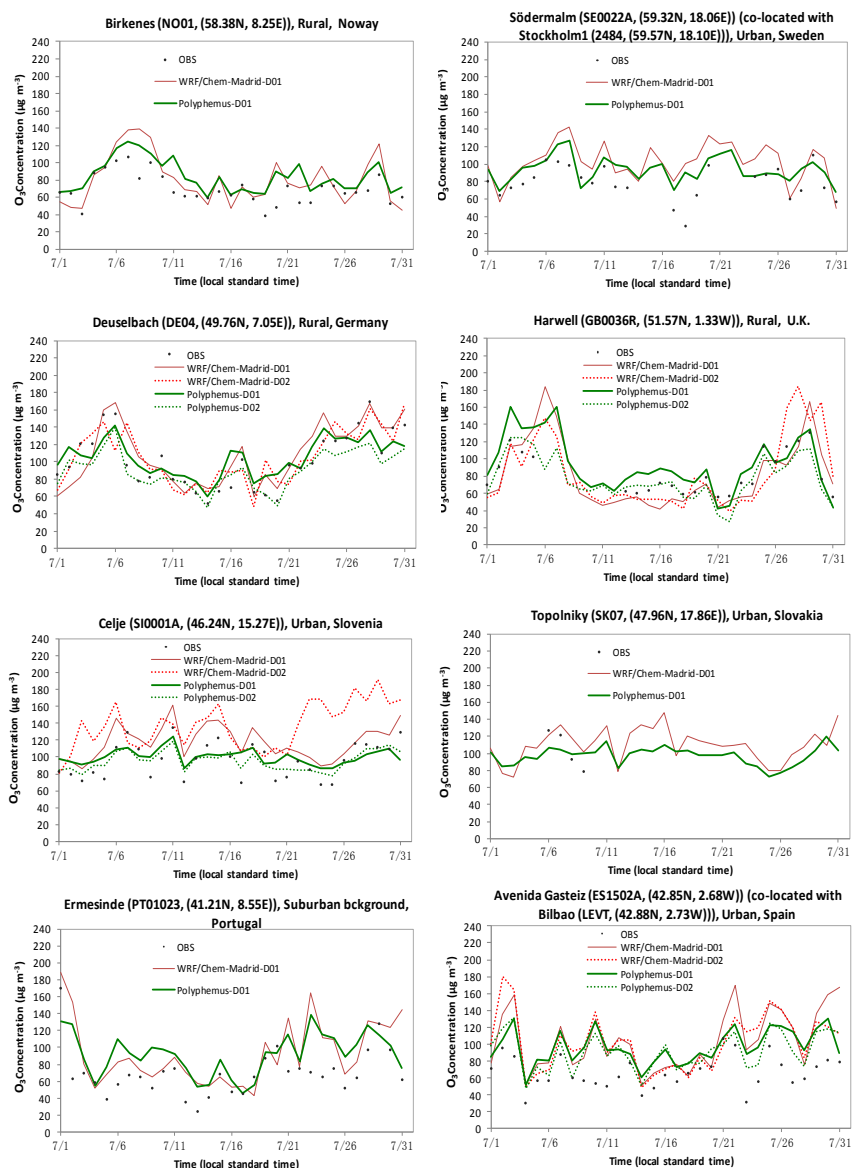

Fig. 6. Simulated and observed concentrations of $\max 8 \mathrm{~h} \mathrm{O}_{3}$ in July 2001 at selected sites over D01 and D02 in four latitude bands: 57-60 $\mathrm{N}$, $48-52^{\circ} \mathrm{N}, 45-48^{\circ} \mathrm{N}$, and $38-43^{\circ} \mathrm{N}$ (rows $1,2,3$, and 4 , respectively).

the $\mathrm{PM}_{2.5}$ mass in the urban areas in Helsinki originates from the LRT of high PM concentrations from several countries such as Estonia, Latvia, Lithuania, Russia, Belarus, Ukraine, and/or Poland, where pollutant emissions from various sources (e.g., energy production, traffic, industry, residential burning, and open biomass burning) are high (Vallius et al., 2003; Karppinen et al., 2004; Sogacheva et al., 2005; Kauhaniemi et al., 2007; van Aardenne et al., 2007). However, the extremely high $\mathrm{PM}_{10}$ concentrations observed on July 25 at this site are most likely due to the resuspension of road dust particles, because road dust is a significant source of mineral particles in urban areas of Finland (Pakkanen et al., 2001; Kupiainen and Tervahattu, 2004; Putaud et al., 2004; Tervahattu et al., 2006; Anttila and Salmi, 2006). WRF/Polyphemus generally reproduces hourly $\mathrm{PM}_{2.5}$ concentrations well, whereas WRF/Chem-MADRID significantly overpredicts it due likely to several factors. First, the concentrations of gaseous precursors of secondary $\mathrm{PM}_{2.5}$ (e.g., $\mathrm{SO}_{4}^{2-}, \mathrm{NH}_{4}^{+}$, and $\mathrm{NO}_{3}^{-}$) such as $\mathrm{SO}_{2}, \mathrm{NH}_{3}$, and $\mathrm{HNO}_{3}$ and primary $\mathrm{PM}$ species are overpredicted due to lower heights of first model layers for some grid cells and thinner thickness of the model layer and the use of lower dry deposition velocities of the gas precursors as described in the Part 1 paper. Second, the dry deposition velocities of $\mathrm{PM}_{2.5}$ species calculated in WRF/Chem-MADRID may also be lower than those of WRF/Polyphemus. Third, the wet scavenging rates calculated in WRF/Chem-MADRID may be lower than those in WRF/Polyphemus. The observed hourly $\mathrm{PM}_{10}$ concentrations are significantly underpredicted by WRF/Polyphemus due to neglect of road dust emissions in the EMEP inventories and much better reproduced by WRF/Chem-MADRID due to inclusion of online soil dust emissions and higher seasalt concentrations even though underpredictions remain on most days. Neither model reproduces several extremely high $\mathrm{PM}_{10}$ episodes (>100 $\left.\mathrm{\mu g} \mathrm{m}^{-3}\right)$ during 7, 12, 25, and 30 July due to missing road dust emissions in the EMEP inventories.

The main sources of $\mathrm{PM}_{10}$ in the UK in 2001 include road transport emissions (in particular, exhaust gases from diesel engines), other sectors such as solvent processes, agriculture, and waste treatment, industrial processes (e.g., the production of metals, cement, lime, coke and chemicals, bulk handling of dusty materials, construction, mining and 


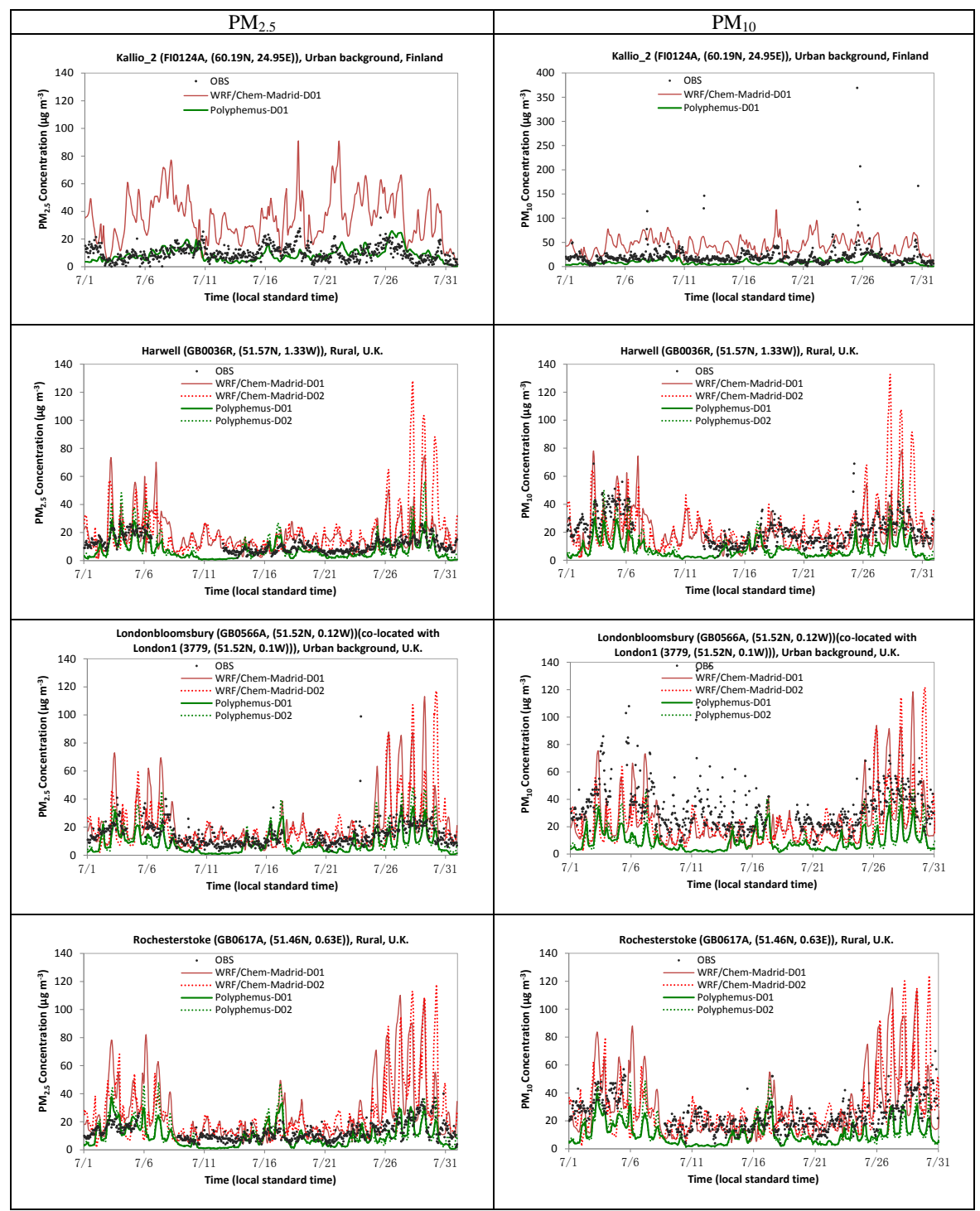

Fig. 7. Simulated and observed hourly concentrations of $\mathrm{PM}_{2.5}$ and $\mathrm{PM}_{10}$ in July 2001 at selected sites over D01 and D02.

quarrying), commercial, domestic and agricultural combustion (e.g., mainly of coal and solid fuels), industrial combustion, and energy industries (i.e., power generation) (MacCarthy et al., 2012). Observed and simulated $\mathrm{PM}_{2.5}$ and $\mathrm{PM}_{10}$ concentrations at three sites are shown in Fig. 7. The urban background site London Bloomsbury, located in central London, is surrounded by a busy two-lane, one-way road system and subject to frequent congestion. It has the highest $\mathrm{PM}_{2.5}$ and $\mathrm{PM}_{10}$ concentrations among the three sites in the UK. The observed $\mathrm{PM}_{2.5}$ and $\mathrm{PM}_{10}$ concentrations at this site are 14.5 and $32.9 \mu \mathrm{g} \mathrm{m}^{-3}$ for monthly average and can be up to 99 and $137 \mu \mathrm{g} \mathrm{m}^{-3}$, respectively. WRF/Polyphemus generally reproduces hourly $\mathrm{PM}_{2.5}$ concentrations in terms of daily variations and magnitudes, whereas WRF/ChemMADRID significantly overpredicts the concentrations in early and late July. Despite underpredictions in the first half of July and overpredictions in late July, WRF/ChemMADRID gives much higher $\mathrm{PM}_{10}$ concentrations and thus better agreement with observations than WRF/Polyphemus due mainly to the inclusion of online road dust emissions. As shown in Fig. 12 in Part 1, WRF largely underpredicts $10 \mathrm{~m}$ wind speed at London, which may contribute in part to the overpredictions in $\mathrm{PM}_{2.5}$ and $\mathrm{PM}_{10}$ concentrations at this site. At the rural site Rochester Stoke, located in the city of Rochester about $48 \mathrm{~km}$ from London in the southeastern corner of England, WRF/Polyphemus generally captures the daily variations and magnitudes of the hourly $\mathrm{PM}_{2.5}$ concentrations, whereas WRF/Chem-MADRID significantly overpredicts them. Despite large underpredictions in early and late July, WRF/Chem-MADRID gives better agreement for 

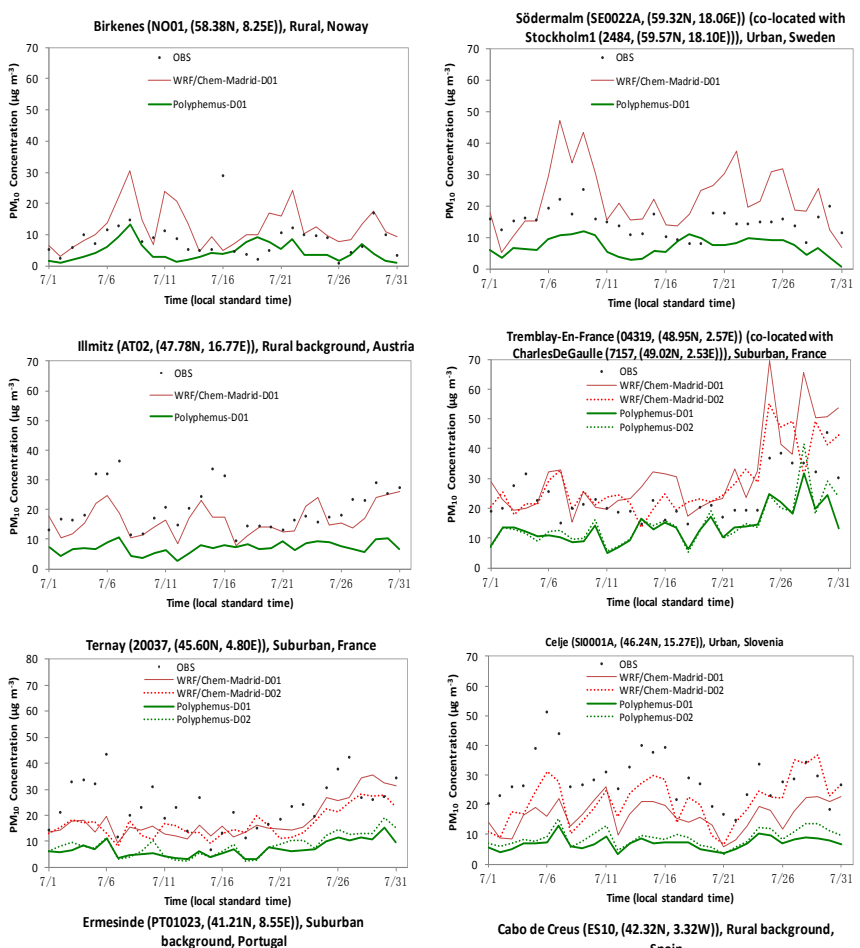

Cabo de Creus (ES10, (42.32N, 3.32W)), Rural background,

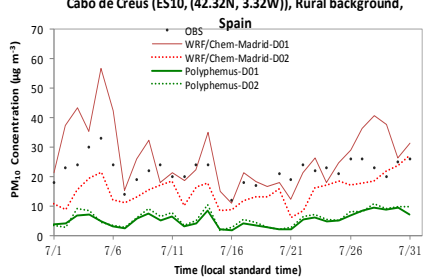

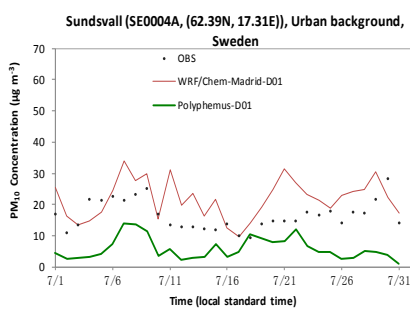

Deuselbach (DE04, (49.76N, 7.05E)), Rural, Germany
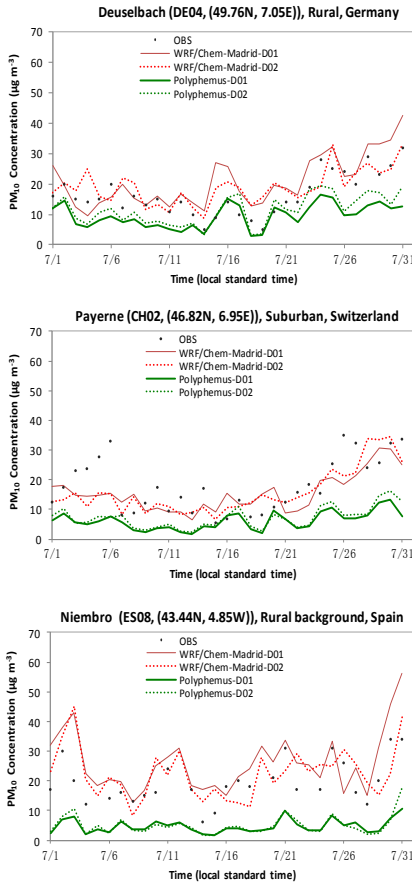
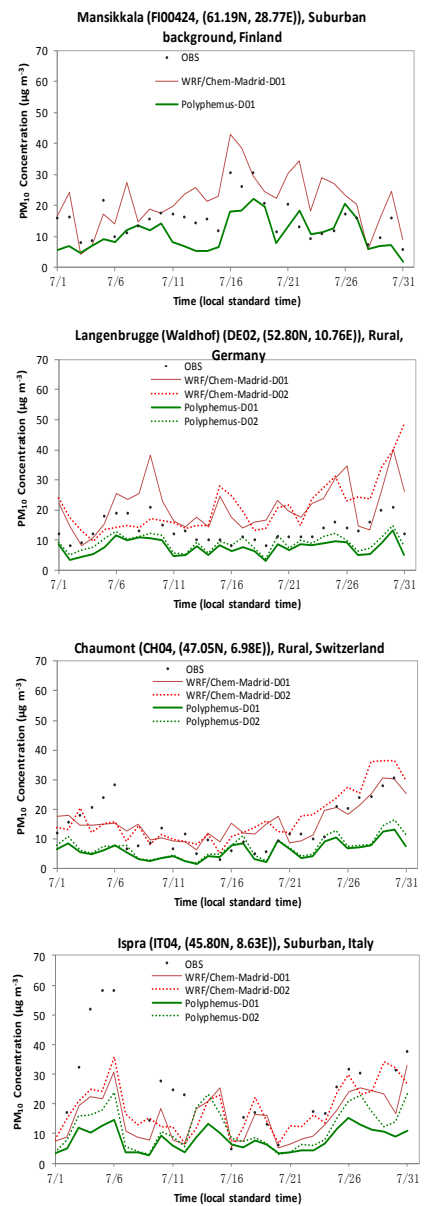

Fig. 8. Simulated and observed concentrations of $24 \mathrm{~h}$ average $\mathrm{PM}_{10}$ at July 2001 selected sites over D01 and D02 in four latitude bands: $57-60^{\circ} \mathrm{N}, 48-52^{\circ} \mathrm{N}, 45-48^{\circ} \mathrm{N}$, and $38-43^{\circ} \mathrm{N}$ (rows $1,2,3$, and 4 , respectively).

hourly $\mathrm{PM}_{10}$ concentrations in terms of both daily variations and magnitudes, compared to WRF/Polyphemus, which significantly underpredicts $\mathrm{PM}_{10}$ concentrations on most days. At the rural site Harwell, UK, WRF/Chem-MADRID significantly overpredicts the concentrations of $\mathrm{PM}_{2.5}$, and WRF/Polyphemus simulates them well. WRF/Polyphemus tends to underpredict hourly $\mathrm{PM}_{10}$ concentrations on most days; on the other hand, WRF/Chem-MADRID gives better agreement on most days except for 26 and 28-30 July.

Figure 8 shows simulated and observed $24 \mathrm{~h}$ average concentrations of $\mathrm{PM}_{10}$ at the 16 sites. In the northern latitude band $\left(57-60^{\circ} \mathrm{N}\right)$, among the 4 sites, the observed $\mathrm{PM}_{10}$ concentrations are the highest at Mansikkala, with a monthly observed mean concentration of $15.2 \mu \mathrm{g} \mathrm{m}^{-3}$ and the peak daily concentration of $30.6 \mu \mathrm{g} \mathrm{m}^{-3}$. Mansikkala is a suburban background located in Imatra, an industrial and coastal town in southern Finland, where the $\mathrm{PM}_{10}$ concentrations are affected by local sources, LRT of $\mathrm{PM}_{10}$ from Eastern European countries, and sea-salt emissions. The observed $\mathrm{PM}_{10}$ concentrations are also high at Södermalm, an urban site, located in central Stockholm on the south- central east coast of Sweden and Sundsvall, an urban background site on the east coast and middle portion of Sweden, with monthly observed mean concentrations of 14.8 and $16.5 \mu \mathrm{g} \mathrm{m}^{-3}$ and the peak daily concentrations of 25.2 and $28.2 \mathrm{\mu g} \mathrm{m}^{-3}$, respectively. Stockholm air is dirtier than that of Los Angeles, according to the most recent report from the World Health Organization (WHO) (http://www.who.int/ phe/health_topics/outdoorair/databases/en/index.html). Road traffic is the most important source of particles in Stockholm's inner city; in particular, vehicle exhaust emissions produce ultrafine particles as a result of imperfect combustion of diesel and petrol (Johansson et al., 2004, 2007; Norman and Johansson, 2006). The observed $\mathrm{PM}_{10}$ concentrations are relatively low at Birkenes, a rural, coastal site $\sim 30 \mathrm{~km}$ from Kristiansand in southern Norway with a monthly observed mean concentration of $8.4 \mu \mathrm{g} \mathrm{m}^{-3}$ and the peak daily concentration of $28.9 \mu \mathrm{g} \mathrm{m}^{-3}$. WRF/Polyphemus underpredicts $\mathrm{PM}_{10}$ concentrations at all sites, whereas WRF/Chem-MADRID overpredicts them, in particular, at Södermalm. Such differences may be attributed to a different emission module of sea salt with higher sea-salt emissions 


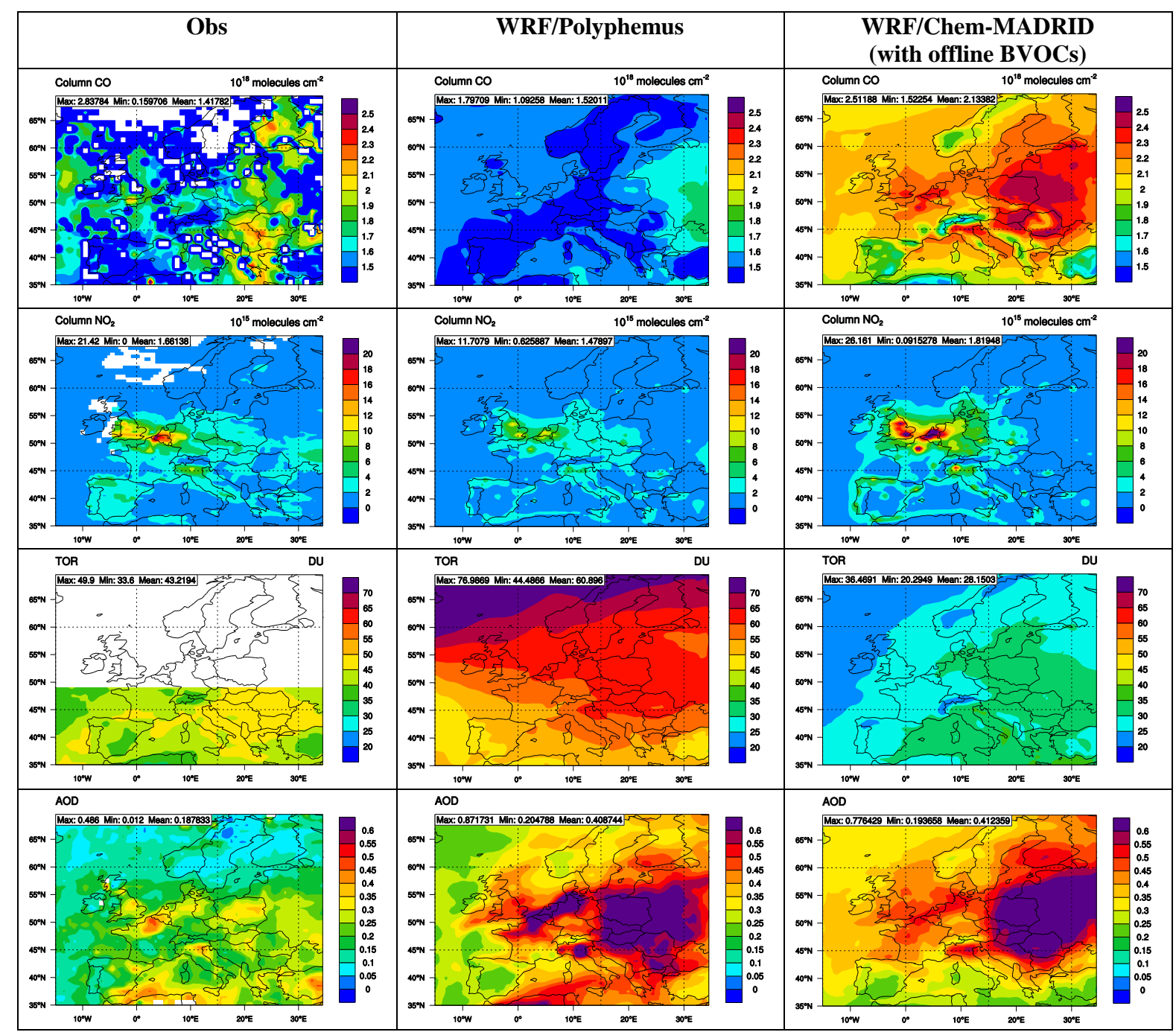

Fig. 9. Simulated and observed monthly mean column mass abundance of $\mathrm{CO}$ and $\mathrm{NO}_{2}$, tropospheric ozone residual (TOR), and aerosol optical depth (AOD) over D01.

from WRF/Chem-MADRID and the inclusion of emissions of soil dust.

In the central latitude band $\left(48-52^{\circ} \mathrm{N}\right)$, the observed $\mathrm{PM}_{10}$ concentrations are higher at Illmitz, Tremblay-enFrance, and Deuselbach than at sites in Nordic Europe, with monthly observed mean concentrations of 20.3, 23.9, and $16.4 \mu \mathrm{g} \mathrm{m}^{-3}$ and the peak daily concentrations of $36.3,45.5$ and $32.0 \mu \mathrm{g} \mathrm{m}^{-3}$, respectively. Illmitz is a rural background site located in the Neusiedler See-Seewinkel National Park on the eastern shore of Lake Neusiedl in eastern Austria. The area has wide open plains and salt marsh flora, with many small salt lakes around. The observed higher $\mathrm{PM}_{10}$ concentrations indicate the influence of LRT of polluted air mass with high $\mathrm{PM}_{2.5}$ concentrations. Based on the wind direction analysis of Barmpadimos et al. (2012), the high PM concentrations are more associated with the east wind direction as compared to the west wind direction, indicating that the sources of high $\mathrm{PM}_{10}$ concentrations most likely originated from Eastern Europe rather than Western Europe because of their higher levels of air pollution. Tremblayen-France is a suburban site in the northeastern suburbs of Paris ( $\sim 19.5 \mathrm{~km}$ from Paris). The high PM concentrations at this site may be caused by local road vehicles. Deuselbach is a rural site located $\sim 150 \mathrm{~km}$ southwest of Cologne in southwestern Germany. The high PM concentrations at this site may be caused by LRT of $\mathrm{PM}_{10}$ concentrations from Cologne. The observed PM concentrations are relatively low at Langenbrugge, with a monthly observed mean concentration of $13.2 \mu \mathrm{g} \mathrm{m}^{-3}$ and the peak daily concentration of $21.0 \mu \mathrm{g} \mathrm{m}^{-3}$. WRF/Polyphemus significantly underpredicts observed $\mathrm{PM}_{10}$ concentrations on most days at all sites. WRF/Chem-MADRID captures them on most days except for underpredictions of high $\mathrm{PM}_{10}$ concentrations $\left(>25 \mu \mathrm{g} \mathrm{m}^{-3}\right)$ on a few days at Illmitz and overpredictions 
of high $\mathrm{PM}_{10}$ concentrations $\left(>30 \mu \mathrm{g} \mathrm{m}^{-3}\right)$ on a few days at Tremblay-En-France. It overpredicts observed $\mathrm{PM}_{10}$ concentrations on most days at Deuselbach and Langenbrugge. As shown in Fig. 12 in Part 1, WRF underpredicts in $10 \mathrm{~m}$ wind speeds at Tremblay-en-France, which may contribute in part the overpredictions in $\mathrm{PM}_{10}$ concentration at this site.

In the central south latitude band $\left(45-48^{\circ} \mathrm{N}\right)$, the observed $\mathrm{PM}_{10}$ concentrations are also high due to high precursor levels and the favorable weather conditions for PM formation and transport. The monthly observed mean concentrations are $23.9,28.7,17.9$, and $13.9 \mu \mathrm{g} \mathrm{m}^{-3}$ and the peak daily concentrations are $43.5,51.1,34.9$, and $30.6 \mu \mathrm{g} \mathrm{m}^{-3}$ at Ternay, Celje, Payerne, and Chaumont, respectively. Ternay is a suburban site located $\sim 18 \mathrm{~km}$ south of Lyon, a large city in southeastern France. Traffic emissions are a major contributor to the concentrations of $\mathrm{PM}_{2.5}$ in this region. Major sources of $\mathrm{PM}_{10}$ include agriculture and forestry, the manufacturing industry (e.g., the Feyzin refinery), the residential/tertiary sector and road transport (http://www. eea.europa.eu/soer/countries/fr). The high level of $\mathrm{PM}_{10}$ at Celje, an urban site, in Slovenia has been a great concern (Otorepec and Gale, 2004). The main sources of $\mathrm{PM}_{10}$ pollution are industry and traffic, including both transit and diesel buses. Payerne is a suburban mountain site located in the Swiss Plateau and surrounded by the Alps on the east and the Jura Mountains on the west in western Switzerland. A total of $59.8 \%$ of its land is used for agricultural purposes. Chaumont is a rural site on the mountain Chaumont in the city of Neuchâtel in western Switzerland. Renowned for its watch industry, Neuchâtel is the heart of micro-technology and high-tech industry. The major $\mathrm{PM}_{10}$ sources in Switzerland include agriculture/forestry, industry, transport, and households (http://www.eea.europa.eu/soer/ countries/ch). While WRF/Polyphemus significantly underpredicts observed $\mathrm{PM}_{10}$ concentrations on nearly all days at all sites, WRF/Chem-MADRID gives better agreement at all sites, in particular, Chaumont.

In the southern latitude band $\left(38-43^{\circ} \mathrm{N}\right)$, the observed $\mathrm{PM}_{10}$ concentrations remain high at all sites, with monthly observed mean concentrations of $34.8,22.1,19.4$, and $26.4 \mu \mathrm{g} \mathrm{m}^{-3}$ and the peak daily concentrations of 78.3, 33.0, 34.0, and 58.2 $\mathrm{\mu g} \mathrm{m}^{-3}$ at Ermesinde, Cabo de Creus, Niembro, and Ispra, respectively. Ermesinde is a suburban background site in the Porto area, where air pollutant emissions are among the largest in Portugal. In addition to domestic sources such as vehicle exhausts from road traffic, suspended road dust, and industry combustions, average daily $\mathrm{PM}_{10}$ concentrations in Portugal can be caused partly by LRT of particles from natural events, particularly from the Sahara desert or forest fires (http://www.eea. europa.eu/soer/countries/pt/). Cabo de Creus is a rural background site in the Cap de Creus peninsula on the easternmost point of mainland Catalonia in Spain, $\sim 25 \mathrm{~km}$ south of the French border. The peninsula is a natural park and very rocky dry region, with almost no trees. The Girona area acts as an industrial, commercial and service hub for a significant part of the province, producing high emissions of air pollutants including $\mathrm{PM}_{10}$. Niembro is a rural background, beach site in the province of Asturias in northern Spain. The major sources of air pollutants in Spain include energy processing (including transport), agriculture, industrial processes, waste treatment and disposal, and solvent use (http://www.eea.europa.eu/soer/countries/es). In addition to the aforementioned emission sources, the resuspended particles from paved roads are an important contributor to $\mathrm{PM}_{10}$ and strongly affect local coarse PM concentrations at both sites (Pay et al., 2011). Ispra is a suburban site in Italy, where transportation (in particular, the roadway transportation) is the main source of $\mathrm{PM}_{10}$ pollution, followed by industry, the residential combustion, and agriculture (http://www.eea. europa.eu/soer/countries/it). While WRF/Polyphemus simulates well the observed $\mathrm{PM}_{2.5}$ concentrations, it significantly underpredicts the observed $\mathrm{PM}_{10}$ concentrations at all sites. On the other hand, WRF/Chem-MADRID tends to overpredict the observed $\mathrm{PM}_{2.5}$ concentrations, but it gives much better agreement for the observed $\mathrm{PM}_{10}$ concentrations probably because of the overprediction of $\mathrm{PM}_{2.5}$ concentrations and because of the inclusion of mineral dust emissions through the use of the online dust emission module and the impact of Saharan dust emissions through boundary conditions, as well as higher sea-salt emissions.

\subsection{Evaluation of column variables}

Figure 9 shows simulated and observed monthly-mean column variables over D01. The corresponding domainwide performance statistics is shown in Table 1. WRF/Polyphemus gives relatively good performance for column $\mathrm{CO}$ and $\mathrm{NO}_{2}$ mass concentrations in terms of domainwide statistics, but it gives a very low correlation coefficient for column $\mathrm{CO}$ and fails to reproduce high observed column CO concentrations in most of the domain. WRF/ChemMADRID significantly overpredicts column $\mathrm{CO}$ and $\mathrm{NO}_{2}$ mass concentrations, but gives better correlation for column $\mathrm{CO}$ and better captures high column $\mathrm{CO}$ and $\mathrm{NO}_{2}$ mass concentrations. The large differences between the column $\mathrm{CO}$ concentrations predicted by the two models are likely caused by differences in the boundary conditions and in the dry position velocity of $\mathrm{CO}$, with higher boundary conditions (by $1.5-39.4 \%$ in layers 6-22) and lower dry position velocity by WRF/Chem-MADRID, leading to higher column CO concentrations. The use of a different number of layers in both models (23 layers in WRF/Chem-MADRID and 22 layers in WRF/Polyphemus) also explains some of the differences in $\mathrm{CO}$. The large differences between the column $\mathrm{NO}_{2}$ concentrations predicted by the two models are likely caused by differences in vertical distributions of $\mathrm{NO}_{\mathrm{x}}$ emissions and the dry deposition velocity of $\mathrm{NO}_{2}$ (with lower values by WRF/Chem-MADRID, leading to higher column $\mathrm{NO}_{2}$ concentrations). WRF/Polyphemus moderately 
overpredicts the tropospheric ozone residual (TOR) with an NMB of $26.8 \%$, whereas WRF/Chem-MADRID moderately underpredicts TOR with an NMB of $-30.6 \%$. Neither captures the observed magnitudes of TOR, with better gradients by WRF/Polyphemus and better correlation by WRF/Chem-MADRID. Despite higher surface $\mathrm{O}_{3}$ concentrations by WRF/Chem-MADRID, WRF/Chem-MADRID gives much higher TOR than WRF/Polyphemus. This indicates that the large differences between TOR concentrations predicted by the two models are caused by different boundary conditions for $\mathrm{O}_{3}$ used in the two model simulations, which are $\sim 47$ and $78 \mu \mathrm{g} \mathrm{m}^{-3}$ for layers $1-19$ and $\sim 26$ and $121 \mu \mathrm{g} \mathrm{m}^{-3}$ for layers above 19 for WRF/ChemMADRID and WRF/Polyphemus, respectively. The values used in WRF/Chem-MADRID are lower by 33.5-82\% than those used in WRF/Polyphemus, leading to a much lower TOR. Aerosol optical depth (AOD) is calculated in a post-processing step at $600 \mathrm{~nm}$, as detailed in Tombette et al. (2008). The aerosol complex refractive index is computed by assuming that black carbon is not internally mixed with other PM species (i.e., having a core/shell structure). The wet diameter is deduced from the dry diameter and the liquid water content obtained from ISORROPIA. In WRF/Chem, AOD is calculated at $550 \mathrm{~nm}$ using the parameterization of Ghan et al. (2001), which performs full Mie calculations to calculate aerosol scattering and absorption coefficients as a function of PM number concentrations, single-particle radius, and single-particle absorption and scattering efficiencies over a set of seven complex refractive indices that represent a range of indices typical of atmospheric aerosols, as described in Fast et al. (2005). Both models significantly overpredict AOD with NMBs of $125 \%$ and $129.6 \%$, respectively, but WRF/Polyphemus shows better correlation for AOD. These AOD overpredictions confirm the hypothesis that underpredictions of PM at individual sites (mostly urban) result mostly from underestimation of local emission inventories (e.g., road dust) or misrepresentation of pollutant vertical distribution rather than regional biases. Similar to column $\mathrm{CO}$ and $\mathrm{NO}_{2}$ predictions, WRF/Chem-MADRID gives higher AOD than WRF/Polyphemus due to aforementioned differences in the model treatments of vertical structures, dry and wet deposition, boundary conditions, and aerosol thermodynamics and dynamics.

\section{Sensitivity simulations}

\subsection{Sensitivity to horizontal grid resolutions}

Figures 1 and 2 show simulated spatial distributions of $\mathrm{SO}_{2}$, $\mathrm{NO}_{2}$, maximum $8 \mathrm{~h} \mathrm{O}_{3}$, and $24 \mathrm{~h}$ average $\mathrm{PM}_{2.5}, \mathrm{PM}_{10}$, and $\mathrm{PM}_{10}$ composition by the two models overlaid with observations over D02 in July. Compared to spatial distributions over D01, the simulations over D02 by both models show greater details in hot spots or areas with lower con- centrations for all species, particularly for $\mathrm{NO}_{2}$, maximum $8 \mathrm{~h} \mathrm{O}_{3}, \mathrm{PM}_{2.5}, \mathrm{NH}_{4}^{+}, \mathrm{NO}_{3}^{-}$, and TOM. Figures 3-6 compare observed and simulated hourly concentrations of $\mathrm{SO}_{2}$, $\mathrm{NO}_{2}$, and $\mathrm{O}_{3}$ and maximum $8 \mathrm{~h} \mathrm{O}$, respectively, from the simulations at horizontal grid resolutions of $0.5^{\circ}$ over D01 and $0.125^{\circ}$ over D02 at 8 sites that fall into the D02 domain. For $\mathrm{SO}_{2}, \mathrm{WRF} /$ Polyphemus predictions at the two grid resolutions are overall similar at Melun, Nord-Est Alsace, and Sommet Puy-de-Dôme, France, where the terrain is either low or uniform but different at mountain/high altitude sites or sites with complex terrain (i.e., Deuselbach, Germany; Harwell, UK; Ispra, Italy; Celje, Slovenia; and Avenida Gasteiz, Spain). WRF/Chem-MADRID also gives similar results at the two grid resolutions at Nord-Est Alsace and Sommet Puy-de-Dôme, France, but shows high sensitivity to grid resolutions at remaining sites. Both models give higher values at $0.125^{\circ}$ over D02, leading to an overall better agreement at most sites except for Deuselbach, Harwell, and Ispra, where the overpredictions are greater. For $\mathrm{NO}_{2}$, WRF/Polyphemus predictions at the two grid resolutions are quite similar at all sites except for Ispra, where the use of a finer grid resolution brings predictions into a better agreement with observations. WRF/Chem-MADRID shows a high sensitivity to grid resolutions at all sites, with better agreement at Nord-Est Alsace and Celje, but worse agreement at Melun, Sommet Puy-de-Dôme, Deuselbach, Harwell, Ispra, and Avenida Gasteiz. For hourly $\mathrm{O}_{3}$, WRF/Polyphemus at both grid resolutions gives similar predictions but with lower nighttime $\mathrm{O}_{3}$ values at a finer grid resolution at all sites, leading to a closer agreement with observations. WRF/ChemMADRID gives higher daytime peak values but lower nighttime values at all sites, leading to an overall better agreement with observations at all sites expect for Celje. For maximum $8 \mathrm{~h} \mathrm{O}_{3}$, WRF/Polyphemus at $0.125^{\circ}$ gives lower values than at $0.5^{\circ}$ on most days at all sites except for Ispra, leading to better agreement with observations. WRF/ChemMADRID shows a higher sensitivity to grid resolutions than WRF/Polyphemus, but the values at $0.125^{\circ}$ could be either higher or lower than those at $0.5^{\circ}$, depending on the sites. This leads to a better agreement with observations at Melun, Nord-Est Alsace, Ispra, and Avenida Gasteiz, but worse agreement at Deuselbach, Sommet Puy-de-Dôme, Harwell, and Celje.

Figures 7-8 compare observed and simulated hourly $\mathrm{PM}_{2.5}$ and $\mathrm{PM}_{10}$ concentrations at 3 sites and $24 \mathrm{~h}$ average concentrations of $\mathrm{PM}_{10}$ at 10 sites that fall into the D02 domain (i.e., Tremblay-en-France and Ternay, France; Deuselbach and Langenbrugge, Germany; Payerne and Chaumont, Switzerland; Ispra, Italy; Celje, Slovenia; Harwell, Rochester Stoke, and London Bloomsbury, UK; and Cabo de Creus and Niembro, Spain). For hourly $\mathrm{PM}_{2.5}$ and $\mathrm{PM}_{10}$, WRF/Polyphemus shows less sensitivity to grid resolutions than WRF/Chem-MADRID at Harwell, Rochester Stoke, and London Bloomsbury, with better agreement with observations. WRF/Chem-MADRID at $0.125^{\circ}$ gives higher 


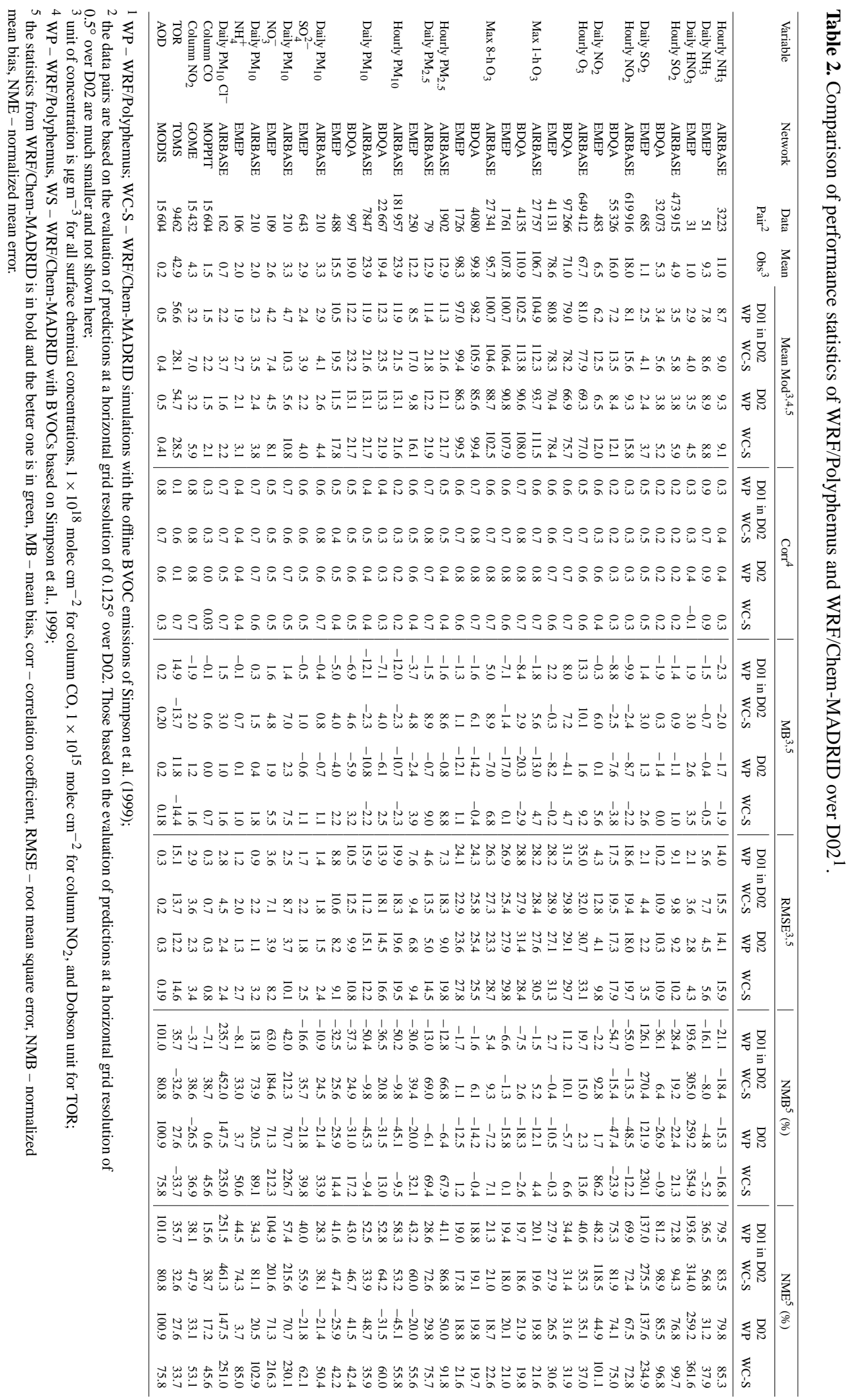




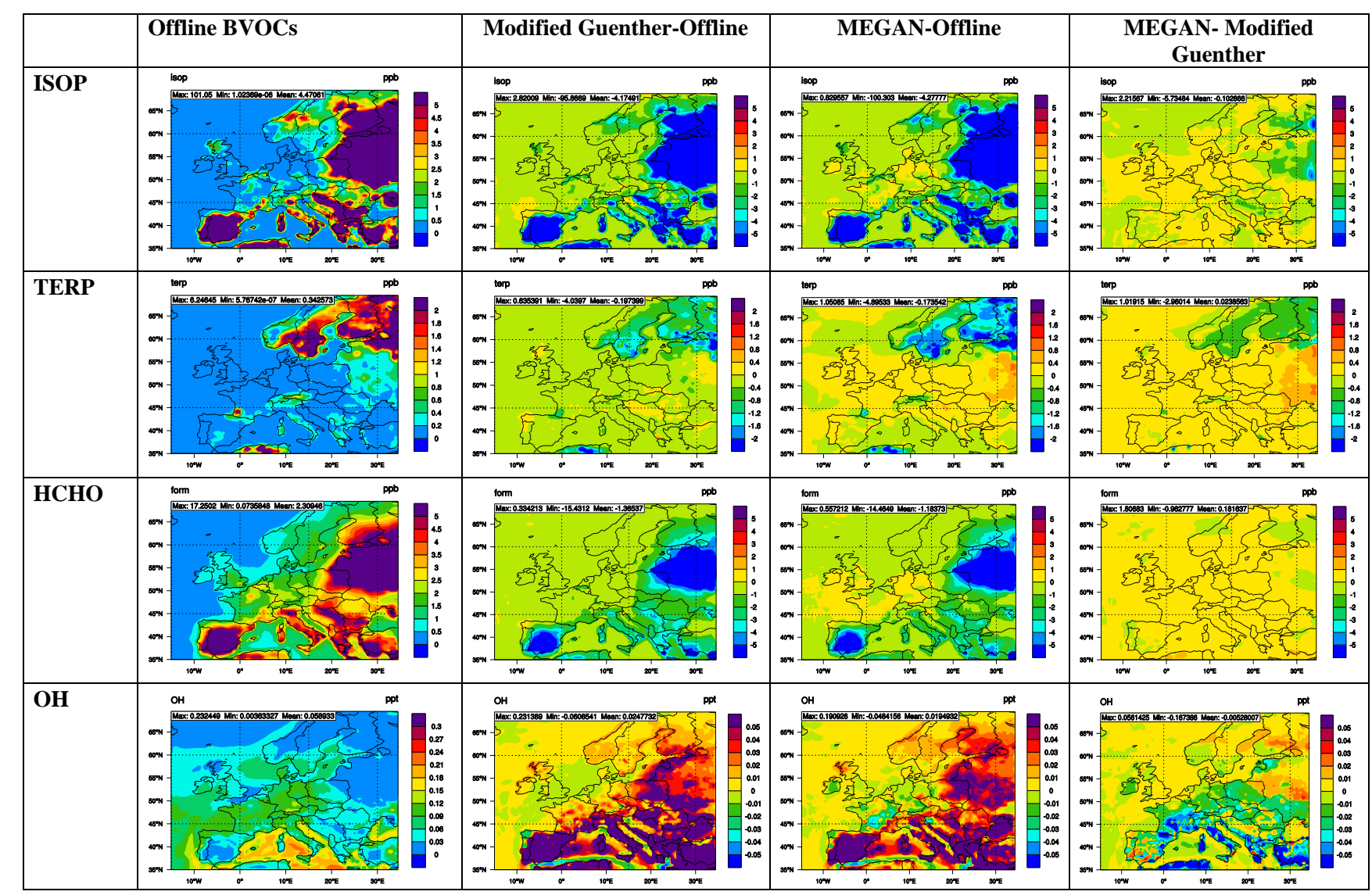

Fig. 10. Simulated concentrations of ISOP, TERP, HCHO, and OH by WRF/Chem-MADRID using offline BVOC emissions of Simpson et al. (1999) (column 1) and the absolute differences in their concentrations between simulations with modified Guenther online module and offline emissions (column 2), between simulations with MEGAN 2 online module and offline emissions (column 3), and between simulations with MEGAN 2 and modified Guenther online modules (column 4) in July 2001 over D01.

values than at $0.5^{\circ}$, leading to greater overpredictions on some days at these sites. For $24 \mathrm{~h} \mathrm{PM}_{10}$ concentrations, $\mathrm{WRF} / \mathrm{Polyphemus}$ at $0.125^{\circ}$ gives slightly higher values at all sites except for Ispra, where the predictions at $0.125^{\circ}$ are much higher, leading to a slightly better agreement with observations. WRF/Chem-MADRID at $0.125^{\circ}$ may give either higher or lower values than at $0.5^{\circ}$, leading to better agreement at Deuselbach, Langenbrugge, Celje, Payerne, Niembro, and Ispra but worse at Tremblay-en-France, Ternay, Chaumont, and Cabo de Creus.

Table 2 shows the corresponding domainwide performance statistics for those species and additional species, such as $\mathrm{NH}_{3}, \mathrm{HNO}_{3}$, and $\mathrm{PM}_{10}$ composition $\mathrm{SO}_{4}^{2-}, \mathrm{NO}_{3}^{-}, \mathrm{NH}_{4}^{+}$, $\mathrm{Na}^{+}$, and $\mathrm{Cl}^{-}$at $0.125^{\circ}$ over D02 and compares them with those from the simulation at $0.5^{\circ}$ but over the same D02 domain to examine the sensitivity of the model predictions to horizontal grid resolutions. For performance statistics at $0.125^{\circ}$ over D02, compared with WRF/Chem-MADRID, WRF/Polyphemus performs better for $\mathrm{NH}_{3}, \mathrm{HNO}_{3}$, daily $\mathrm{SO}_{2}$, and $\mathrm{NO}_{2}$ at the EMEP sites, hourly $\mathrm{O}_{3}$, maximum $1 \mathrm{~h} \mathrm{O}_{3}$ at the EMEP sites, maximum $8 \mathrm{~h} \mathrm{O}_{3}$ at the Air-
Base and BDQA sites, hourly and daily $\mathrm{PM}_{2.5}, \mathrm{PM}_{10}$ composition at all sites, and column $\mathrm{CO}$ and $\mathrm{NO}_{2}$. It performs worse for hourly $\mathrm{SO}_{2}$ and $\mathrm{NO}_{2}$ at the AirBase and BDQA sites, hourly $\mathrm{O}_{3}$, maximum $1 \mathrm{~h} \mathrm{O}_{3}$ at the BDQA and EMEP sites, maximum $8 \mathrm{~h} \mathrm{O}_{3}$ at the EMEP sites, $\mathrm{PM}_{10}$, TOR, and AOD. For both models, the use of a finer grid resolution leads an overall better performance for most variables. For WRF/Polyphemus, the use of a finer grid resolution improves the model performance in terms of NMBs for all variables evaluated except for daily $\mathrm{HNO}_{3}$, hourly $\mathrm{O}_{3}$ against EMEP, maximum $1 \mathrm{~h}$ and $8 \mathrm{~h} \mathrm{O}_{3}$ at all sites, daily $\mathrm{SO}_{4}^{2-}$, daily $\mathrm{NO}_{3}^{-}$, daily $\mathrm{NH}_{4}^{+}$against AirBase, column $\mathrm{NO}_{2}$, and AOD. The relatively large improvement (reducing NMBs by $5 \%$ or more from their values at $0.5^{\circ}$ ) occurs for hourly and daily $\mathrm{NH}_{3}$, hourly $\mathrm{SO}_{2}$ against BDQA, hourly $\mathrm{NO}_{2}$ and hourly $\mathrm{O}_{3}$ against AirBase and BDQA, hourly and daily $\mathrm{PM}_{2.5}$ and $\mathrm{PM}_{10}$, daily $\mathrm{Cl}^{-}$, column $\mathrm{CO}$, and TOR. For WRF/ChemMADRID, the use of a finer grid resolution improves the model performance in terms of NMBs for all variables evaluated except for daily $\mathrm{HNO}_{3}$, hourly $\mathrm{SO}_{2}$ against AirBase, 


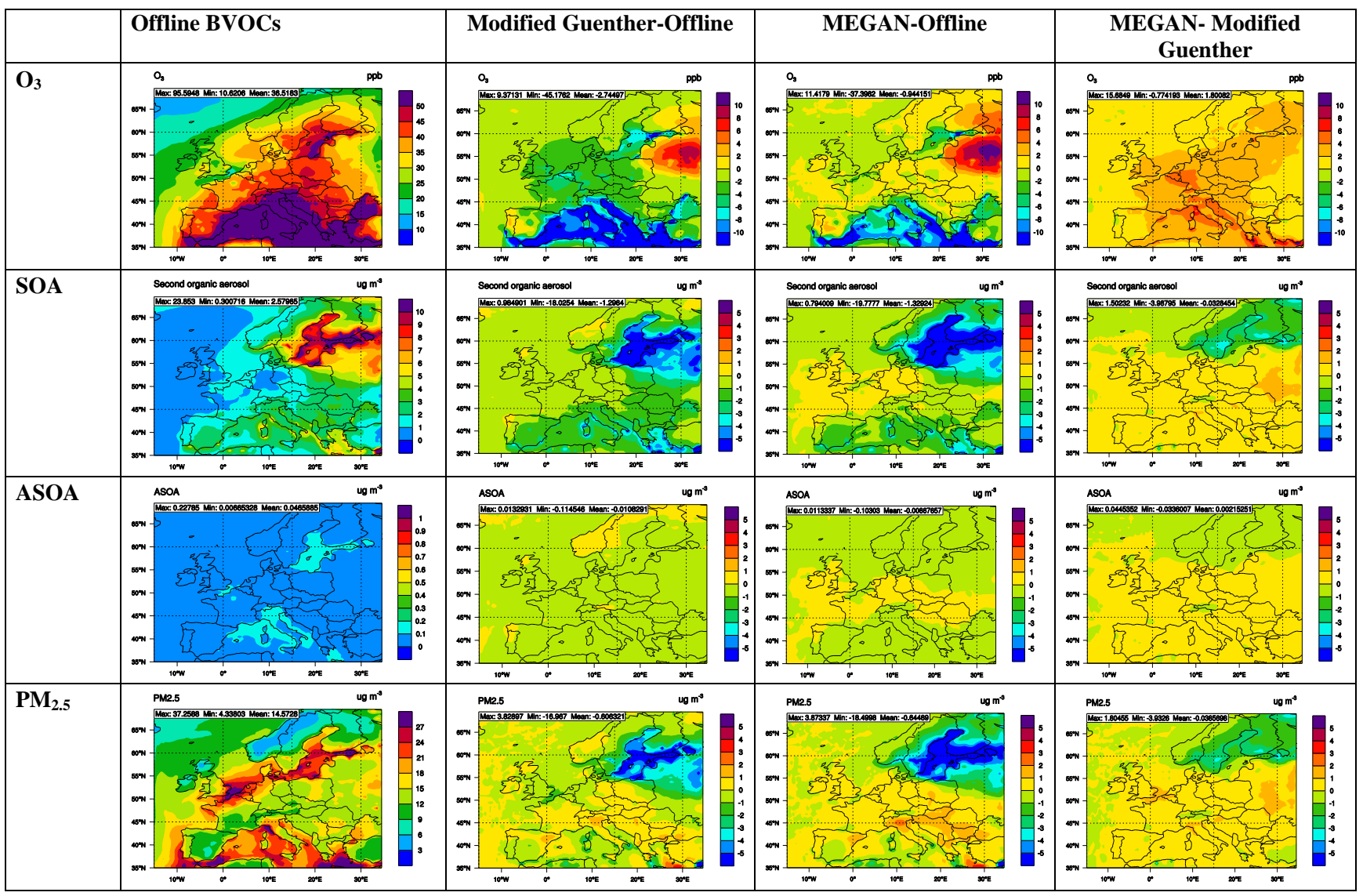

Fig. 11. Simulated concentrations of O3, SOA, ASOA, and $\mathrm{PM}_{2.5}$ species by WRF/Chem-MADRID using offline BVOC emissions of Simpson et al. (1999) (column 1) and the absolute differences in their concentrations between simulations with modified Guenther online module and offline emissions (column 2), between simulations with MEGAN 2 online module and offline emissions (column 3), and between simulations with MEGAN 2 and modified Guenther online modules (column 4) in July 2001 over D01.

hourly $\mathrm{NO}_{2}$ against BDQA, maximum $8 \mathrm{~h} \mathrm{O}$ against EMEP, hourly and daily $\mathrm{PM}_{2.5}$ against AirBase, daily $\mathrm{SO}_{4}^{2-}$, daily $\mathrm{NO}_{3}^{-}$, daily $\mathrm{NH}_{4}^{+}$, and column $\mathrm{CO}, \mathrm{NO}_{2}$, and TOR. The relatively large improvement occurs for hourly $\mathrm{SO}_{2}$ against BDQA, daily $\mathrm{SO}_{2}$ and $\mathrm{NO}_{2}$ against EMEP, maximum $8 \mathrm{~h}$ $\mathrm{O}_{3}$ against BDQA, daily $\mathrm{PM}_{2.5}$ against EMEP, hourly $\mathrm{PM}_{10}$ against BDQA, daily $\mathrm{PM}_{10}$ against BDQA and EMEP, and AOD. As shown, the use of a finer grid resolution does not always improve model performance, nor does not give an expected significant improvement for all species. Similar results were obtained by Bailey et al. (2007), who found better performance for $\mathrm{O}_{3}$ at a finer spatial resolution $(8 \mathrm{~km})$, but better performance for PM at a coarser resolution $(32 \mathrm{~km})$ over the eastern US. Possible reasons can be attributed to inaccuracies or uncertainties in the required inputs (e.g., meteorology, emissions, and land use) at a finer grid resolution due to the limitation of current meteorological models in capturing fine-scale atmospheric processes and the lack of information at a finer grid scale. The grid-averaging of emissions and land use data can influence model predictions. An aver- aging over a coarser grid resolution may sometimes smooth the spatial distribution of the variables concerned (e.g., emissions), leading to a better agreement with observations, although the representation may not be more accurate.

\subsection{Sensitivity to biogenic emissions}

Different BVOC modules produce significantly different BVOC emissions in terms of total emissions and their spatial distributions. For example, the domain-average emission fluxes of isoprene (ISOP) and formaldehyde (HCHO) are 8.1 and $0.05,1.9$ and 0.06 , and 2.5 and $0.07 \mathrm{~mol} \mathrm{~km}^{-2} \mathrm{~h}^{-1}$ for the offline BVOC emissions based on Simpson et al. (1999), online BVOC emissions based on modified Guenther of Guenther et al. $(1993,1999)$ and MEGAN of Guenther et al. (2006) (referred to as WC-S, WC-G, and WC-M, respectively), respectively. Different BVOC emissions result in different chemical predictions from the three simulations, in particular, concentrations of BVOCs, oxidants, radicals, and secondary species that are strongly affected by oxidants and radicals. Figures 10 and 11 show simulated concentrations 
Table 3. Characteristics of sites selected for temporal analysis.

\begin{tabular}{|c|c|c|c|c|c|c|c|}
\hline Country & Site name & $\begin{array}{l}\text { Site ID } \\
\text { (network) }\end{array}$ & Site Type & Latitude & Longitude & $\begin{array}{l}\text { Elevation } \\
(\mathrm{m})\end{array}$ & Characteristics \\
\hline Austria & Illmitz & $\begin{array}{l}\text { AT02 } \\
\text { (EMEP) }\end{array}$ & $\begin{array}{l}\text { Rural Back- } \\
\text { ground }\end{array}$ & $47.78^{\circ} \mathrm{N}$ & $16.77^{\circ} \mathrm{E}$ & 117 & $\begin{array}{l}\text { Located on the eastern shore of Lake Neusiedl in eastern Aus- } \\
\text { tria. It has oceanic climate, featuring warm but not hot summers } \\
\text { and cool but not cold winters. }\end{array}$ \\
\hline Denmark & $\begin{array}{l}\text { Keldsnor/ } \\
9055\end{array}$ & $\begin{array}{l}\text { DK0048A } \\
\text { (AirBase) }\end{array}$ & Rural & $54.75^{\circ} \mathrm{N}$ & $10.74^{\circ} \mathrm{E}$ & 10 & $\begin{array}{l}\text { A coastal site located in southeastern Denmark. The climate is } \\
\text { in the temperate climate zone with cold winters and warm sum- } \\
\text { mers. }\end{array}$ \\
\hline \multirow[t]{2}{*}{ Finland } & Mansikkala & $\begin{array}{l}\text { FI00424 } \\
\text { (AirBase) }\end{array}$ & $\begin{array}{l}\text { Suburban } \\
\text { Background }\end{array}$ & $61.19^{\circ} \mathrm{N}$ & $28.77^{\circ} \mathrm{E}$ & 100 & $\begin{array}{l}\text { Located in the town of Imatra in southern Finland. It has subarc- } \\
\text { tic climate with cool summer, severe winter, and no dry season. }\end{array}$ \\
\hline & Kallio_2 & $\begin{array}{l}\text { FI0124A } \\
\text { (AirBase) }\end{array}$ & $\begin{array}{l}\text { Urban } \\
\text { Background }\end{array}$ & $60.19^{\circ} \mathrm{N}$ & $24.95^{\circ} \mathrm{E}$ & 21 & $\begin{array}{l}\text { Located in Helsinki. This region has a hemiboreal humid conti- } \\
\text { nental climate. Owing to the mitigating influence of the Baltic } \\
\text { Sea and Gulf Stream, temperatures in winter are much higher } \\
\text { than the far northern location, with the average around }-5^{\circ} \mathrm{C} \text {. } \\
\text { The summer average maximum temperature is } 19-21^{\circ} \mathrm{C} \text {. How- } \\
\text { ever, because of the latitude, it has } 19 \mathrm{~h} \text { daytime in summer and } \\
<6 \mathrm{~h} \text { daytime in winters. }\end{array}$ \\
\hline \multirow[t]{5}{*}{ France } & Melun & $\begin{array}{l}\text { FR04069 } \\
\text { (AirBase, } \\
\text { BDQA) }\end{array}$ & Urban & $48.54^{\circ} \mathrm{N}$ & $2.66^{\circ} \mathrm{E}$ & 56 & See Table 5 , Part 1. \\
\hline & $\begin{array}{l}\text { Nord-Est } \\
\text { Alsace }\end{array}$ & $\begin{array}{l}\text { FR16017 } \\
\text { (AirBase, } \\
\text { BDQA) }\end{array}$ & Rural & $48.92^{\circ} \mathrm{N}$ & $8.16^{\circ} \mathrm{E}$ & 114 & $\begin{array}{l}\text { Located in northeastern Alsace, a city on France's eastern bor- } \\
\text { der and on the west bank of the upper Rhine adjacent to Ger- } \\
\text { many and Switzerland. Alsace has a semi-continental climate } \\
\text { with cold and dry winters and hot summers, and little precipita- } \\
\text { tion }\end{array}$ \\
\hline & $\begin{array}{l}\text { Sommet Puy de } \\
\text { Dôme }\end{array}$ & $\begin{array}{l}\text { FR07015 } \\
\text { (AirBase, } \\
\text { BDQA) }\end{array}$ & Rural & $45.77^{\circ} \mathrm{N}$ & $2.96^{\circ} \mathrm{E}$ & 1460 & $\begin{array}{l}\text { Located on the top of the Puy-de-Dôme in south-central France. } \\
\text { Annual average summer high temperature is } 25^{\circ} \mathrm{C} \text { and winter } \\
\text { low temperature is }-1{ }^{\circ} \mathrm{C} \text {, with annual precipitation } 592 \mathrm{~m} \text { and } \\
\text { snow coverage on top of the mountains through May. }\end{array}$ \\
\hline & Ternay & $\begin{array}{l}\text { FR20037 } \\
\text { (AirBase, } \\
\text { BDQA) }\end{array}$ & Suburban & $45.60^{\circ} \mathrm{N}$ & $4.80^{\circ} \mathrm{E}$ & 235 & $\begin{array}{l}\text { Located } \sim 18 \mathrm{~km} \text { south of Lyon. The weather in this region is on } \\
\text { the borderline of oceanic and humid subtropical climate, with } \\
\text { very warm summers }\left(21.3^{\circ} \mathrm{C} \text { on average) and colder winters }\right. \\
\left(3.2^{\circ} \mathrm{C} \text { on average) than much of the south of France due to }\right. \\
\text { its more inland position. Annual average total precipitation is } \\
840 \mathrm{~mm} \text {, with the winter months the driest. }\end{array}$ \\
\hline & $\begin{array}{l}\text { Tremblay-en- } \\
\text { France }\end{array}$ & $\begin{array}{l}\text { FR04319 } \\
\text { (AirBase, } \\
\text { BDQA) }\end{array}$ & Suburban & $48.95^{\circ} \mathrm{N}$ & $2.57^{\circ} \mathrm{E}$ & 65 & In the northeastern suburbs of Paris ( $\sim 19.5 \mathrm{~km}$ from Paris $)$ \\
\hline \multirow[t]{3}{*}{ Germany } & Deuselbach & $\begin{array}{l}\text { DE04 } \\
\text { (EMEP) }\end{array}$ & Rural & $49.76^{\circ} \mathrm{N}$ & $7.05^{\circ} \mathrm{E}$ & 480 & $\begin{array}{l}\text { Located } \sim 150 \mathrm{~km} \text { southwest of Cologne in southwestern Ger- } \\
\text { many. It has an oceanic climate, with annual mean summer and } \\
\text { winter temperatures of } 16.3^{\circ} \mathrm{C} \text { and }-0.6^{\circ} \mathrm{C} \text {, respectively. }\end{array}$ \\
\hline & $\begin{array}{l}\text { Düsseldorf- } \\
\text { Lörick }\end{array}$ & $\begin{array}{l}\text { DENW071 } \\
\text { (AirBase) }\end{array}$ & $\begin{array}{l}\text { Suburban } \\
\text { Background }\end{array}$ & $51.25^{\circ} \mathrm{N}$ & $6.73^{\circ} \mathrm{E}$ & 32 & See Table 5, Part 1. \\
\hline & Langenbrugge & $\begin{array}{l}\text { DE02 } \\
\text { (EMEP) }\end{array}$ & Rural & $52.80^{\circ} \mathrm{N}$ & $10.76^{\circ} \mathrm{E}$ & 74 & $\begin{array}{l}\text { Located on a hill above the river Jagst, } 18 \mathrm{~km} \text { northeast of } \\
\text { Schwäbisch Hall in southern Germany. This area has an oceanic } \\
\text { climate, with warm summer (average high temperature of } \\
24^{\circ} \mathrm{C} \text { ) and cold winter (average low temperature of }-3^{\circ} \mathrm{C} \text { ). }\end{array}$ \\
\hline Italy & Ispra & $\begin{array}{l}\text { IT04 } \\
\text { (EMEP) }\end{array}$ & Suburban & $45.8^{\circ} \mathrm{N}$ & $8.63^{\circ} \mathrm{E}$ & 209 & $\begin{array}{l}\text { Located on the eastern shore of Lake Maggiore, } \sim 60 \mathrm{~km} \text { north- } \\
\text { west of Milan in the northwest Italy. It has an oceanic climate } \\
\text { and is affected by lake breezes. }\end{array}$ \\
\hline Norway & Birkenes & $\begin{array}{l}\text { NO01 } \\
\text { (EMEP) }\end{array}$ & Rural & $58.38^{\circ} \mathrm{N}$ & $8.25^{\circ} \mathrm{E}$ & 190 & $\begin{array}{l}\text { A coastal site } \sim 30 \mathrm{~km} \text { from Kristiansand in southern Norway. } \\
\text { It has an oceanic climate, with summers average daytime tem- } \\
\text { peratures of } 15.7-20.1^{\circ} \mathrm{C} \text { and snowy winters with average tem- } \\
\text { peratures of }-0.9 \text { to } 1.3^{\circ} \mathrm{C} \text {. Annual precipitation is very high } \\
(1380 \mathrm{~mm}) \text {. }\end{array}$ \\
\hline \multirow[t]{3}{*}{ Portugal } & Beato & $\begin{array}{l}\text { PT03070 } \\
\text { (AirBase) }\end{array}$ & $\begin{array}{l}\text { Urban Back- } \\
\text { ground }\end{array}$ & $38.73^{\circ} \mathrm{N}$ & $9.11^{\circ} \mathrm{W}$ & 56 & $\begin{array}{l}\text { A coastal site in Lisbon. Lisbon has a subtropical Mediter- } \\
\text { ranean climate, with mild, rainy winters and warm to hot and } \\
\text { dry summers. Among all the metropolises in Europe, it has the } \\
\text { warmest winters, with average temperatures of } 8-15^{\circ} \mathrm{C} \text {. The } \\
\text { typical summer high temperatures are } 26 \text { to } 34^{\circ} \mathrm{C} \text {. }\end{array}$ \\
\hline & Custóias & $\begin{array}{l}\text { PT01021 } \\
\text { (AirBase) }\end{array}$ & $\begin{array}{l}\text { Suburban } \\
\text { Background }\end{array}$ & $41.20^{\circ} \mathrm{N}$ & $8.65^{\circ} \mathrm{E}$ & 100 & $\begin{array}{l}\text { Located in the Greater Porto area, where the Mediterranean cli- } \\
\text { mate prevails, with warm, dry summers and mild, rainy winters. } \\
\text { Summers average temperatures between } 15 \text { and } 25^{\circ} \mathrm{C} \text {. Winter } \\
\text { temperatures typically range between } 5 \text { and } 15^{\circ} \mathrm{C} \text {. The annual } \\
\text { precipitation is } 1253 \mathrm{~mm} \text {. }\end{array}$ \\
\hline & Ermesinde & $\begin{array}{l}\text { PT01023 } \\
\text { (AirBase) }\end{array}$ & $\begin{array}{l}\text { Suburban } \\
\text { Background }\end{array}$ & $41.21^{\circ} \mathrm{N}$ & $8.55^{\circ} \mathrm{E}$ & 140 & Located $\sim 9 \mathrm{~km}$ northeast of Porto in Portugal. \\
\hline Slovakia & Topolniky & $\begin{array}{l}\text { SK07 } \\
\text { (EMEP) }\end{array}$ & Urban & $47.96^{\circ} \mathrm{N}$ & $17.86^{\circ} \mathrm{E}$ & 113 & $\begin{array}{l}\text { Located in the plain terrain of the Danubian lowlands in north- } \\
\text { western Slovakia. The area has a warm temperate climate. }\end{array}$ \\
\hline Slovenia & Celje & $\begin{array}{l}\text { SI0001A } \\
\text { (AirBase) }\end{array}$ & Urban & $46.24^{\circ} \mathrm{N}$ & $15.27^{\circ} \mathrm{E}$ & 240 & $\begin{array}{l}\text { The third largest town in the east Slovenia. It has a warm tem- } \\
\text { perate climate with warm summers and some rainfall in all } \\
\text { months. The summer high temperatures can reach } 36.8^{\circ} \mathrm{C} \text {, and } \\
\text { the winter low temperature is }-4.7^{\circ} \mathrm{C} \text {. Annual precipitation is } \\
\sim 142 \mathrm{~mm} \text {. }\end{array}$ \\
\hline
\end{tabular}


Table 3. Continued.

\begin{tabular}{|c|c|c|c|c|c|c|c|}
\hline Country & Site name & $\begin{array}{l}\text { Site ID } \\
\text { (network) }\end{array}$ & Site Type & Latitude & Longitude & $\begin{array}{l}\text { Elevation } \\
(\mathrm{m})\end{array}$ & Characteristics \\
\hline \multirow[t]{4}{*}{ Spain } & $\begin{array}{l}\text { Avenida } \\
\text { Gasteiz }\end{array}$ & $\begin{array}{l}\text { ES1502A } \\
\text { (AirBase) }\end{array}$ & Urban & $42.85^{\circ} \mathrm{N}$ & $2.68^{\circ} \mathrm{W}$ & 517 & $\begin{array}{l}\text { Located in northern Spain. It has a mild humid temperate climate with } \\
\text { warm summers and no dry season. The annual summer high tempera- } \\
\text { ture is } 26.7^{\circ} \mathrm{C} \text {, and the winter low temperature is } 1.1^{\circ} \mathrm{C} \text {. }\end{array}$ \\
\hline & $\begin{array}{l}\text { Cabo de } \\
\text { Creus }\end{array}$ & $\begin{array}{l}\text { ES10 } \\
(\text { EMEP) }\end{array}$ & $\begin{array}{l}\text { Kural Back- } \\
\text { ground }\end{array}$ & $42.32^{\circ} \mathrm{N}$ & $3.32^{\circ} \mathrm{W}$ & 23 & $\begin{array}{l}\text { Located in the Cap de Creus peninsula. This region features a Mediter- } \\
\text { ranean climate. Summers are dry and hot with sea breezes, and the max- } \\
\text { imum temperature is around } 26-31^{\circ} \mathrm{C} \text {. Winter is cool or slightly cold } \\
\text { with occasional snow. }\end{array}$ \\
\hline & Els Torms & $\begin{array}{l}\text { ES14 } \\
\text { (EMEP) }\end{array}$ & \multirow{2}{*}{$\begin{array}{l}\text { Rural Back- } \\
\text { ground } \\
\text { Rural Back- } \\
\text { ground }\end{array}$} & $41.40^{\circ} \mathrm{N}$ & $0.72^{\circ} \mathrm{E}$ & 470 & $\begin{array}{l}\text { Located in the province of Catalonia in northeastern Spain. This region } \\
\text { features a Mediterranean climate. }\end{array}$ \\
\hline & Niembro & $\begin{array}{l}\text { ES08 } \\
(\text { EMEP) }\end{array}$ & & $43.44^{\circ} \mathrm{N}$ & $4.85^{\circ} \mathrm{W}$ & 134 & $\begin{array}{l}\text { A beach site in the province of Asturias in northern Spain. It has a mar- } \\
\text { itime climate. Summers are generally humid and warm with some rain. } \\
\text { Winters are cold with some very cold snaps and snow. }\end{array}$ \\
\hline \multirow[t]{4}{*}{ Sweden } & Rörvik & $\begin{array}{l}\text { SE02 } \\
(\text { EMEP) }\end{array}$ & Rural & $57.42^{\circ} \mathrm{N}$ & $11.93^{\circ} \mathrm{E}$ & 10 & $\begin{array}{l}\text { A coastal site located } \sim 40 \mathrm{~km} \text { south of Gothenburg and surrounded by } \\
\text { an open Scots pine forest. It has an oceanic climate. }\end{array}$ \\
\hline & Femman & $\begin{array}{l}\text { SE0004A } \\
\text { (AirBase) }\end{array}$ & Urban & $57.71^{\circ} \mathrm{N}$ & $11.97^{\circ} \mathrm{E}$ & 30 & $\begin{array}{l}\text { A roof site in the Gothenburg. Due to the Gulf Stream, this area has } \\
\text { oceanic climate and frequent rain. Summers are warm with average high } \\
\text { temperatures of } 19 \text { to } 20^{\circ} \mathrm{C} \text {. Winters are cold and windy with temper- } \\
\text { atures of around }-5 \text { to } 3^{\circ} \mathrm{C} \text {. The daytime is } 17 \mathrm{~h} \text {, and the nighttime is } \\
\sim 7 \mathrm{~h} \text { due to a high latitude. }\end{array}$ \\
\hline & Södermalm & $\begin{array}{l}\text { SE0022A } \\
\text { (AirBase) }\end{array}$ & Urban & $59.32^{\circ} \mathrm{N}$ & $18.06^{\circ} \mathrm{E}$ & 20 & See Table 5, Part 1 \\
\hline & Sundsvall & $\begin{array}{l}\text { SE0028A } \\
\text { (AirBase) }\end{array}$ & $\begin{array}{l}\text { Urban } \\
\text { Background }\end{array}$ & $62.39^{\circ} \mathrm{N}$ & $17.31^{\circ} \mathrm{E}$ & 10 & $\begin{array}{l}\text { On the east coast, and middle portion of Sweden. It has a climate on } \\
\text { the border between subarctic and cold continental, with summer high } \\
\text { temperatures of } 21^{\circ} \mathrm{C} \text { and winter low temperature of }-15^{\circ} \mathrm{C} \text {. }\end{array}$ \\
\hline \multirow[t]{2}{*}{$\begin{array}{l}\text { Switzer- } \\
\text { land }\end{array}$} & Chaumont & $\begin{array}{l}\text { CH04 } \\
\text { (EMEP) }\end{array}$ & Rural & $47.05^{\circ} \mathrm{N}$ & $6.98^{\circ} \mathrm{E}$ & 1130 & $\begin{array}{l}\text { In the mountain Chaumont in the city of Neuchâtel. Chaumont has hu- } \\
\text { mid continental climate with warm summer (average high temperature } \\
\text { is } 24.0^{\circ} \mathrm{C} \text { ) and humid with severe winter (average low temperature is } \\
-1.4^{\circ} \mathrm{C} \text { ). }\end{array}$ \\
\hline & Payerne & $\begin{array}{l}\mathrm{CH} 02 \\
(\mathrm{EMEP})\end{array}$ & Suburban & $46.82^{\circ} \mathrm{N}$ & $6.95^{\circ} \mathrm{E}$ & 510 & $\begin{array}{l}\text { In western Switzerland. It has an oceanic climate, with the summer aver- } \\
\text { age high temperature of } 24.1^{\circ} \mathrm{C} \text { and the winter average low temperature } \\
\text { of }-3.3^{\circ} \mathrm{C} \text {. Payerne has an average of } 116.4 \text { days of rain or snow per } \\
\text { year and on average receives } 845 \mathrm{~mm} \text { of precipitation, with August the } \\
\text { wettest and February the driest. }\end{array}$ \\
\hline \multirow[t]{3}{*}{ UK } & Harwell & $\begin{array}{l}\text { GB0036R } \\
\text { (AirBase) }\end{array}$ & Rural & $51.57^{\circ} \mathrm{N}$ & $1.32^{\circ} \mathrm{W}$ & 137 & $\begin{array}{l}\text { Located } \sim 81 \mathrm{~km} \text { northwest of London in southern UK. It has a mar- } \\
\text { itime temperate climate. }\end{array}$ \\
\hline & $\begin{array}{l}\text { Rochester } \\
\text { Stoke }\end{array}$ & $\begin{array}{l}\text { GB0617A } \\
\text { (AirBase) }\end{array}$ & Rural & $51.46^{\circ} \mathrm{N}$ & $0.63^{\circ} \mathrm{E}$ & 14 & $\begin{array}{l}\text { Located in the city of Rochester in the southeastern corner of England, } \\
\text { UK. It has a maritime temperate climate, one of the warmest parts of } \\
\text { UK, with summer average high temperature of } 21.9^{\circ} \mathrm{C} \text { and winter av- } \\
\text { erage lower temperature of } 1.7^{\circ} \mathrm{C} \text {. }\end{array}$ \\
\hline & $\begin{array}{l}\text { London } \\
\text { Bloomsbury }\end{array}$ & $\begin{array}{l}\text { GB0566A } \\
\text { (AirBase) }\end{array}$ & $\begin{array}{l}\text { Urban Back- } \\
\text { ground }\end{array}$ & $51.52^{\circ} \mathrm{N}$ & $0.12^{\circ} \mathrm{W}$ & 20 & See Table 5, Part 1 \\
\hline
\end{tabular}

of ISOP, terpenes (TERP), $\mathrm{HCHO}, \mathrm{OH}, \mathrm{O}_{3}, \mathrm{SOA}$, anthropogenic SOA (ASOA), and $\mathrm{PM}_{2.5}$ from the simulation WC-S and the absolute differences in these concentrations between WC-G and WC-S, and between WC-M and WC-S over D01 in July 2001. WC-S gives the highest BVOC emissions domainwide, leading to the highest domainwide concentrations of BVOCs, $\mathrm{HCHO}$, higher aldehydes, and $\mathrm{HO}_{2}$, which in turn lead to the highest domainwide concentrations of $\mathrm{O}_{3}$, SOA, ASOA, and $\mathrm{PM}_{2.5}$. Compared to WC-G, WC-M gives higher TERP and ISOP emissions over most areas, leading to higher HCHO concentrations for almost the whole domain. Although WC-M gives lower terpene concentrations in Sweden, Finland, and a portion of Russia, it produces higher terpene concentrations over the rest of domain, leading to higher domain-average concentrations of terpene than WCG. High $\mathrm{HO}_{2}$ concentrations resulting from higher $\mathrm{HCHO}$ and TERP convert more $\mathrm{NO}$ to $\mathrm{NO}_{2}$, leading to higher $\mathrm{O}_{3}$ by WC-M than by WC-G. On the other hand, higher BVOC emissions from WC-M consume more $\mathrm{OH}$, lead- ing to slightly lower $\mathrm{OH}$ concentrations, thus slightly lower domain-average concentrations of ISOP, SOA, and $\mathrm{PM}_{2.5}$ (despite higher concentrations of SOA and $\mathrm{PM}_{2.5}$ in some areas such as Romania, Ukraine, and Belarus). The SOA formation is dominated by biogenic SOA (BSOA) in the whole domain, with very small contributions from ASOA in a few areas. Different BVOC emissions will thus affect mostly biogenic SOA, although they also affect the formation of ASOA through affecting oxidants and radicals. For example, compared to the simulation with offline BVOCs, the simulation using MEGAN BVOC module gives lower SOA and BSOA concentrations, by $1.32 \mu \mathrm{g} \mathrm{m}^{-3}$ domainwide mean $(-30 \%)$ and as low as $-9.7 \mu \mathrm{g} \mathrm{m}^{-3}$ (by $-92.5 \%$ ), and it gives lower ASOA concentrations, by $0.009 \mu \mathrm{g} \mathrm{m}^{-3}$ domainwide mean and as low as $0.06 \mu \mathrm{g} \mathrm{m}^{-3}$. Spatially, ISOP and TERP correlate well with SOA, which is an important contributor for $\mathrm{PM}_{2.5}$ over regions with high BVOC emissions. Table 1 compares performance statistics of WRF/Chem-MADRID using three different BVOC modules over D01. The performance 

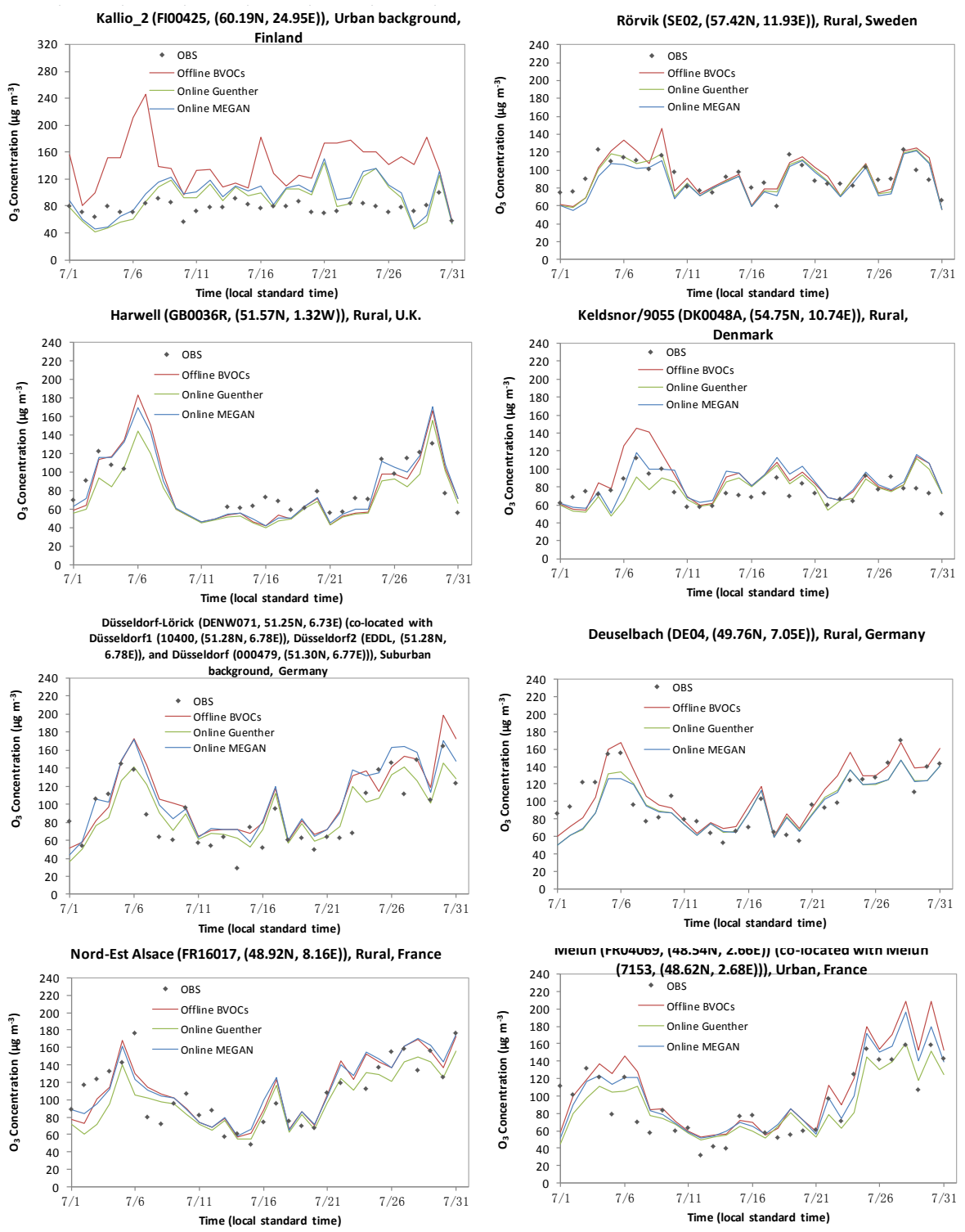

Fig. 12. Simulated and observed concentrations of $\max 8 \mathrm{~h} \mathrm{O} 3$ over D01 from WRF/Chem-MADRID using offline BVOC emissions of Simpson et al. (1999) and online BVOC emission modules based on modified Guenther (Guenther et al., 1995) and MEGAN (Guenther et al., 2006) in July 2001 at selected sites over D01.

statistics is overall similar. WC-S gives slightly better agreement in terms of $\mathrm{NMBs}$ for $\mathrm{NH}_{3}, \mathrm{HNO}_{3}$, hourly $\mathrm{NO}_{2}$, maximum $1 \mathrm{~h} \mathrm{O}_{3}$ at the EMEP sites, daily $\mathrm{PM}_{10}$ at the EMEP sites, daily $\mathrm{SO}_{4}^{2-}$, daily $\mathrm{NO}_{3}^{-}$at the EMEP sites, $\mathrm{NO}_{3}^{-}, \mathrm{NH}_{4}^{+}$, $\mathrm{Na}^{+}$, and $\mathrm{Cl}^{-}$at the AirBase sites, and column $\mathrm{NO}_{2}$. WC-G gives slightly better agreement in terms of NMBs for hourly $\mathrm{SO}_{2}$, daily $\mathrm{NO}_{2}$, maximum $8 \mathrm{~h} \mathrm{O}$ at the AirBase and EMEP sites, hourly $\mathrm{PM}_{10}$ at the BDQA sites, daily $\mathrm{NO}_{3}^{-}$at the AirBase sites, column $\mathrm{CO}$, and $\mathrm{AOD}$, and $\mathrm{WC}-\mathrm{M}$ gives slightly better agreement in terms of NMBs for daily $\mathrm{SO}_{2}$, maximum $1 \mathrm{~h} \mathrm{O}_{3}$ at the AirBase and BDQA sites, maximum $8 \mathrm{~h} \mathrm{O}$ at the BDQA sites, hourly $\mathrm{PM}_{2.5}$ and $\mathrm{PM}_{10}$ at the AirBase sites, daily $\mathrm{Cl}^{-}$at the EMEP sites, and TOR. WC-G gives much better hourly $\mathrm{O}_{3}$ performance than the other two simulations. WC-S and WC-G give the same agreement for daily $\mathrm{PM}_{2.5}$ at the EMEP sites. Among the species evaluated, those that are relatively more sensitive to different BVOC modules include $\mathrm{HNO}_{3}$, hourly and maximum $8 \mathrm{~h} \mathrm{O}$, hourly $\mathrm{PM}_{2.5}$, $\mathrm{SO}_{4}^{2-}, \mathrm{NO}_{3}^{-}, \mathrm{NH}_{4}^{+}$, and AOD.

Figures 12-13 show observed and simulated temporal variations of maximum $8 \mathrm{~h} \mathrm{O} 3$ and $24 \mathrm{~h} \mathrm{PM}_{2.5}$ concentrations at specific sites from the three simulations using WRF/Chem-MADRID with different BVOC emissions. $\mathrm{O}_{3}$ formation is very sensitive to BVOC emissions at Kallio 

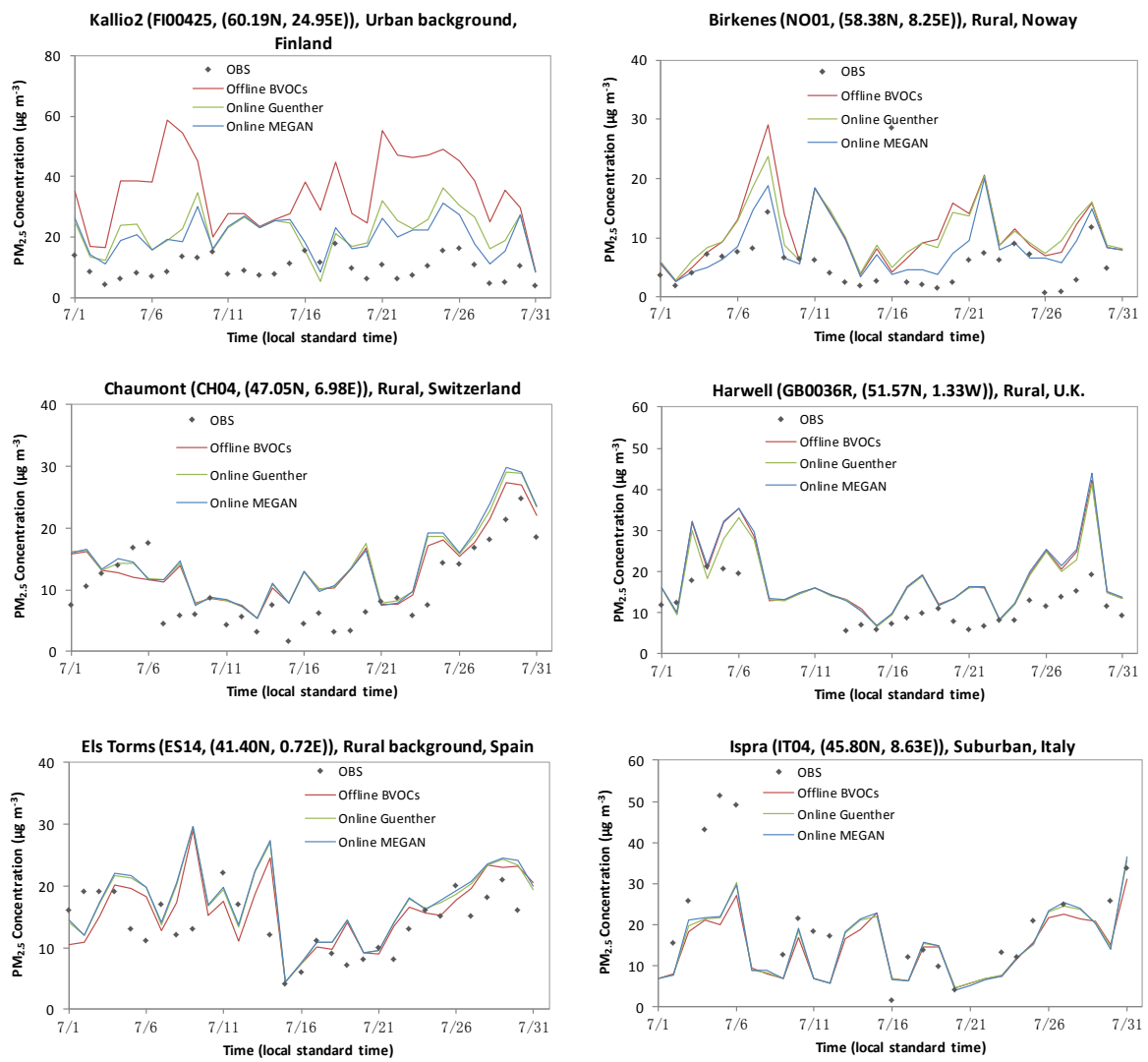

Fig. 13. Simulated and observed concentrations of $24 \mathrm{~h}$ average $\mathrm{PM}_{2.5}$ over D01 from WRF/Chem-MADRID using offline BVOC emissions of Simpson et al. (1999) and online BVOC emission modules based on modified Guenther (Guenther et al., 1995) and MEGAN (Guenther et al., 2006) in July 2001 at selected sites over D01.

in Finland, moderately sensitive at Rörvik, Sweden, Keldsnor/9055 in Denmark, Deuselbach in Germany, and Melun in France, and slightly sensitive at the remaining sites. WC$\mathrm{S}$ tends to overpredict maximum $8 \mathrm{~h} \mathrm{O}_{3}$ at all sites except for Deuselbach, where it gives the best agreement with observations among the three simulations. WC-G gives the best agreement at Rörvik, Harwell, Düsseldorf-Lörick, Kallio_2, and Melun. WC-M gives the best agreement at Keldsnor/9055 and Nord-Est Alsace. The 24 h PM 2.5 concentrations are also very or moderately sensitive to BVOC emissions at some sites (e.g., Kallio_2 and Birkenes), although they are slightly sensitive at the remaining sites. While WC$\mathrm{S}$ significantly overpredicts $\mathrm{PM}_{2.5}$ concentrations at Kallio_2 and Birkenes, it gives an overall best agreement at Chaumont and Els Torms. WC-M gives the best agreement at Kallio_2 and Birkenes. The simulations with the three different BVOCs give similar results at Harwell and Ispra.

\section{Impact of aerosols on gaseous pollutant predictions}

As shown in Fig. 14, the emissions of primary $\mathrm{SO}_{4}^{2-}$ and $\mathrm{NO}_{3}^{-}$, and gaseous precursors for secondary aerosol lead to high concentrations of $\mathrm{NH}_{4}^{+}, \mathrm{SO}_{4}^{2-}$ and $\mathrm{NO}_{3}^{-}$in the whole domain. Their formation would affect the levels of oxidants and radicals available for oxidation of gaseous species, as they compete for the same sets of oxidants and radicals. As shown in Fig. 5 in Part 1, those secondary aerosols together with primary aerosols can affect many meteorological variables in different ways. The changes in meteorological variables due to aerosol-meteorology interactions in turn affect the chemical predictions of gaseous concentrations in the next time step. Fig. 14 also shows the impact of aerosols on gaseous predictions through secondary aerosol formation processes and aerosol-meteorology interactions. For example, in the presence of PM, the CO concentrations are higher due to reduced WS10, reduced PBL height, and a lower amount of $\mathrm{OH}$ radicals available for its oxidation as a result of competitive consumption of these radicals by PM precursors to form secondary aerosols. As a result of a similar competition, the concentrations of $\mathrm{O}_{3}$ are lower due to a lower amount of radicals (e.g., $\mathrm{OH}$ and $\mathrm{HO}_{2}$ ) available to oxidize the precursors of $\mathrm{O}_{3}$. The concentrations of $\mathrm{NH}_{3}$ and $\mathrm{HNO}_{3}$ are lower due to a higher amount of $\mathrm{NH}_{4} \mathrm{NO}_{3}$ formation that compensates their potential increase caused by a reduced PBL height. The concentrations of $\mathrm{SO}_{2}$ are 


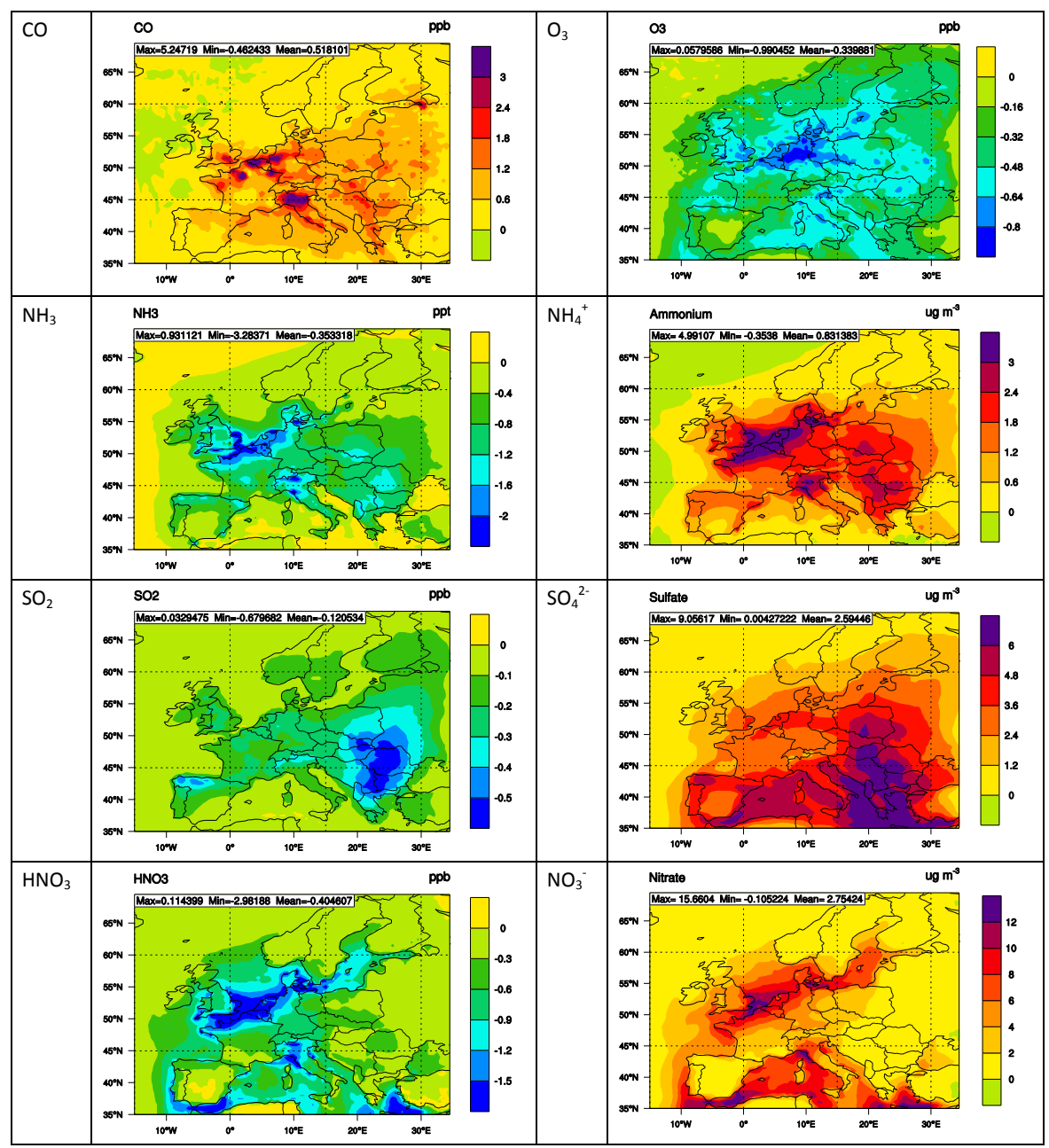

Fig. 14. Simulated changes in chemical composition in the presence of aerosol by WRF/Chem-MADRID in July 2001 over D01.

lower due to a higher conversion rate to form $\mathrm{SO}_{4}^{2-}$ that resulted from increased temperature. These results caused by secondary aerosol formation and meteorology-chemistry interactions are consistent with the simulated aerosol effects using GU-WRF/Chem over the global domain and nested domains over North America and East Asia reported by Zhang et al. (2012b).

\section{Conclusions}

In this Part 2, the offline-coupled model (WRF/Polyphemus) and the online-coupled model (WRF/Chem-MADRID) are applied to simulate air quality in July 2001 at horizontal grid resolutions of $0.5^{\circ}$ and $0.125^{\circ}$ over Western Europe. To minimize differences caused by model inputs, both models use the same version of WRF to generate meteorological predictions and the same anthropogenic emissions. They also use the same model mechanisms (e.g., CB05 for gas-phase mechanism, Fast-J for photolysis scheme, and
Carnegie Mellon University (CMU) mechanism for aqueousphase chemistry). Differences remain in their vertical structures (e.g., heights of the first model layer, thickness of each layer, and the total number of model layers), chemical initial and boundary conditions, emissions of dust and sea salt, heterogeneous chemistry, dry and wet deposition, aerosol treatments, and aerosol-cloud interactions. A comprehensive model evaluation is performed to evaluate the model's performance using three surface monitoring stations including EMEP, AirBase, and BDQA and several satellite databases including MOPPIT, GOME, TOMS, and MODIS.

For domainwide statistical performance at $0.5^{\circ}$, compared with WRF/Polyphemus, WRF/Chem-MADRID gives higher domainwide mean values for all surface concentrations and column variables except for hourly $\mathrm{O}_{3}$ and TOR (which differs substantially due to the use of different upper layer boundary conditions). Compared with observations, WRF/Polyphemus gives better statistical performance for daily $\mathrm{HNO}_{3}, \mathrm{SO}_{2}$, and $\mathrm{NO}_{2}$ at the EMEP sites, maximum $1 \mathrm{~h}$ $\mathrm{O}_{3}$ at the AirBase sites, maximum $8 \mathrm{~h} \mathrm{O}_{3}$ at all sites, $\mathrm{PM}_{2.5}$ 
at the AirBase sites, $\mathrm{PM}_{10}$ composition, column abundance of $\mathrm{CO}, \mathrm{NO}_{2}$, and TOR, and $\mathrm{AOD}$, whereas WRF/ChemMADRID outperforms for $\mathrm{NH}_{3}$, hourly $\mathrm{SO}_{2}, \mathrm{NO}_{2}$, and $\mathrm{O}_{3}$ at the AirBase and BDQA sites, maximum $1 \mathrm{~h} \mathrm{O}_{3}$ at the BDQA and EMEP sites, and $\mathrm{PM}_{10}$ at all sites. For spatial distribution at $0.5^{\circ}$, compared with WRF/Polyphemus, WRF/ChemMADRID gives higher values over most of the domain, in particular, over polluted regions in Central and southern Europe for all surface concentrations and column variables except for TOR. The model performance in terms of temporal variation varies from site to site, depending on the latitude bands, topography, meteorological and climate conditions, and source of pollutants. For temporal distributions of $\mathrm{SO}_{2}$, WRF/Chem-MADRID reproduces well the observed high concentrations at urban and suburban sites except for extremely high episodes at a few sites, and WRF/Polyphemus performs well at rural and some background sites where pollutant levels are relatively low. For temporal distributions of $\mathrm{NO}_{2}, \mathrm{WRF} / \mathrm{Chem}-\mathrm{MADRID}$ reproduces well the observed concentrations at most sites, whereas WRF/Polyphemus underpredicts them at most sites. For temporal distributions of $\mathrm{O}_{3}$, both models generally capture well the daytime maximum $8 \mathrm{~h} \mathrm{O}_{3}$ concentrations at all sites except for urban/suburban background sites where both models overpredict the observations. They both generally simulate well the diurnal variations of $\mathrm{O}_{3}$ with more accurate peak daytime and minimal nighttime values by WRF/Chem-MADRID, but neither model reproduces extremely low nighttime $\mathrm{O}_{3}$ concentrations at several urban and suburban sites due to underpredictions of $\mathrm{NO}_{\mathrm{x}}$ and thus insufficient titration of $\mathrm{O}_{3}$ at night. For temporal distributions of $\mathrm{PM}_{2.5}$, WRF/Polyphemus gives more accurate predictions in terms of magnitudes, and WRF/Chem-MADRID overpredicts at all sites. For temporal distributions of $\mathrm{PM}_{10}$, WRF/Chem-MADRID reproduces reasonably well the observations at all sites but due mainly to the overpredictions of $\mathrm{PM}_{2.5}$, whereas WRF/Polyphemus significantly underpredicts them. The predictions of column variables differ significantly between the two models. WRF/Polyphemus gives relatively good performance for column $\mathrm{CO}$ and $\mathrm{NO}_{2}$ in terms of domainwide statistics, but fails to reproduce high observed column $\mathrm{CO}$ concentrations in most regions. WRF/Chem-MADRID significantly overpredicts column $\mathrm{CO}$ and $\mathrm{NO}_{2}$ but captures better their high column mass concentrations. WRF/Polyphemus gives much higher TOR than WRF/Chem-MADRID, but neither model captures the observed magnitudes of TOR. Both models significantly overpredict AOD.

These differences in model predictions of gaseous pollutants and $\mathrm{PM}_{2.5}$ are caused by differences in vertical structure that causes differences in vertical distributions of emissions, boundary conditions of some species (e.g., $\mathrm{O}_{3}$ and $\mathrm{CO}$ ), heterogeneous chemistry, dry and wet deposition treatments of gases (e.g., $\mathrm{SO}_{2}$ and $\left.\mathrm{NO}_{2}\right)$ and $\mathrm{PM}$ species $\left(\mathrm{SO}_{4}^{2-}, \mathrm{NO}_{3}^{-}\right.$, $\mathrm{NH}_{4}^{+}, \mathrm{BC}$, and $\mathrm{TOM}$ ), aerosol treatments such as inorganic aerosol thermodynamics and SOA, as well as aerosol-cloud interactions used in both models. Additional differences in $\mathrm{PM}_{2.5}$ and $\mathrm{PM}_{10}$ predictions are due to the fact that the two models use different boundary conditions for dust particles and sea-salt emission modules, and WRF/Chem-MADRID uses an online soil dust emission module that is not included in WRF/Polyphemus. The inclusion of soil dust emissions allows a better representation of $\mathrm{PM}_{10}$ concentrations. The differences between model predictions and observations are mostly caused by inaccurate representations of emissions of gaseous precursors such as $\mathrm{SO}_{2}, \mathrm{NO}_{2}$, and VOCs and primary PM such as EC and POC during the high pollution episodes in the EMEP emission inventories. Both models fail to reproduce nighttime $\mathrm{O}_{3}$ levels, due mainly to underpredictions in $\mathrm{NO}_{\mathrm{x}}$ emissions and thus insufficient titration of nighttime $\mathrm{O}_{3}$ under the high- $\mathrm{NO}_{\mathrm{x}}$ conditions and missing mechanisms of $\mathrm{O}_{3}$ destruction such as the heterogeneous reactions of sea salt in the models under the low- $\mathrm{NO}_{\mathrm{x}}$ conditions. Some of the differences between chemical predictions and observations can also be attributed to biases in the meteorological predictions such as $2 \mathrm{~m}$ temperature and $10 \mathrm{~m}$ wind speed.

Both models show some sensitivity to horizontal grid resolutions, in particular, at mountain/high altitude sites and sites with complex terrain. Compared with WRF/Polyphemus, WRF/Chem-MADRID shows a higher sensitivity to grid resolutions at all sites. For both models, the use of a finer grid resolution generally leads to an overall better statistical performance for most variables, with greater details in areas having high or low concentrations and an overall better agreement in temporal variations and magnitudes at most sites. The use of a finer grid resolution, however, does not always improve model performance due to the limitation of current meteorological models in capturing fine-scale atmospheric processes and the lack of information for a more accurate representation of emissions and land use data at a finer grid scale.

Different BVOC emission modules generate significantly different BVOC emissions in terms of magnitudes of total emissions and their spatial distributions, which in turn affect chemical predictions. WRF/Chem-MADRID sensitivity simulations show moderate to large differences in predicted concentrations of BVOCs, $\mathrm{HCHO}, \mathrm{OH}, \mathrm{O}_{3}, \mathrm{SOA}$, and $\mathrm{PM}_{2.5}$ between the offline and online emissions but a similarity between the simulations with the two online BVOC emission modules. The use of online BVOC emissions gives better statistical performance for hourly and maximum $8 \mathrm{~h} \mathrm{O}_{3}$ and $\mathrm{PM}_{2.5}$ and generally better agreement with their observed temporal variations at most sites.

Therefore, it appears that major sources of uncertainties in current state-of-the-science air quality models are the vertical structure of the models (i.e., heights of the first model layer, thickness of each layer, and the total number of model layers), inputs (i.e., vertical distributions of emissions, natural emissions of dust, sea salt, and BVOCs, and boundary 
conditions) and removal (i.e., dry and wet deposition rates of gases and particles) of pollutants. These results suggest that, on the one hand, the transport and transformation processes of most pollutants are mostly well represented, but that, on the other hand, experimental data on emissions (in particular, the vertical distribution of emissions) and deposition are in dire need of refinement if one wants to improve model performance. In addition, boundary conditions generated using different models may introduce large differences, in particular, the column mass abundance of chemical species such as $\mathrm{O}_{3}$ and $\mathrm{CO}$.

As an online-coupled meteorology-chemistry model, WRF/Chem-MADRID can simulate various feedbacks between meteorology and chemical species. Such feedbacks can in turn affect chemical predictions of all species. These results are consistent in sign but smaller in terms of magnitudes as compared with the simulated aerosol effects found by previous studies over other regions of the world, such as East Asia and North America.

Acknowledgements. This project is sponsored by the EPA STAR \#R83337601, the NSF/USDA EaSM program AGS-1049200, and the fellowship award \#704389J, the Atmospheric Environment Center (CEREA)/École des Ponts ParisTech, France, through a visiting professorship of Y. Zhang at CEREA, the Joint Laboratory of École des Ponts ParisTech and EDF R\&D, Paris, France, and COST ES1004. Thanks are due to contributions of former members of the air quality forecasting laboratory at NCSU, including Yao-Sheng Chen, Xu-Yan Liu, and Ryan Cassidy for preparing some inputs for WRF/Chem-MADRID, processing data, and making plots. Thanks are also due to Yiguo Wang, CEREA, for his help in using the AirBase data.

Edited by: F. Yu

\section{References}

Anttila, P. and Salmi, T.: Characterizing temporal and spatial patterns of urban $\mathrm{PM}_{10}$ using six years of Finnish monitoring data, Boreal. Environ. Res., 11, 463-479, 2006.

Aphesis (Air Pollution and Health: A European Information System): Health impact assessment of air pollution In 26 European Cities, ENHIS-1 Project: WP5 Health impact assessment, Second-year Report, 2000-2001, http://www.apheis.org/index. html, 2006.

Arunachalam, S., Holland, A., Do, B., and Abraczinskas, M.: A quantitative assessment of the influence of grid resolution on predictions of future-year air quality in North Carolina, USA, Atmos. Environ., 40, 5010-5026, 2006.

Bailey, E. M., Gautney, L. L., Kelsoe, J. J., Jacobs, M. E., Condrey, J.W., Pun, B., Wu, S.-Y., Seigneur, C., Douglas, S., Haney, J., and Kumar, N.: A comparison of the performance of four air quality models for the Southern Oxidants Study episode in July 1999, J. Geophys. Res., 112, D05306, doi:10.1029/2005JD007021, 2007.
Barmpadimos, I., Keller, J., Oderbolz, D., Hueglin, C., and Prévôt, A. S. H.: One decade of parallel fine $\left(\mathrm{PM}_{2.5}\right)$ and coarse $\left(\mathrm{PM}_{10}-\mathrm{PM}_{2.5}\right)$, particulate matter measurements in Europe: trends and variability, Atmos. Chem. Phys., 12, 3189-3203, doi:10.5194/acp-12-3189-2012, 2012.

Chin, M., Rood, R., Lin, S.-J., Muller, J., Thompson, A.: Atmospheric sulfur cycle in the global model GOCART: model description and global properties, J. Geophys. Res., 105, 2467124687, 2000.

Cohan, D. S., Hu, Y., and Russell, A.G.: Dependence of ozone sensitivity analysis on grid resolution, Atmos. Environ., 40, 126135, 2006.

de Meij, A., Krol, M., Dentener, F., Vignati, E., Cuvelier, C., and Thunis, P.: The sensitivity of aerosol in Europe to two different emission inventories and temporal distribution of emissions, Atmos. Chem. Phys., 6, 4287-4309, doi:10.5194/acp-6-4287-2006, 2006.

Fast, J. D., Gustafson Jr., W. I., Easter, R. C., Zaveri, R. A., Barnard, J. C., Chapman, E. G., Grell, G. A., and Peckham, S. E.: Evolution of ozone, particulates, and aerosol direct radiative forcing in the vicinity of Houston using a fully coupled meteorology-chemistry-aerosol model, J. Geophys. Res., 111, D21305, doi:10.1029/2005JD006721, 2006.

Forkel, R., Werhahn, J., Hansen, A. B., McKeen, S., Peckham, S., Grell, G., and Suppan, P.: Effect of aerosol-radiation feedback on regional air quality - A case study with WRF/Chem, Atmos. Environ., 53, 202-211, 2012.

Guenther, A., Zimmerman, P., Harley, P., Monson, R., and Fall, R.: Isoprene and monoterpene emission rate variability: model evaluation and sensitivity analysis, J. Geophys. Res, 98, 1260912617, 1993.

Guenther, A., Baugh, B., Brasseur, G., Greenberg, J., Harley, P., Klinger, L., Serca, D., and Vierling, L.: Isoprene emission estimates and uncertainties for the Central African EXPRESSO study domain, J. Geophys. Res.-Atmos., 104, 30625-30639, 1999.

Guenther, A., Karl, T., Harley, P., Wiedinmyer, C., Palmer, P. I., and Geron, C.: Estimates of global terrestrial isoprene emissions using MEGAN (Model of Emissions of Gases and Aerosols from Nature), Atmos. Chem. Phys., 6, 3181-3210, doi:10.5194/acp-63181-2006, 2006.

Haeger-Eugensson, M., Moldanova, J., Ferm, M., Jerksjo, M., and Fridell, E.: On the increasing levels of $\mathrm{NO}_{2}$ in some cities: the role of primary emissions and shipping, Final project report, IVL Report B1886. IVL Swedish Environmental Research Institute Ltd., SE-400 14 Gothenburg, Sweden, 2010.

Jacobson, M. Z.: Air Pollution and Global Warming: History, Science, and Solutions, Cambridge University Press, New York, 2012, 406 pp., 2nd Edn., ISBN 110769115X, 2012.

Johansson, C. and Forsberg, B.: Kvävedioxid och ozon i tätortsluften. Halternas samspel samt konsekvenser för hälsan. Naturvårdsverket, 10648 Stockholm, rapport 5519. ISBN 91620-5519-4, 2005.

Karppinen, A., Härkönen, J., Kukkonen, J., Aarnio, P., and Koskentalo, T.: Statistical model for assessing the portion of fine particulate matter transported regionally and long range to urban air, Scand. J. Work Env. Hea., 30, 47-53, 2004.

Karppinen, A., Härkönen, J., Kukkonen, J., Aarnio, P., and Koskentalo, T.: Statistical model for assessing the portion of fine partic- 
ulate matter transported regionally and long range to urban air, Scand. J. Work. Env. Hea., 30, 47-53, 2004.

Kauhaniemi, M., Karppinen, A., Härkönen, J., Kousa, A., Koskentalo, T., Aarnio, P., and Kukkonen, J.: Refinement and statistical evaluation of a modelling system for predicting fine particle concentrations in urban areas, in: Proceedings of the 6th International Conference on Urban Air Quality, edited by: Sokhi, R. S. and Neophytou, M., Limassol, Cyprus, 27-29 March 2007, CDdisk: ISBN 978-1-905313-46-4, University of Hertfordshire and University of Cyprus, 68-71, 2007.

Kim, Y., Sartelet K., and Seigneur C.: Comparison of two gas-phase chemical kinetic mechanisms of ozone formation over Europe, J. Atmos. Chem., 62, 89-119, 2009.

Kim, Y., Sartelet, K., and Seigneur, C.: Formation of secondary aerosols over Europe: comparison of two gas-phase chemical mechanisms, Atmos. Chem. Phys., 11, 583-598, doi:10.5194/acp-11-583-2011, 2011.

Liu, X.-H., Zhang, Y., Cheng, S.-H., Xing, J., Zhang, Q., Streets, D. G., Jang, C. J., Wang, W.-X., and Hao, J.-M.: Understanding of Regional Air Pollution over China using CMAQ: - Part 1 Performance Evaluation and Seasonal Variation, Atmos. Environ., 44, 2415-2426, 2010.

MacCarthy, J., Thistlethwaite, G., Salisbury, E., Pang, Y., and Misselbrook, T.: Air Quality Pollutant Inventories for England, Scotland, Wales and Northern Ireland: 1990 2010, A report of the National Atmospheric Emissions Inventory, AEA Group, http://uk-air.defra.gov.uk/reports/cat07/ 1209130947_DA_AQPI_2010_MainBody_v1.pdf, 2012.

Mallet, V. and Sportisse, B.: Uncertainty in a chemistry-transport model due to physical parameterizations and numerical approximations: An ensemble approach applied to ozone modeling, J. Geophys. Res., 111, D01302, doi:10.1029/2005JD006149, 2006.

Mathur, R., Shankar, U., Hanna, A. F., Odman, M. T., McHenry, J. N., Coats Jr., C. J., Alapaty, K., Xiu, A., Arunachalam, S., Olerud Jr., D. T., Byun, D. W., Schere, K. L., Binkowski, F. S., Ching, J. K. S., Dennis, R. L., Pierce, T. E., Pleim, J. E., Roselle, S. J., and Young, J. O.: Multiscale Air Quality Simulation Platform (MAQSIP): Initial applications and performance for tropospheric ozone and particulate matter, J. Geophys. Res., 110, D13308, doi:10.1029/2004JD004918, 2005.

Monks, P. S.: Gas-phase radical chemistry in the troposphere, Chem. Soc. Rev., 34, 376-395, 2005.

Norman, M. and Johansson, C.: Studies of some measures to reduce road dust emissions from paved roads in Scandinavia, Atmos. Environ., 40, 6154-6164, 2006.

Otorepec, P. and Gale, T.: CELJE CITY REPORT, in 2004 ENHIS1 City Reports, European APHEIS project, Institute of Public Health of the Republic of Slovenia, Ljubljana, Slovenia, available at: http://www.apheis.org/ApheisNewCityReports1.PDF/ index.html, 2004.

Øystein, H., Sorteberg, A., Schmidbauer, N., Solberg, S., Stordal, F., Simpson, D., Lindskog, A., Areskoug, H., Oyola, P., Lättilä, H., and Heidam, N. Z.: European VOC Emission Estimates Evaluated by Measurements and Model Calculations, J. Atmos. Chem., 28, 173-193, 1997.

Pakkanen, T. A., Loukkola, K., Korhonen, C. H., Aurela, M., Mäkela, T., Hillamo, R. E., Aarnio, P., Koskentalo, T., Kousa, A., and Maenhaut, W.: Sources and chemical composition of atmospheric fine and coarse particles in the Helsinki area, Atmos.
Environ., 35, 5381-5391, 2001b.

Pay, M. T., Jiménez-Guerrero, P., and Baldasano, J. M.: Implementation of resuspension from paved roads for the improvement of CALIOPE air quality system in Spain, Atmos. Environ., 45, 802807, 2011.

Péré, J. C., Mallet, M., Pont, V., and Bessagnet, B.: Impact of aerosol direct radiative forcing on the radiative budget, surface heat fluxes, and atmospheric dynamics during the heat wave of summer 2003 over western Europe: A modeling study, J. Geophys. Res., 116, D23119, doi:10.1029/2011JD016240, 2011.

Perrino, C. and Putaud, J.-P.: long-term trends in atmospheric pollution in Italy - assessment of the EMEP measurements and modeling work in Europe from 1977 until today, EUR 20979 EN, pp. 19, all also available on the JRC/IES/CCU world wide web site at: http://ccu.ei.jrc.it/ccu/, 2003.

Putaud, J.P., Raes, F., Van Dingenen, R., Bruggemann, E., Facchini, M.C., Decesari, S., Fuzzi, S., Gehrig, R., Huglin, C., Laj, P., Lorbeer, G., Maenhaut, W., Mihalopoulos, N., Mulller, K., Querol, X., Rodriguez, S., Schneider, J., Spindler, G., ten Brink, H., Torseth, K. and Wiedensohler, A.: A European aerosol phenomenology-2: chemical characteristics of particulate matter at kerbside, urban, rural and background sites in Europe, Atmos. Environ., 38, 2579-2595, 2004.

Queen, A. and Zhang, Y.: Examining the sensitivity of MM5CMAQ predictions to explicit microphysics schemes and horizontal grid resolutions, Part III - The impact of horizontal grid resolution, Atmos. Environ., 42, 3869-3881, 2008.

Real, E. and Sartelet, K.: Modeling of photolysis rates over Europe: impact on chemical gaseous species and aerosols, Atmos. Chem. Phys., 11, 1711-1727, doi:10.5194/acp-11-1711-2011, 2011.

Ribeiro, I., Cascão, P., Monteiro, A., Lopes, M., Tavares, R., Figueira de Sousa, J., Miranda, A.I., and Borrego, C.: The impact of biodiesel on air pollutant emissions: Northern Portugal case study, In the IAIA12 Conference Proceedings' Energy Future The Role of Impact Assessment 32nd Annual Meeting of the International Association for Impact Assessment 27 May-1 June 2012, Centro de Congresso da Alfândega, Porto - Portugal, 2012.

Roustan, Y., Sartelet, K. N., Tombette, M., Debry, É., and Sportisse, B.: Simulation of aerosols and gas-phase species over Europe with the WRF/Polyphemus system. Part II: Model sensitivity analysis for 2001, Atmos. Environ., 44, 4219-4229, 2010.

Sartelet, K., Hayami, H., and Sportisse, B.: MICS-Asia Phase I: Model-to-data comparison for 2001, Atmos. Environ., 41, 61166131, doi:10.1016/j.atmosenv.2007.03.005, 2007.

Sartelet, K. N., Couvidat, F., Seigneur, C., and Roustan, Y.: Impact of biogenic emissions on air quality over Europe and North America, Atmos. Environ., 53, 131-141, 2012.

Simpson, D., Winiwarter, W., Brjesson, G., Cinderby, S., Ferreiro, A., Guenther, A., Hewitt, C., Janson, R., Khalil, M., Owen, S., Pierce, T., Puxbaum, H., Shearer, M., Skiba, U., Steinbrecher, R., Tarrason, L., Oquist, M.: Inventorying emissions from nature in Europe, J. Geophys. Res., 104, 8113-8152, 1999.

SLB-analys: The Stockholm Trial, Effects on air quality and health, ISSN 1400-0806, City of Stockholm Environment and Health Administration, Tekniska nämndhuset, Fleminggatan 4. Box 8136 SE-104 20 Stockholm SWEDEN, 2006.

Sogacheva, L., Dal Maso, M., Kerminen, V.-M. and Kulmala, M.: Probability of nucleation events and aerosol particle 
concentration in different air mass types arriving at Hyytiälä, southern Finland, based on back trajectories analysis, Boreal Environ. Res., 10, 479-491, 2005.

Tang, L., Chen, D., Karlsson, P.-E., Gu, Y., and Ou, T.: Synoptic circulation and its influence on spring and summer ozone concentrations in southern Sweden, Boreal Env. Res., 14, 889-902, 2009.

Tervahattu, H., Kupiainen, K.J., Räisänen, M., Mäkelä, T., and Hillamo, R.: Generation of urban road dust from anti-skid and asphalt concrete aggregates, J. Hazard. Mater, 132, 39-46, 2006.

Tuccella, P., Curci, G., Visconti, G., Bessagnet, B., Menut, L., and Park, R. J.: Modeling of gas and aerosol with WRF/Chem over Europe: Evaluation and sensitivity study, J. Geophys. Res., 117, D03303, doi:10.1029/2011JD016302, 2012.

Valari, M. and Menut, L.: Does an increase in air quality models' resolution bring surface ozone concentrations closer to reality?, J. Atmos. Oceanic Technol., 25, 1955-1968, 2008.

Vallius, M., Lanki, T., Tiittanen, P., Koistinen, K., Ruuskanen, J. and Pekkanen, J., Source apportionment of urban ambient $\mathrm{PM}_{2.5}$ in two successive measurement campaigns in Helsinki, Finland, Atmos. Environ., 37, 615-623, 2003.

van Aardenne, J. A., Dentener, F. J., Olivier, J. G. J., Peters, J. A. H. W. and Ganzeveld, L. N.: The EDGAR 3.2. Fast Track dataset (32FT2000). Documentation and datasets available at: http://www.mnp.nl/edgar/model/v32ft2000edgar/, 2007.
Wolke, R., Schröder, W., Schrödner, R., and Renner, E.: Influence of grid resolution and meteorological forcing on simulated European air quality: A sensitivity study with the modeling system COSMO-MUSCAT, Atmos. Environ., 53, 110-130, 2012.

Zhang, Y., Liu, P., Pun, B., and Seigneur, C.: A Comprehensive Performance Evaluation of MM5-CMAQ for the Summer 1999 Southern Oxidants Study Episode, Part III, Diagnostic and Mechanistic Evaluations, Atmos. Environ., 40, 4856-4873, 2006.

Zhang, Y., Wen, X.-Y., and Jang, C. J.: Simulating ClimateChemistry-Aerosol-Cloud-Radiation Feedbacks in Continental US using Online-Coupled WRF/Chem, Atmos. Environ., 44, 3568-3582, 2010.

Zhang, Y., Chen, Y.-C., Sarwar, G., and Schere, K.: Impact of Gas-Phase Mechanisms on WRF/Chem Predictions: Mechanism Implementation and Comparative Evaluation, J. Geophys. Res., 117, D1, doi:10.1029/2011JD015775, 2012a.

Zhang, Y., Karamchandani, P., Glotfelty, T., Streets, D. G., Grell, G., Nenes, A., Yu, F.-Q., and Bennartz, R.: Development and Initial Application of the Global-Through-Urban Weather Research and Forecasting Model with Chemistry (GU-WRF/Chem), J. Geophys. Res., 117, D20206, doi:10.1029/2012JD017966, 2012 b.

Zhang, Y., Sartelet, K., Wu, S.-Y., and Seigneur, C: Application of WRF/Chem-MADRID and WRF/Polyphemus in Europe - Part 1: Model description, evaluation of meteorological predictions, and aerosol-meteorology interactions, Atmos. Chem. Phys., 13, 6807-6843, doi:10.5194/acp-13-6807-2013, 2013. 